\title{
A oralidade e a busca dos efeitos de comicidade em Manolito Gafotas
}

\section{Renata Gonçalves Tavano}

Dissertação apresentada ao programa de Pós-Graduação em Língua e Literatura Espanhola e Hispano-Ameircana da Faculdade de Letras e Ciências Humanas da Universidade de São Paulo, para obtenção de título de Mestre em Letras.

Orientadora: Profa. Dra. Maria Zulma Moriondo Kulikowski

\author{
São Paulo
}


Aos meus pais, Ana Maria e José Tercino, que de forma simples me deram verdadeiras lições de sabedoria, e ao meu grande amor, Vinicius, pelo apoio incondicional, pelo carinho e pela atenção nos momentos de angústia. 
Agradeço à vida por mais essa oportunidade, à minha querida orientadora, Zulma, por sua paciência, pelas injeções de ânimo e principalmente pela confiança em mim depositada.

\section{RESUMO}

Apesar das diferenças existentes entre língua oral e língua escrita, ambas se interrelacionam; por isso são vistas por estudiosos da linguagem, como Briz e Marcushi, entre outros, como um continuum.

Sabe-se que nessas duas modalidades encontram-se tanto o registro formal quanto 0 informal. Dessa forma, seria errôneo, por exemplo, dizer que língua coloquial é o mesmo que língua oral, embora se reconheça que a coloquialidade está mais presente na modalidade 
falada que na modalidade escrita. Logo, de forma alguma a coloquialidade é exclusiva da oralidade.

Para se reconstruir um texto oral coloquial, portanto, é necessário não só lançar mão de um planejamento estilístico, como também empregar marcas próprias da oralidade e da coloquialidade, como expressões fixas, gírias, marcadores interacionais, entre outras.

A análise deste trabalho, por conseguinte, consiste em identificar e analisar tais marcas no corpus. Para comprovar a presença dessas marcas, além de facilitar sua visualização, elaboramos uma tabela

Outro elemento abordado nessa pesquisa, ainda que de forma incipiente, foi a questão da comicidade presente no corpus.

Assim, considerando a presença da oralidade/coloquialidade e da comicidade, este trabalho se propõe a verificar, a partir da análise da relação entre ambas, de que maneira a oralidade colabora para a produção do efeito de sentido cômico no texto.

Palavras chaves: oralidade; coloquialidade; comicidade; literatura, Manolito Gafotas 


\section{ABSTRACT}

In spite of the differences between oral and written language, both are interrelated, that is why they are seen by researchers as Briz, Marcushi and others like a continuum.It is known that in both modalities we can find as much formal as colloquial register. Because of this it would be wrong to say that colloquial language is the same as oral language, although we recognize that the informality is more present in the spoken modality than in the written one, by no means we can assert that informality only appears in the orality.In order to reconstruct an oral/ colloquial text it is necessary to use a stylistic planning and to make use of oral and colloquial aspects as: ready expressions, slang, signs of interaction and others. The analysis of our work consists of identifying signs of orality/ informality in the corpus. To prove the existence of these signs in our corpus we made a chart where it is possible to visualize them. Another feature that was slightly discussed in our research was the humor present in the corpus. Considering the presence of orality/ informality and humor, we tried to establish a relationship between both, or else, to show that orality also helped to a funny effect in the text. 


\section{SUMÁRIO}

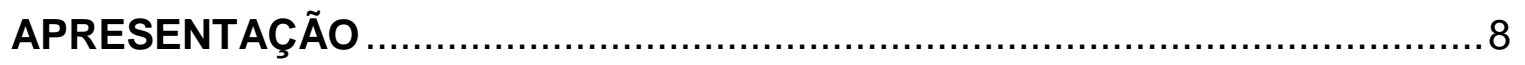

INTRODUÇÃO

\section{CAPÍTULO 1}

1 Manolito Gafotas: Um herói às avessas ..................................................12

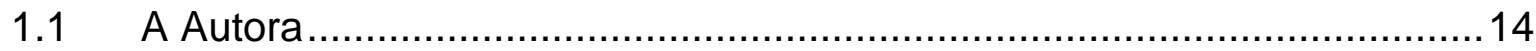

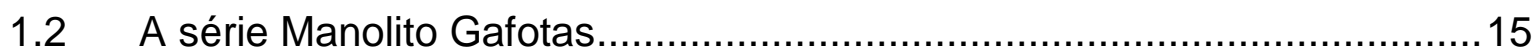

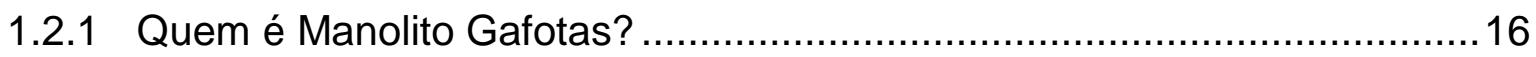

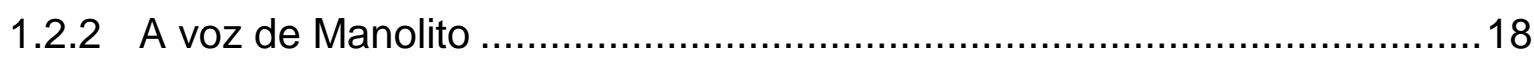

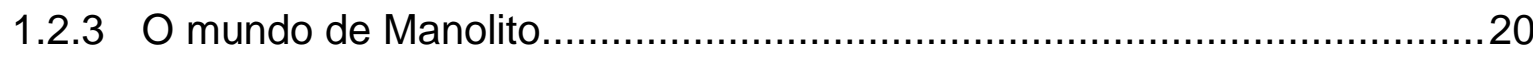

\section{CAPÍTULO 2}

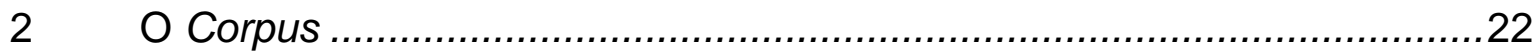

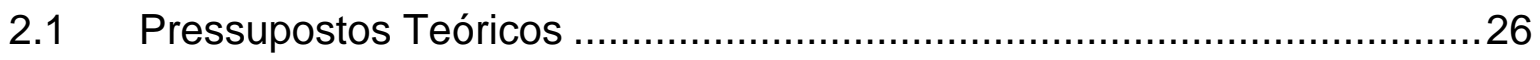

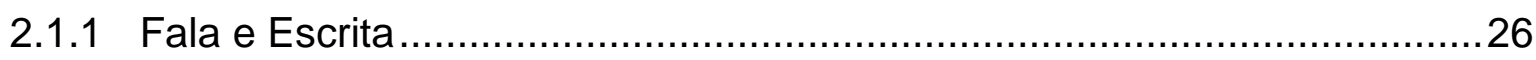

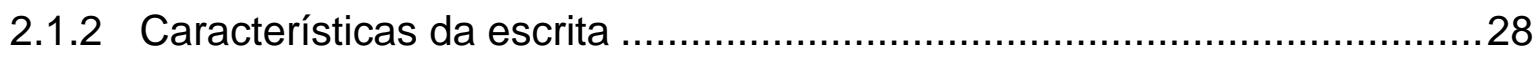

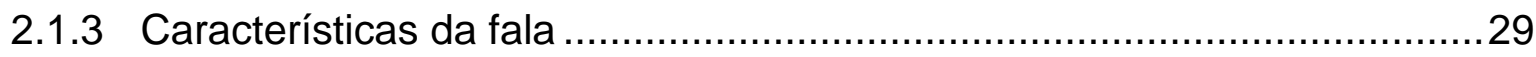

2.1.4 Estudos das diferenças..................................................................

2.1.5 Recursos para representar a fala na escrita ...........................................32

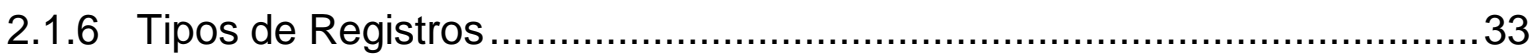

2.1.7 Língua, sociedade, interação pela linguagem.........................................36

2.2 Elementos que colaboram para a representação da oralidade no corpus

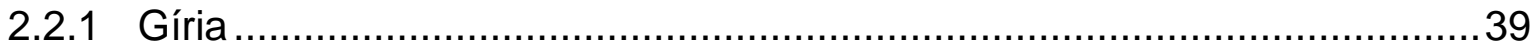

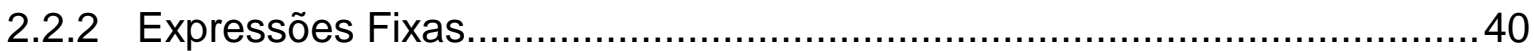

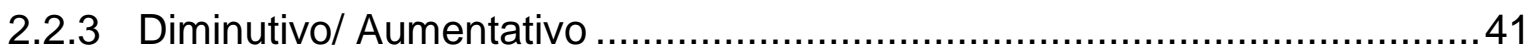

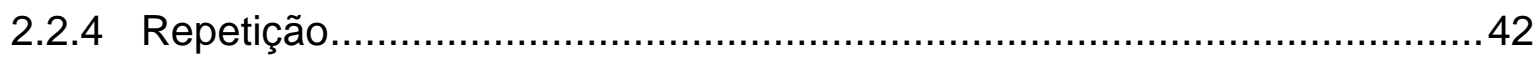

2.2.5 Reguladores conversacionais/Marcadores Interacionais........................ 42

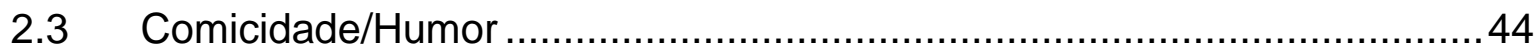

\section{CAPÍTULO 3}




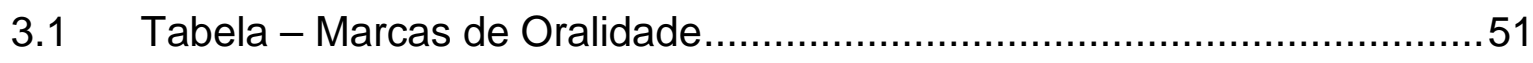

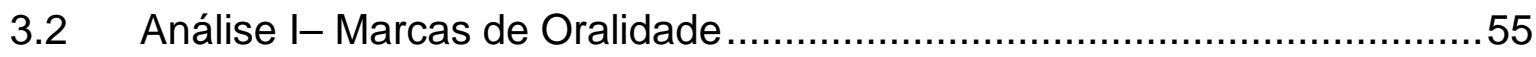

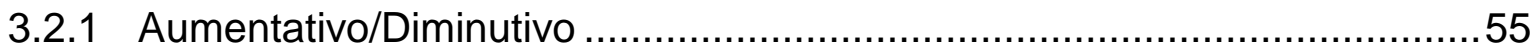

3.2.2 Reguladores Conversacionais/Marcadores Interacionais .........................57

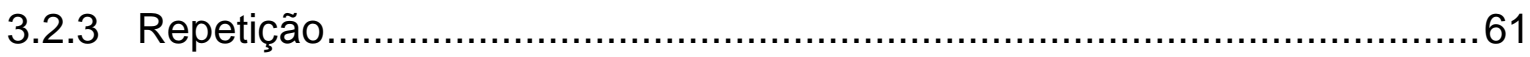

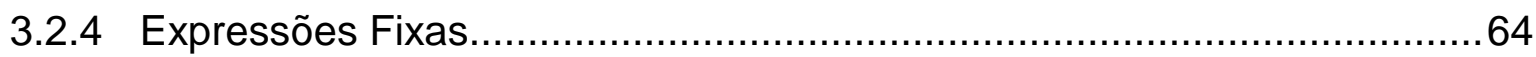

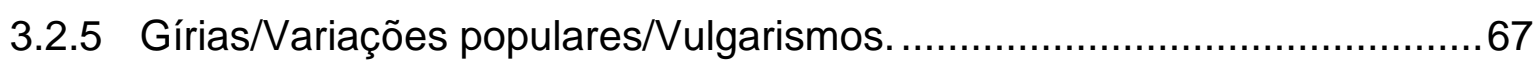

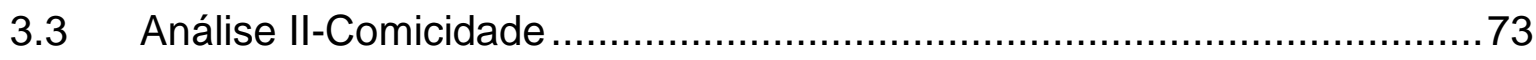

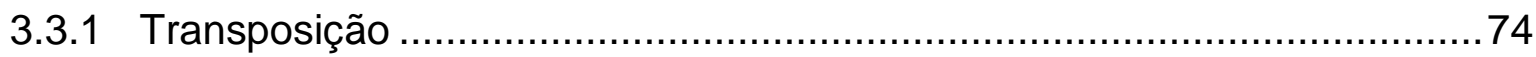

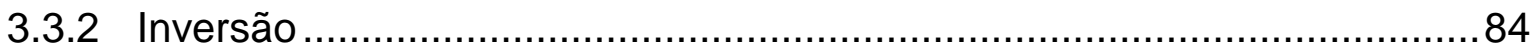

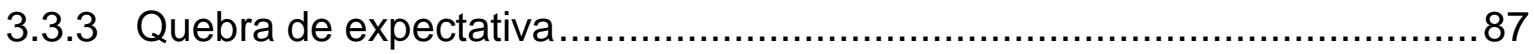

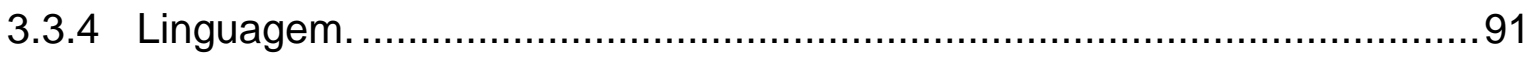

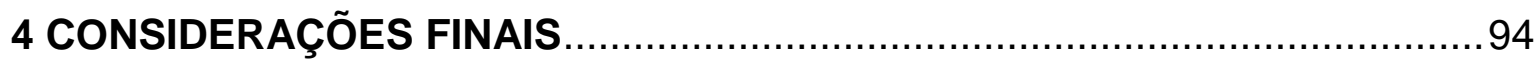

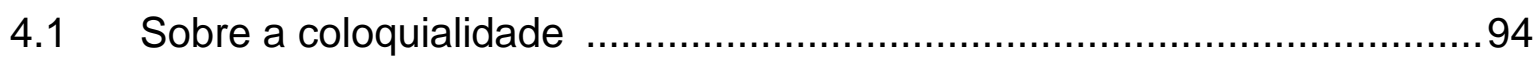

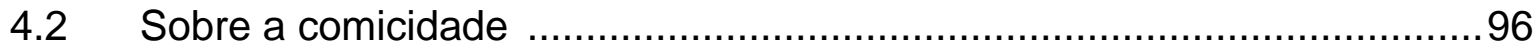

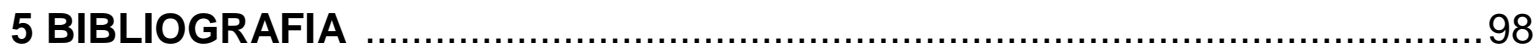

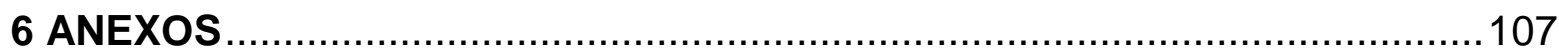




\section{APRESENTAÇÃo}

O interesse pelo tema surgiu a partir de uma curiosidade juntamente com uma necessidade. Durante o ano em que vivi na Espanha, realizei trabalhos com crianças. Pelo fato de elas apresentarem um vocabulário específico, muitas vezes não as compreendia, pois usavam gírias e expressões que a priori eu julgava estivessem relacionadas apenas ao universo infantil.

Fazia parte do meu trabalho ler histórias para elas e, entre suas histórias preferidas, estava Manolito Gafotas ${ }^{1}$. Diante da dificuldade de realizar a leitura, ou melhor, de compreender efetivamente o que eu lia, percebi que havia ali a presença de um léxico próprio, visto que para mim era quase incompreensível. Percebi que aquelas "falas" pertenciam à linguagem usada no cotidiano, ou seja, pertenciam ao registro informal. Diante disso, percebi que esse linguajar próprio só poderia ser "decifrado" com o contato contínuo e intenso com a língua espanhola e/ou através de perguntas feitas às próprias crianças, e assim o fiz.

Graças ou às explicações dadas por elas ou ao contexto em que o registro coloquial era empregado, sem desconsiderar ainda meu conhecimento de mundo, pouco a pouco fui me apropriando daqueles vocábulos, expressões e construções que até então me soavam estranhos.

Com o tempo fui percebendo que se tratava de histórias "sonoras", ou seja, histórias nas quais os personagens pareciam adquirir vida por meio da fala, pois nas histórias de Manolito havia um alto grau de informalidade presente nas falas dos personagens, o que permitia ao leitor maior aproximação com eles.

Hoje, tendo analisado o texto mais profundamente, posso afirmar que tal informalidade realmente está presente no texto, visto que a autora, Elvira Lindo, em entrevista ${ }^{2}$, afirma ter a intenção de representar de maneira "oral" a linguagem própria de um grupo. Por isso o leitor tem a sensação de escutar em obras dessa autora ecos de outras vozes que se mesclam seja às falas do narrador, seja às falas de outros personagens.

Somente após obter o domínio das expressões e as particularidades do registro empregado no corpus, é que pude perceber quão divertido é o texto. Diante disso, concluí que era impossível trabalhar somente os aspectos orais, pois havia percebido que os efeitos cômicos presentes, em grande parte decorrentes da oralidade, ganhavam relevância no conjunto da obra. Assim foi feito, ainda que de forma incipiente, pois se trata de um tema muito amplo, que uma dissertação não daria conta de abranger.

\footnotetext{
${ }^{1}$ Corpus (Manolito Gafotas, 1994)

${ }^{2}$ Ver biografia disponível em http://www.escritoras.com.es/elviralindo. Acesso em: 10 mai. 2004 (anexo).
} 


\title{
INTRODUÇÃO
}

\author{
"Faça as coisas de forma mais simples possível, porém não as \\ mais simples"
}

Albert Einstein

Este trabalho tem como objetivo analisar as marcas de oralidade/coloquialidade e seus efeitos de comicidade presentes no texto literário infanto-juvenil Manolito Gafotas (1994), da escritora espanhola Elvira Lindo. Selecionamos para análise seu último capítulo, Un cumpleaños feliz, por apresentar marcas de oralidade que se destacam no conjunto da obra e também por abordar uma temática universal, que atinge tanto adultos quanto crianças, agradando a ambos, que é a festa de aniversário.

Assim, no primeiro capítulo do nosso trabalho, procuraremos dar algumas informações, que julgamos relevantes para situar nosso leitor durante a analise, acerca da obra e de seu autor.

Pelo fato de o nosso corpus ser classificado como literatura infanto-juvenil, começaremos por um breve histórico da literatura infantil passando pelos comics, pois o personagem principal do nosso corpus foi publicado em tiras de um jornal espanhol de grande circulação: El País.

Ainda nesse primeiro capítulo, exporemos uma breve biobibliografia da autora, apresentaremos o personagem principal do nosso corpus, Manolito Gafotas, ressaltando suas características psicológicas e relacionando-o ao ambiente em que vive. Por fim, faremos uma descrição específica do próprio corpus.

No segundo capítulo, abordaremos os pressupostos teóricos que nos ajudaram a caracterizar alguns conceitos, tais como:

- oralidade/ coloquialidade

- elementos de oralidade na escrita

- efeitos de sentido humorísticos.

Para abordar os conceitos acima, tomamos como base os estudos de Briz (2000) referentes à oralidade/coloquialidade e sua caracterização, bem como a diferença entre oral e coloquial, os tipos de registro e os recursos empregados na reconstrução de um texto escrito com aspecto oral. Ainda nos apoiamos nos estudos de Marcushi (2001), para tratar da diferença entre fala e escrita, e, finalmente, na teoria de Bergson (1983), para trabalhar os efeitos de sentido cômicos.

No terceiro capítulo, apresentamos uma análise do corpus, acompanhada de algumas tabelas as quais permitem visualizar alguns dados relevantes para a compreensão do trabalho. 
Nessas tabelas encontram-se os elementos lingüísticos que colaboraram para o efeito de oralidade/coloquialidade no corpus .

No quarto capítulo, relacionaremos os dados encontrados nas tabelas com os efeitos de sentido produzidos no texto escrito, ou seja, analisaremos especialmente os elementos lingüísticos que colaboraram para o efeito de sentido cômico no corpus.

$\mathrm{E}$, finalmente, apresentaremos as conclusões das análises, a bibliografia geral e específica e os anexos.

Acreditamos que nosso trabalho possa colaborar tanto com os estudos relacionados à oralidade/coloquialidade quanto aos estudos dos efeitos de sentido humorísticos, nos textos infanto-juvenis, obtidos através do uso desse registro. 


\section{CAPÍTULO 1}

\section{Manolito Gafotas: um herói às avessas}

Ainda que sem a pretensão de nos aprofundarmos no tema da literatura infanto-juvenil, categoria na qual se encontra a obra Manolito Gafotas, não podemos deixar de caracterizar, mesmo que resumidamente, o universo da literatura infanto-juvenil.

Denomina-se literatura infanto-juvenil o conjunto de obras escritas, geralmente ilustradas, que são lidas por crianças. O gênero abrange desde clássicos da literatura mundial até livros quase sem texto verbal, compostos somente por ilustrações.

Nesse gênero, domínios discursivos como contos de fadas, fábulas e lendas, normalmente transmitidos pela tradição oral, e temas como a aventura, por exemplo, é que fazem desse universo literário uma dimensão mormente desejada e alcançada pela criança. Como se considera que literatura é um texto bem escrito cuja intenção primordial é atrair e "fisgar" o leitor, certamente um texto será caracterizado como pertencente à literatura infantojuvenil se parte dos leitores fisgados forem crianças, isso devido ao fato de apresentarem, além do tema e da estrutura simples, aspectos fantásticos e/ou maravilhosos, elementos que, indubitavelmente, atraem o universo infantil.

Coelho $(1985,113)$ caracteriza as narrativas literárias infantis como simples, com apenas um núcleo dramático do qual dependem os episódios que compõem a intriga.

A problemática é bem configurada e desenvolvida de forma que as ações se sucedem entre si, ou seja, apresenta uma natureza repetitiva. A linguagem também é marcada pela repetição a qual, muitas vezes, se apresenta como um elemento lúdico no texto, assim como as rimas e os jogos sonoros.

São repetidos os esquemas básicos, como os argumentos, os tipos de personagens, as funções dos personagens e os valores ideológicos. A reiteração desses esquemas na literatura infantil agrada aos leitores pelo fato de eles saberem previamente o que acorrerá.

A linguagem empregada nas produções literárias destinadas ao público infantil caracteriza-se pela simplicidade, uma vez que predomina o uso de vocábulos que estão mais relacionados a elementos concretos, e não o uso dos que estão relacionados a elementos abstratos. Em outras palavras, há um predomínio absoluto da figurativização. Vale destacar também que, nas referências, os dêiticos são evitados e, por conseguinte, a ordem direta (sujeito, ação, objeto) prevalece.

Muitos dos contos infantis "tradicionais" que conhecemos hoje foram transmitidos oralmente ao longo dos tempos. Devido à fugacidade da língua oral, eles foram sofrendo 
modificações, pois cada pessoa os contava à sua maneira - incluindo uma coisa aqui, extraindo outra ali -, às vezes de acordo com os interesses da época, daí boa parte essas histórias ter adquirido um cunho ideológico e moral. Apesar de tais modificações sofridas, a essência das histórias, entretanto, sempre permanece; e é graças a essa permanência que temos acesso a esses contos milenares.

As obras, por exemplo, dos irmãos Grimm e as do dinamarquês Hans Christian Andersen, tiveram um papel muito importante na formação da literatura infantil, pois eles recolheram os contos e os registraram, colaborando, dessa forma, para a "perpetuação" dos mesmos.

Com relação à grande aceitação dos contos de fadas, podemos dizer que, como decorrência dela, houve pelo menos duas conseqüências sobre a evolução da literatura infantil. Em primeiro lugar, impôs o predomínio do lúdico sobre o instrutivo. Em segundo, contribuiu para a definição de um gênero especificamente voltado para crianças.

No processo de formação da literatura infantil, a imprensa especializada teve grande importância, pois a partir de 1750 várias publicações infantis tiveram sucesso na Alemanha.

Entretanto, apenas no século XIX, que se iniciou a produção deliberada de literatura para o público adolescente. Destacam-se alguns romances históricos, como os de Walter Scott e Alexandre Dumas; obras de aventuras, como as de Charles Dickens - $A$ ilha do tesouro (1883) -; e as de ficção científica, como as de Júlio Verne - Viagem ao centro da Terra(1864).

Pelo fato de o personagem principal do nosso corpus ter sido representado em tiras do jornal espanhol El País, falaremos um pouco sobre o surgimento dos quadrinhos, que reúnem texto e imagens, e que também são conhecidos por cômics

No final do século XIX, tanto nos Estados Unidos como na Europa, os jornais recorriam a diferentes incentivos para atrair leitores. Com a modernidade dos sistemas de impressão, surgiram as páginas coloridas nos suplementos dominicais.

$\mathrm{Na}$ Espanha, as histórias em quadrinhos se popularizaram tanto quanto em outros países. Os comics espanhóis sugiram na revista TBO, e, por esse motivo, hoje são os chamados TEBEO ${ }^{3}$.

Durante os anos 50 e 70, os cômics foram bastante populares naquele país. Diferentemente dos heróis americanos, os "heróis espanhóis" pretendiam ser históricos, pois sutilmente tentavam retratar a situação sociopolítica daquele período.

Alguns personagens do cômics espanhol resistem bravamente, como por exemplo o Capitão Mortadela, enquanto outros estão em pleno auge, como é o caso de Manolito Gafotas, personagem do nosso corpus.

\footnotetext{
${ }^{3}$ TBO. Nome da revista na qual se publicaram os primeiros quadrinhos espanhóis e também nome que acabou sendo "emprestado" ao gênero e até hoje na Espanha os comics também são conhecidos como Tebeo (TBO).
} 
A história de Manolito começou em um programa radiofônico, passou pela tiras publicadas no jornal espanhol El País e hoje faz parte da literatura infanto-juvenil. Sua autora, Elvira Lindo, escreveu o primeiro volume das narrativas que têm como personagem principal Manolito em 1994, e, desde então, mais seis volumes foram publicados. Nas aventuras de Manolito, podemos perceber que sua vida não se resume a desgraças e violência, temas que costumam ser abordados quando se trata de representar o universo da classe social menos favorecida.

\subsection{A Autora}

Elvira Lindo nasceu em Cádiz, em 1962. Quando criança, gostava muito de ler, aos nove anos já havia lido todas os romances de Pearl S.Buck. Mujercitas e La Isla del tesoro são os mais interessantes para ela.

Aos doze anos, se mudou com sua família para o bairro madrileno de Moratalaz, por isso ela diz sentir-se madrilena.

A autora começou a trabalhar em rádio em 1987, como locutora, e logo se tornava especialista em roteiros, já que o mundo das informações não lhe atraía muito.

Manolito Gafotas, o protagonista de seus livros, nasceu nessa época, período em que ela foi convidada a fazer um programa na Radio Cadena, com pouquíssimo dinheiro. Elvira fazia paródias, piadas, inventava personagens, e, para representa-los, mudava de voz. Manolito Gafotas foi um dos personagens de que ela mais gostou de fazer; talvez porque estivesse deprimida, e, através desse personagem, podia dizer tudo o que queria. Portanto, Manolito, conforme a própria autora, "funcionou como uma válvula de escape".

Algum tempo depois, seu marido, Antonio Molina, percebeu que os roteiros formavam um mundo literário, e que era uma pena ser algo tão efêmero na rádio, convenceu Elvira a transformá-los em literatura

Lindo também escreveu um romance para adultos, El outro barrio (1998), além de roteiros para a televisão e para o cinema; para o teatro escreveu a famosa comédia de costumes La ley de la selva4.

\subsection{A série Manolito Gafotas}

Até o momento, Lindo publicou sete livros protagonizados por Manolito e um roteiro para o cinema, são eles:

Manolito gafotas. Madrid. Algafarra,1994.

¡Cómo molo! (otra de Manolito Gafotas). Madrid: Alfaguara, 1995.

Pobre Manolito. Madrid: Alfaguara, 1996.

\footnotetext{
${ }^{4}$ Por Luís García - disponível em http: www.eresmas.com.es (tradução feita por nós). Acesso em 20/10/2001.
} 
Los trapos sucios de Manolito Gafotas. Madrid: Alfaguara, 1997.

Manolito on the road. Madrid: Alfaguara, 1998.

Manolito Gafotas, 1998. (roteiro de cinema).

Yo y el imbécil. Madrid: Alfaguara, 1999.

Manolito tiene un secreto. Madrid: Alfaguara, 2002.

O primeiro livro protagonizado pelo nosso "herói" foi Manolito Gafotas (1994), do qual selecionamos para análise o seu último capítulo. Nesse livro, começamos a conhecer o garoto e a descobrir o seu mundo, nos inteiramos de que ele mora em um bairro obreiro de Madri, o Carabanchel Alto. O garoto também nos apresenta a sua família, amigos, vizinhos, a professora, enfim as pessoas que o cercam.

A narrativa apresenta uma sucessão de aventuras independentes e a única coisa comum entre elas são os personagens.

Os locais onde se passam as "aventuras" são os mais variados, ainda que todos relacionados ao seu universo, no qual se intercalam sua casa, o colégio, o Museu do Prado, o centro urbano e o seu bairro.

Quem narra as histórias é o próprio Manolito, portanto o interlocutor conhece somente perspectiva do narrador-personagem. Talvez, por esse motivo, quase sempre o leitor se torna seu "cúmplice", ou seja, o leitor se envolve na narrativa e torce por Manolito.

No decorrer da obra, nos é apresentado uma série de temas que envolvem a problemática pré-adolescente, como por exemplo as típicas brigas entre garotos e garotas, a insegurança após "levar um fora" de uma garota e as notas baixas no colégio, entre outros.

A temática certamente atrai muito os jovens leitores, pois além da identificação imediata em função do universo representado, tal universo é ainda permeado por uma linguagem simples, daí a identificação tornar-se ainda maior.

A narrativa também mostra as relações familiares, como o fato de Manolito sentir ciúmes de seu irmão mais novo ou de o avô ter que morar com a família por não ter condições de comprar uma casa própria; além de descrever coisas um tanto repulsivas, que as crianças em geral fazem, como, entre outras coisas, comer caca de nariz e competição de cuspe. Assuntos como esses, muitas vezes censurados pelos adultos, aqui são tratados com muita naturalidade, assim como as crianças e adolescentes os tratam.

O livro Manolito Gafotas (1994) começa com a apresentação que Manolito faz de si próprio, de sua família, de seu melhor amigo, Orejones Lopez, e de seu bairro (cap.1).

As aventuras vividas por ele se passam nas situações cotidianas, como em um passeio que faz ao centro com seu avô Nicolás (cap.2), na visita à psicóloga do colégio (cap. 3), o assalto que sofrem por parte de um jovem que veio da cidadezinha de seu avô (cap.5), o típico 
concurso de fantasias ocorrido no colégio, até a comemoração do aniversário de seu avô (cap10), o qual escolhemos para o corpus dessa pesquisa.

\subsubsection{Quem é Manolito Gafotas}

Segundo a própria autora, Elvira Lindo, criar um personagem não é fácil, sobretudo um personagem tão complexo e ao mesmo tempo tão simples, como Manolito Gafotas: simples, por se tratar de um garoto comum que estuda, tem uma família, vive certas aventuras corriqueiras etc.; porém complexo ao expressar-se, pois transmite vivências cotidianas com excelência, comove e também provoca o seu leitor, despertando nele não apenas riso, mas também reflexões mais profundas.

Com relação à construção do personagem, Lindo ${ }^{5}$ diz o seguinte:

Hay veces que crear un personaje cuesta mucho trabajo; uno hay que darle una edad, una ciudad, unos deseos, una historia que habitar; hay ocasiones, en cambio que son fáciles.

Porém no caso de Manolito, segundo a autora, a dificuldade foi pouca, pois é como se Manolito já existisse antes de estar no papel, por isso a relação dela com o personagem é muito mais que uma simples criação, é como se ele tivesse vida própria e ela apenas ouvisse suas histórias - "Parece que hubiera estado esperando en un banco del parque del Ahorcado a que alguien llegara para pillarle por banda y contarle su vida, la de sus amigos, la de su vecina la Luisa"*

Lindo diz escutar a Manolito há muito tempo, desde quando preparou um roteiro para ele na rádio onde trabalhava, inventando-Ihe uma voz; desde então, o personagem tomou uma proporção que a própria Elvira diz não reconhecer mais sua voz ao ouvir fitas antigas, mas sim ter a sensação de que ouve a um garotinho:

[...] no tengo la impresión de ser yo interpretando a un niño, sino de estar escuchando a un chaval de carne y hueso. Y esa voz de Manolito me acompañó a la hora de escribir sus aventuras. A veces me parecía como si él me fuera dictando. ${ }^{6}$

Talvez, pelo fato de o personagem ter nascido no meio radiofônico, nós leitores temos a sensação de estar ouvindo Manolito, apesar de a narrativas serem escritas. A própria autora diz que também o ouve ao escrever suas historias:

\footnotetext{
${ }^{5}$ Entrevista à revistra eletrônica disponível em www.escritoras.com.es/ mai/2000.

${ }^{6}$ Usamos apenas trechos da entrevista para confirmar nossas colocações, por isso a fala da autora se encontra "diluída" ao longo do nosso texto; os asteriscos, que a partir deste ponto serão utilizados, foi a melhor forma que encontramos para fazer referência a essa entrevista dada por Lindo.
} 
[...] no puedo hacer nada por evitar que se junte con Yihad, el chulito del colegio, me gustaría decirle que no jugara con él porque siempre sale perdiendo [...] pero no tengo que meterme en su vida, ni darle lecciones morales, ni avisarle de lo que está bien dicho o mal dicho $[\ldots]^{\star}$

Certamente, ao fazer todas essas afirmações, Lindo tenta expressar o quanto se envolve na história desse personagem, que, segundo ela mesma, às vezes, não é tão criança quanto pensamos, pois apresenta uma mistura de ingenuidade e maturidade, que lhe permite ser bastante perspicaz ao perceber seu entorno. Essa maturidade prematura do garoto faz com que identifiquemos muito sutilmente a presença de sua criadora. A própria autora afirma que essas marcas a traem como escritora e fazem com que o seu personagem se traia, pois se trata de um garoto que ainda não possui uma experiência de vida tão ampla, como se percebe na seguinte passagem: "[...] porque este niño tiene una mezcla de ingenuidad, lenguaje técnico [...] y sabiduría, que a mí me hace mucha gracia”*.

A autora também afirma que em sua infância era muito parecida como Manolito, e que, talvez por isso, tenha um repertório tão vasto para as aventuras protagonizadas por ele: "[...] Manolito se parece mucho a alguien que yo fui hace algunos años y que sigo siendo hoy a ratos, cuando me dejan."*

A obra de Lindo tem sido muito apreciada pelos críticos. De acordo com o jornal El país o valor de Manolito Gafotas está no fato de ser um garoto comum que vive sua discreta existência como se fosse um protagonista de grandes aventuras. Isso faz pequenos leitores se identificarem com ele, tornando-o, conseqüentemente, um herói, mesmo que não possua superpoderes nem inteligência notória, é como se fosse um herói às avessas.

\subsubsection{A voz de Manolito}

Elvira Lindo dá voz a seu personagem utilizando a primeira pessoa, o que possibilita, assim, que Manolito seja ele mesmo, pois, como suas características são bem definidas, é possível reconhecer sua "fala", de forma que produza no leitor a sensação de que é o garoto quem conta o que pensa ou sente, criando um efeito de verossimilhança.

A voz e autonomia de Manolito são tão evidentes que em um dos livros da série, a própria autora vai visita-lo e pede que lhe conte algo para que ela possa continuar escrevendo. Esse artifício usado é genial, porque se evidencia que Manolito tem a voz, Elvira apenas escreve.

7 El País, 04/01/1995. 
Por isso, a magnitude e o tom empregados por Manolito em suas "falas", a respeito de seu cotidiano, soa como se essas fossem as coisas mais importantes do mundo, como se percebe em: "No te lo vas a creer, pero creo que fue la tarde más feliz de mi $\square$ nalisa $\square \mathrm{a} \square$ en el planeta tierra." (Lindo op.cit, 134).

Assim, Manolito prende a atenção do leitor, ao expressar a criatividade lingüística existente nos garotos de idade parecida, que, assim como o personagem, criam suas próprias frases, as quais aos poucos vão se difundindo entre os grupos e passam a fazer parte da gíria infanto-juvenil.

Talvez a voz de Manolito seja tão explícita pelo fato de o personagem ter nascido na rádio, é como se após a autora ter lhe dado voz não fosse mais possível calá-lo. .

Manolito, às vezes, é bastante irônico, sarcástico, ainda que de maneira ingênua. Pelo fato de ser apenas um garoto narrando suas aventuras, não consegue distanciar-se delas, assim como fazem os adultos, e esse "não distanciamento" torna suas histórias mais vivas, pois, para o leitor, mesmo as narrativas apresentadas em um passado próximo parecem ocorrer naquele momento. Devido a riqueza de detalhes e a naturalidade apresentada, é possível, ao leitor, reconstruir visualmente a cena.

A proximidade comunicativa sugere um grau de intimidade entre os interlocutores, na medida em que o narrador parece acreditar que há um conhecimento mútuo, e, confiando nisso, se expressa livremente conferindo ao discurso mais espontaneidade.

Por ser Manolito um garoto de Madri e morar em um bairro pobre, domina a linguagem periférica de um grande centro, ou seja, domina a linguagem de seu universo social e de forma coerente com esse universo trata de expressa-la

Considerando o contexto criado, a informalidade predominará na narrativa e será transmitida principalmente através da linguagem do narrador/personagem, que, ao se expressar, "constrói" um interlocutor a quem trata por tu; esse tipo de tratamento não só cria uma aproximação entre ambos, mas também insere o leitor no universo informal da narrativa.

A forma de tratamento empregada por Manolito é um recurso muito interessante, já que a partir dele se instala uma proximidade entre ambos os interlocutores, sem levar em conta a idade, prestígio social, entre outras variáveis, o que indica que o personagem poderá continuar a se expressar de maneira coloquial, pois quanto maior for grau de intimidade mais a coloquialidade se faz presente no discurso.

Para que houvesse essa naturalidade e espontaneidade da oralidade/coloquial, para finalizar, a autora fez um planejamento estilístico verbal, recriando a suposta naturalidade empregada em uma conversação real, por isso se percebe o uso adequado de determinadas estratégias léxico-discursivas cuja finalidade fosse a representação da oralidade/coloquialidade em um texto ficcional escrito. 


\subsubsection{O Mundo de Manolito}

Com já dissemos anteriormente, é fácil o leitor se identificar com Manolito. Entre tantos possíveis motivos, inclusive alguns já até mencionados, um que merece ser destacado é o fato de que grande parte de seus leitores também pertence a uma classe social que passa pelas mesmas dificuldades vividas pelo nosso protagonista, ou seja, são crianças e adolescentes que também não viajam quando estão em férias, pois, assim como o personagem, vivem no interior do país (Espanha) e que quase nunca vêem o mar devido à distância. Com relação aos que não pertencem a esse universo, o mesmo não the é de todo estranho, ou seja, de alguma forma é possível reconhecer o mundo do personagem.

Para Manolito, a família representa o centro do seu universo, em segundo lugar, o colégio "Diego Velazquéz", logo depois o bairro periférico, que, apesar dos problemas para o garoto, parece ser o melhor lugar do mundo.

Assim como para a maioria das crianças, para Manolito as coisas mais importantes também são as cotidianas, como as celebrações do bairro, brincar no Parque Árbol del Ahorcado, o dia de Reis, o Natal, as férias de verão e os amigos, que, para o ele, são preciosíssimos.

A valorização do cotidiano como único mundo possível está representada pelos recortes lingüísticos (registro, socioleto, gírias) que limitam o universo da personagem a um ambiente reduzido, que abarca apenas o lar, a escola, o bairro e os contatos com os amigos. São contextos em que a compreensão dessa linguagem é imediata.

Os referentes textuais também limitam a narrativa aos espaços marginalizados, produzindo uma leitura simples e direta. Talvez seja essa objetividade uma das razões pelas quais essa obra é considerada literatura infanto-juvenil. 


\section{CAPÍTULO 2}

\section{Corpus}

O corpus dessa dissertação consiste no último capítulo - Un cumpleaños Feliz - do primeiro volume da série Manolito Gafotas ${ }^{8}$, escrito por Elvira Lindo.

O corpus é vasto naquilo que se refere aos diferentes aspectos lingüísticos, uma vez que apresenta desde uma narrativa que reconstrói a oralidade/coloquialidade, bem como apresenta questões de comicidade, as quais, em concordância com Baktin (1997), podemos dizer que são usadas como instrumento de transgressão não só são contra determinados valores ideológicos, mas também na luta contra a lógica da linguagem em torno da qual aqueles mesmos valores se organizam.

A história apresentada no corpus vai da página 118 à 134. Toda a ação se passa de um dia para o outro, e seu desenrolar começa na casa de Manolito, que fica no bairro Carabanchel Alto, quando a mãe propõe ao avô do garoto uma festa para comemorar os seus 80 anos. Como ele se mostra relutante à idéia, ela, de maneira muito bem articulada, planeja uma festa surpresa.

$\mathrm{Na}$ escola, Manolito se lembra de que seu avô havia dito que não gostaria de ter uma festa cheia de amigos velhos, então o garoto imagina que o avô não se importaria se ele convidasse os seus amigos, afinal eram crianças. Feito o convite, obviamente todos aceitaram.

A tarefa de Manolito, agora, era comprar um presente para o avô com algumas míseras moedas, que, como são poucas, ele justifica dizendo que só havia economizado o dinheirinho de apenas um final de semana. O mais interessante, no entanto, é que, mesmo com tão pouco, ele consegue um comprar um presente surpreendente.

Por se tratar de uma festa surpresa, a mãe teve de arranjar uma desculpa para tirar o avô de casa e assim seguir com seu plano. Como o irmão de Manolito, Imbecil, está sempre doente, ela pede ao avô que o leve ao médico. Ele aceita sem desconfiar de nada.

No consultório, enquanto esperam o médico, Manolito e seus amigos fazem muitas travessuras, até levam uma bronca do próprio Dr. Morales.

Após a consulta, todos se dirigem para a casa de Manolito e fazem a surpresa a Don Nicolas, que se emociona muitíssimo, afinal só dissera que não queria a festa, da boca pra fora.

O desfecho da história ocorre na casa onde tudo começou, porém a história se finaliza no parque do bairro Carabanchel Alto. Os espaços da narrativa se restringem ao bairro, é ali

\footnotetext{
${ }^{8}$ LINDO, Elvira. Manolito Gafotas.. Madri: Algafarra, 1994. ( tomamos como referência a $30^{\mathrm{a}}$.impressão desta edição).
} 
que tudo acontece, pois no bairro vive sua família, os seus amigos e é onde está a escola, enfim é o único universo que conhece, onde, inclusive, todos se identificam pelo seus costumes, calores e linguagem.

Observamos que a história se inicia na casa, logo que amanhece o dia. Depois segue, exatamente nesta ordem: no colégio, no posto médico do bairro, no bar da esquina e novamente na casa, completando um ciclo. Vemos que, no mesmo espaço que houve divergência por conta de o avô não querer a festa, houve também a alegria proporcionada pela festa, assim o elemento festa proporcionou dois tipos de emoção que se contrapõem.

Para finalizar a narrativa, a autora proporciona ao leitor a "visão" da cena, através da narração de Manolito, que a descreve minuciosamente. Sentados em um dos poucos bancos inteiros do parque, o pequeno Imbécil dorme com cabeça no colo do avô e os pés em Manolito, que apreciam o pôr-do-sol, o qual, segundo eles, é o mais bonito do mundo. Nessa cena há um "acontecimento mágico", pois em pleno mês de abril, no bairro Carabanchel Alto, o sol se põe tarde como se estivessem no verão. Para dar veracidade à cena, Manolito diz que os cientistas não conseguem explicar o porquê de o verão, no Carabanchel Alto, começar no dia do aniversário de seu avô.

Os personagens presentes no corpus são os seguintes: narrador/personagem Manolito, sua mãe, que não é identificada pelo nome no corpus (assim como no resto da obra), seu irmão caçula apelidado de Imbecil, seu avô Don Nicolás, a professora Sita Assunción, o pai Manoel Garcia Moreno, os vizinhos Luisa e Bernabé, os amigos do avô, os amigos de Manolito (Orejones Lopez, Paquito Medina e Yihad), o dono do bar Sr. Ezequiel e o Doutor Morales. Na narrativa, todos os personagens citados têm "voz", ou seja, todos se expressam, seja por meio do discurso indireto, seja por meio do discurso direto, encontramos ainda alguns poucos discursos diretos livres.

Embora não tenhamos explorado esse aspecto de forma contundente, pudemos observar que os discursos diretos e os indiretos se apresentam praticamente na mesma proporção, sendo que a maior parte dos discursos diretos pertence ao avô.

O uso do discurso direto garante maior realidade ao texto, assim, ao encontrar esse tipo de discurso na narrativa, o leitor tem a sensação de estar "ouvindo" exatamente o que determinado personagem disse, visto que não há a voz de um narrador que fale por ele.

Porém, a fim de não tornar o texto cansativo e aproxima-lo de uma situação real, o narrador intercala ao discurso direto o discurso indireto, pois, quando nos expressamos oralmente, fazemos uso dessas duas formas de discurso.

A pessoa que mais tem "voz" no texto, além de Manolito, que narra a história, é seu avô, depois sua mãe. Já seu pai, se expressa apenas uma única vez, mesmo assim, através do discurso indireto; o irmão não se expressa nunca, é como se Manolito não lhe desse esse 
direito, assim como os vizinhos, que também não se expressam; já os seus amigos, têm sua voz citada por Manolito, por meio do discurso indireto. Talvez, o fato de os personagens terem "voz" ou não esteja relacionado a seu papel social e afetivo dentro da narrativa.

Parece-nos que o avô é privilegiado nesse sentido, pois se expressa livremente, diz o que quer e quase sempre Manolito o cita literalmente, ou seja, utilizando-se do discurso direto, o leitor tem acesso à fala do avô. Acreditamos que a liberdade conferida ao avô se deva aos seguintes motivos: o vínculo afetivo entre Manolito e ele é bastante grande, pois as atitudes do avô mais se parecem com as de uma criança, daí a identificação entre eles; o outro fator que é determinante para que Don Nicolás fale tão livremente, no caso de nosso corpus, é o fato de ser seu aniversário, portanto, nesse dia, ele deve ter certas regalias, principalmente porque, de fato, ele é o protagonista.

A mãe tem sua fala garantida, pois, apesar das broncas, Manolito a considera perfeita.

Já o pai, quase não se expressa, já que, segundo o narrador, ele é bastante ausente devido à profissão de caminhoneiro. A menção sobre a profissão do pai, feita pelo garoto, talvez possa simbolizar tanto a ausência física quanto a ausência afetiva.

O irmão de Manolito não tem o direito de se expressar, talvez porque Manolito morre de ciúmes do irmão pelo fato de ser o caçula. Assim, ele, o narrador, "rouba" sua fala.

Os amigos se expressam pouco, e quando isso acontece é principalmente por meio do discurso indireto, é como se pelo menos ao contar a história, Manolito tivesse o poder de censurar seus amigos, restringindo suas falas; afinal, esse é o único momento em que ele detém o poder.

Lembremos que todos os personagens se expressam da mesma forma, ou seja, coloquialmente, usam as mesmas expressões, portanto se identificam lingüisticamente, o que é bastante coerente, uma vez que todos pertencem ao mesmo universo sociocultural. Logo, as gírias, frases feitas e expressões idiomáticas são empregadas por todos. Quanto aos jogos sonoros, são empregados apenas pelos personagens infantis.

Explorando a linguagem coloquial, o personagem reconstrói um universo que proporciona a interação com seu leitor. Para aproximar-se dele, Manolito o trata por tu, estabelecendo, assim, a interação. A interação proposta fica evidente nos momentos em que Manolito ou apela ao leitor para que esse adivinhe o presente que ele havia comprado ao seu avô ou quando responde a possíveis perguntas do leitor.

O mundo lingüístico dos personagens do corpus se limita ao empregado por eles na narrativa, que é o registro coloquial. Há, porém, uma passagem da narrativa em que Manolito faz uso da expressão latina ipso facto. Como sabemos que o seu domínio cultural não é muito amplo, pois é apenas um garoto, o uso da expressão parece inadequado dentro do contexto 
criado. Julgamos, entretanto, que ela serviu para Manolito tentar impressionar o seu leitor, ainda que seu uso acabasse produzindo um efeito cômico no texto.

Baseando-nos nos conceitos da sociolingüística, vemos que o registro informal, empregado pelo personagem, é perfeito, visto que se trata de um garoto que narra situações cotidianas, portanto situações sem nenhum tipo de tensão.

Por representar um texto oral em uma situação de familiaridade, a espontaneidade e a idéia de um discurso planejado simultaneamente à sua execução, ou seja, produção imediata, são itens que revelam um alto nível de elaboração por parte da autora, que se vale de todos esses elementos do discurso oral/coloquial e nos dá a "ilusão" de um texto oral condizente com o contexto criado.

As expressões "ditas" por Manolito podem mostrar aspectos sociais e de sua época, viso que ele utiliza expressões atuais empregadas normalmente por jovens e crianças, o que revela o universo em que vive, como por exemplo, seu bairro e seu colégio.

O corpus apresenta uma questão muito interessante com relação aos nomes dos personagens, ou à falta deles. Todas as crianças possuem apelidos e esses tratam de evidenciar os "defeitos" dos personagens. Comecemos pelo nosso protagonista Manolito Gafotas, seus amigos Paquito e Orejones, seu irmão Imbecil e sua mãe, que não tem seu nome revelado; exceto Don Nicolás e seu pai Manoel, todos os outros parecem, portanto, estar em um nível de menor importância, principalmente por terem seus nomes transformados em apelidos depreciativos.

O corpus também apresenta efeitos de comicidade ora causado pelas situações apresentadas, ora pelos próprios recursos lingüísticos.

Para que se compreenda esse efeito de sentido texto, caberá ao leitor inferir algum conhecimento e deduzir o significado de algumas expressões, pois o texto é bastante conotativo.

A falta de percepção dos registros empregados por parte de Manolito, em toda e qualquer situação, cria um humor "quase constrangedor", pois rimos da ingenuidade do personagem, além das situações apresentadas que criam uma sensação incômoda.

\subsection{Pressupostos Teóricos}

Tendo escolhido para corpus desta pesquisa um texto que "reconstrói" a oralidade, pretendemos analisar o caráter mais relacionado à língua que à literatura, bem como analisar de que maneira as questões de humor, apoiadas na oralidade, se apresentam nesse texto. Para tanto, recorremos a teóricos que estudam a comicidade, além recorrermos a teóricos que apresentam conceitos referentes a questões de língua e oralidade. 


\subsubsection{Fala e Escrita}

Como sabemos, para nos comunicarmos, dispomos de duas modalidades lingüísticas mais significativas; são elas: a fala e a escrita. Ambas fazem parte do mesmo sistema, no entanto, sua realização, bem como sua produção, apresentam algumas diferenças.

A primeira se realiza por meio de um sistema sonoro e a segunda de um sistema gráfico. Inclusive as crianças sabem da existência dessa diferença, pois mesmo as que não sabem ler, ao pegarem um livro e fingirem lê-lo, usam entonação diferente e fazem uma seleção de vocábulos normalmente pouco utilizados na sua fala.

Com relação à conceitualização, Marcuschi (2001, p. 25-26) afirma que:

A oralidade seria uma forma social interativa para fins comunicativos que se apresenta sob variadas formas de gêneros textuais fundados na realidade sonora; ela vai desde a realização mais informal à mais formal nos mais variados contextos de uso.

[...]

A fala seria uma forma de produção textual discursiva para fins comunicativos na modalidade oral (situa-se no plano da oralidade, portanto), sem a necessidade de uma tecnologia além do aparato disponível além do próprio ser humano. Caracteriza-se pelo uso da língua na sua forma de sons sistematicamente articulados e significativos, bem como aspectos prosódicos, envolvendo, ainda, uma série de recursos expressivos de outra ordem, tal como a gestualidade, os movimentos do corpo e a mímica.

A escrita seria um modo de produção textual-discursiva para fins comunicativos com certas especificidades materiais e se caracteriza por sua constituição gráfica, embora envolva também recursos de ordem pictórica e outros (situa-se no plano dos letramentos).

Com relação ao processo de aquisição dessas modalidades, podemos afirmar que a língua falada é patrimônio de todos, é adquirida espontaneamente e que é através dela que o homem entra em contato com o mundo e interage com seus semelhantes. Assim, tanto sua aquisição quanto sua manifestação se dão em um processo natural de comunicação.

Já a escrita, pertence apenas aos que se submetem ao sistema de letramento, e por esse motivo alguns, erroneamente, a consideram superior, uma vez que a escrita geralmente indica uma sociedade culturalmente "mais desenvolvida".

Contudo, a língua escrita revela mais espontaneidade e vivacidade justamente quando incorpora os fenômenos típicos da linguagem falada, que, por sua própria natureza, apresenta mais recursos expressivos.

Sobre essa complementaridade entre fala e escrita, Marcuschi (op. cit., p. 16) afirma: 
Hoje [...] predomina a posição de que se pode conceber oralidade e letramento como atividades interativas e complementares ao contexto das práticas sociais e culturais.

Uma vez adotada a posição de que lidamos com práticas de letramento e oralidade, será fundamental considerar que as línguas se fundam em uso e não ao contrário. Assim não serão primeiramente as regras da língua e nem a morfologia merecedores de nossa atenção [...]

\subsubsection{Características da escrita}

$\mathrm{Na}$ escrita, existe a preocupação formal que requer técnica no seu uso, para que a comunicação realmente ocorra, pois não conta com os recursos extralingüísticos de que a fala dispõe, por isso o conteúdo que se expressa deve ser minuciosamente explicado. Conseqüentemente, essa modalidade apresenta uma maior elaboração das informações, o que implica o uso de uma sintaxe mais complexa.

Nesse sentido, os dêiticos e as anáforas são freqüentemente substituídos por reiteração textual, pois essa forma de retomar o referente permite que o leitor não se perca no texto, uma vez que o referente pode estar distante e o contexto não possibilite que o leitor o identifique com precisão. Não obstante, para que o texto não se torne cansativo, as reiterações de referentes podem ser feitas por meio de sinônimos e paráfrase, entre outros recursos de coesão.

Com relação ao léxico, na escrita, ele se apresenta mais amplo e variado, assim como as estruturas que também podem aparecer de forma variada. $O$ emprego das variações é possível, uma vez que o leitor dispõe de tempo para decodificar o texto e pode voltar a ele quantas vezes forem necessárias para a sua compreensão.

$\mathrm{Na}$ escrita, as letras se apresentam em um suporte fixo e estável que permite captar todos os signos de maneira simultânea e por meio do qual o leitor poderá determinar o ritmo da leitura de acordo com a sua necessidade de compreensão.

Destarte, a comunicação escrita não permite interação direta ${ }^{9}$, visto que apenas se pode imaginar a reação do leitor. Portanto, o enunciador não pode modificar seu discurso baseandose nessa interação, embora haja nessa modalidade da língua a possibilidade de corrigir, retirar ou acrescentar informações quantas vezes o enunciador achar necessário.

Como a manifestação da fala se difere da manifestação da escrita, certamente seus processos de elaboração também, por isso, com relação ao planejamento, Urbano (2000: 87) explica:

\footnotetext{
${ }^{9}$ Atualmente, as novas tecnologias, como o "chat" de internet, estão mudando, de certa forma, esse modo de ver a interação na escrita
} 
Talvez a questão mais importante a ser considerada quanto ao modo de produção do texto falado seja a questão da simultaneidade do pensamento e expressão em relação à defasagem que, nesse sentido, ocorre na produção do texto escrito. Por força dessa produção, o texto falado brota bruto, revelando na sua superfície esse caráter emergente, isto é, explicitando os processos da sua própria criação/construção. Trata-se de uma execução única, sem revisão e apagamento possível [...] Em se tratando de texto escrito, o escritor planeja, às vezes até por dias, o texto.

Dessa forma, vemos que o autor tem a oportunidade de obter mais informação e pensar, podendo organizar-se lingüisticamente em busca de estruturas e léxico que atendam, adequadamente, aos seus objetivos.

\subsubsection{Características da Fala}

Sabemos que a fala, ao contrário do que se pensava, não é desorganizada nem fragmentada, mas sim apresenta uma organização própria que os falantes aprendem com o uso.

Na organização textual da fala, a comunicação é imediata, por isso se usa uma sintaxe pouco complexa, com períodos curtos, frases incompletas (suficientes para a compreensão e que se interrompem quando isso acontece) que permitem tanto ao falante quanto ao ouvinte processarem a informação mais facilmente. Como recursos mais presentes nessa modalidade, merecem destaque: anacolutos e elipses, hesitações, repetições e paráfrases, sobreposição, freqüência de construções impessoais com fundo atenuador, bem como o uso de "muletilhas", ou marcadores conversacionais, além dos dêiticos que assumem significados dependendo de quem fala, quando fala e de onde fala.

$\mathrm{Na}$ fala, as frases são mais curtas, com excessiva coordenação, os enunciados se relacionando praticamente sem conectores explícitos ou com poucos conectores simples, além de elementos prosódicos. Essa modalidade lingüística costuma utilizar a ordem básica da língua: sujeito, verbo e complementos, ainda que essa ordem não seja fixa.

Quanto ao léxico, as palavras e expressões são usadas com significado específico, entretanto, os termos com sentido figurado são utilizados sempre que se deseja criar um efeito metafórico.

Com relação à referência, na fala, os dêiticos se apresentam com freqüência, pois o referente quase sempre está próximo aos interlocutores ou o próprio contexto trata de evidenciá-lo - ou ainda pode-se contar com os recursos extralingüísticos, como gestos, por exemplo.

Para estar seguro de que o que está sendo dito está sendo compreendido, na fala, há uma tendência a repetir ou parafrasear o que foi dito, visto que seu ouvinte não pode recuperar 
o texto quando queira, dessa forma se garante que o interlocutor capte a informação essencial. Por essa razão, a língua oral tem como característica a repetição de estruturas e utiliza um léxico mais limitado. Segundo Alcoba (1999), são recursos da fala: o uso de conjunções simples, reguladores conversacionais, expressões idiomáticas, algumas com marcadas sociodialetal, gírias, reguladores enfáticos e outros; lembremos que as gírias e as expressões normalmente são empregadas em situações mais coloquiais e que nem toda fala é coloquial.

A imediatez da oralidade permite a interação direta, o falante pode perceber a reação do ouvinte e modificar seu discurso, ao mesmo tempo em que o ouvinte pode guiar o falante na estruturação do discurso. Para que ocorra essa reestruturação imediata, é necessário que se tenha um controle do que está sendo tratado, haja vista o fato de que não se pode apagar o que foi dito, apenas retificá-lo.

A construção do sentido é fruto de uma colaboração, co-elaboração, em que cada um dos interlocutores atua sobre o outro como em um jogo. São as interrupções, os cortes, tão comuns na conversação natural, que dinamizam esse jogo, entendido como um espaço onde a complementaridade das idéias visa o entendimento do texto; daí se falar em uma colaboração mútua.

Também merecem destaque os traços prosódicos e extralingüísticos, pois importantíssimos na fala, podem dar coerência ao texto ou reforçar idéias, como, por exemplo, é o caso da entonação e das pausas, que, muitas vezes, servem para que o falante possa reestruturar o que vinha sendo dito.

Esses traços carregam em si muitas informações que podem, inclusive, indicar o estado emocional do falante, dependendo do tom empregado por ele. A gestualidade, por exemplo, como o movimento afirmativo com a cabeça, pode indicar se o texto está interessante ou até mesmo monitorar o falante para que ele prossiga ou mude o seu discurso.

\subsubsection{Estudos das diferenças}

A diferença existente entre fala e escrita não indica que uma seja superior à outra; de acordo com Marcuschi (2001), devemos considerá-las sistemas paralelos, sistemas cognitivos complementares, sem nos esquecermos de que além dessas duas modalidades existem os graus intermediários.

Há muitos estudos que analisam as diferenças existentes entre fala e escrita. Entre eles, há alguns lingüistas como Halliday, Ochs (apud MARCUSCHI, op. cit., p. 27) que acreditam que fala e escrita devem ser analisadas na perspectiva das dicotomias.

Esses teóricos afirmam que a fala é contextualizada, dependente, implícita, redundante, não planejada, imprecisa, não normatizada, fragmentada, ao contrário da escrita, que é descontextualizada, autônoma, explícita, condensada, planejada e normatizada. 
Essa perspectiva falha ao colocar a fala como "não-normatizada" e "fragmentária" e a escrita como "normatizada" e "completa". Dentro das suas condições de produção, a fala tem suas próprias normas, e o fato de ela apresentar uma sintaxe mais solta não significa que é fragmentária, pois o próprio contexto, os gestos e as feições complementam o discurso.

É importante ressaltar que essa visão já está superada justamente por ser falha, e hoje essas duas modalidades não são mais estudadas na perspectiva da dicotomia, mas sim na perspectiva de continuum, visto que elas se interagem e se complementam (MARUSCHI, 2001; URBANO, 2000; BRIZ, 1998).

\subsubsection{Recursos para representar a fala na escrita}

Ainda que utilizemos os recursos de pontuação, a riqueza de matizes da língua oral não permite que sua representação escrita seja perfeita, pois tais recursos não dão conta de explicitar tudo o que se deseja.

Sabemos que, quando se produz um discurso, não só a escolha lexical é fundamental, como também tal escolha deverá basear-se no contexto situacional real. Especificamente do nosso corpus, o que se deseja é reconstruir uma situação coloquial expressa pela imitação da oralidade, para tanto a autora criou um universo textual que possibilitasse tal reconstrução.

Portanto, penetramos no universo do narrador/personagem através da linguagem, pois é por meio dela que ele expressa o seu "real cotidiano". Essa realidade se faz presente principalmente devido a usos próprios da linguagem coloquial falada incorporados no texto escrito literário. Tal incorporação colabora para tornar o texto mais dinâmico e real, conseqüentemente menos vinculado à gramática normativa.

Como relação a essa incorporação de aspectos da oralidade na escrita, Alcoba (op. cit., p. 22) coloca que:

[...] usar expresiones típicas de habla pueden muchas veces parecer pobreza vocabular, cuando en realidad es el empleo, en la lengua escrita, de la naturalidad de la língua hablada.

[..]

Podemos tratar los mismos temas con el habla o con la escritura, y como hemos señalado, utilizar los distintos grados de formalidad o familiaridad en ambos medios. Lo importante es que al usar un medio de comunicación u otro tengan en cuenta las características próprias del modo de produción de cada uno, y se seleccionen los rasgos linguísticos más adecuados. 
Assim, vemos que não podemos pensar na língua escrita sem pensar na língua falada, porque é como se uma fosse extensão da outra e ambas se complementassem; por esse motivo, é difícil fazer uma distinção rígida entre elas. Temos, por exemplo, os programas televisivos que são escritos para serem falados, e que, por isso, apresentam uma gramática mais livre, menos normativa; por outro lado, temos, como exemplo, as palestras científicas que são faladas, porém estão bastante vinculadas às normas gramaticais e à formalidade; além desses exemplos, temos os chats na internet. Portanto, devemos considerar esses níveis intermediários, pois eles reforçam a reciprocidade entre fala e escrita.

Sobre o uso de uma gramática mais livre Preti (1974: 55) afirma que:

Os escritores românticos foram os primeiros a reagir sobre a tirania da gramática, opondo-se ao "purismo" arcádico com um estilo que pretendia mais coloquial. Quase todos receberam uma influência decisiva do estilo das redações de jornais, pelas quais, invariavelmente, passaram e onde se impregnaram da linguagem do dia-dia da imprensa.

No corpus analisado, percebemos a influência da língua oral na língua escrita, pois encontramos construções próprias da língua falada, como os procedimentos e recursos que podem fugir à norma padrão incorporados a um texto escrito.

\subsubsection{Tipos de Registros}

A comunicação oral e a comunicação escrita além de apresentam o mesmo sistema lingüístico, ainda podem se utilizar tanto do registro formal quanto do informal. Entretanto, as realizações são diferentes, pois o uso de um ou de outro dependerá do contexto, cabendo ao enunciador, portanto, adequar o tipo de registro à situação. Não devemos nos esquecer também de que o domínio dos registros está relacionado ao nível sociocultural e que há pessoas que, dominando apenas o registro informal, terão produções predominantemente informais, tanto em sua produção oral quanto escrita.

Para que nosso leitor possa compreender melhor nossa investigação, acreditamos fazer-se necessário apresentar alguns conceitos - registro formal e registro coloquial (informal), popular e vulgar - para que possamos seguir com maior clareza.

Para que não ocorram equívocos com relação à palavra coloquial, pois ela pode remeter a colóquio, o que a restringiria a apenas uma situação comunicativa, deixemos claro que coloquial aqui é o mesmo que informal.

De acordo com M. Seco (1973 apud Briz 2001, p. 37): 
Popular es un nivel de lengua [...] coloquial es un nível de habla [...]

Si en una lengua [...] es siempre possible señalar [...] dos estratos principales de base social, el medio (o estádar) y el popular, dentro de cada uno de ello existem modos de registros [...] determinados por la situación en que se produce el acto del hablar [...] los registros del hablar puedem agruparse en dos, formal y informal [...], caracterizados en líneas generales por la actitude convencional y por una actitude espontanea respectivamente. Hay pues, que distinguir en la lengua común grandes rasgos: nivel medio formal, nivel medio informal, nivel popular formal, nivel popular informal. El error del enfoque en que han incurridos tantos escritores ha sido identificar sin más lengua coloquial con lengua popular informal, olvidando que también hay una vertiente coloquial en la lengua media.

Podemos distinguir basicamente dois tipos de registros: formal e informal, porém devemos considerar que nos dois tipos de registros existem variações entre níveis médio e popular. Ambos podem estar presentes tanto na fala quanto na escrita. No caso específico do nosso corpus, o registro empregado é o informal, utilizado como um dos recursos que contribuem para a reconstrução da oralidade.

Briz (1998, p. 29-30) caracteriza o registro informal da seguinte maneira:

a) É um registro, nível de fala, um uso determinado pela situação, pelas circunstâncias da comunicação.

b) Não é domínio de uma classe social, pois como aqui o entendemos, caracteriza as realizações de todos os falantes de uma língua. É certo que é o único registro que dominam os falantes de nível sociocultural baixo, meio-baixo, mas de forma alguma é exclusivo dessas classes.

c) Não é uniforme, nem homogêneo, já que varia segundo as características dialetais e socioletais dos usuários.

d) Reflete um sistema de expressão que, mais que simplificação do registro formal ou do uso escrito, parece ser a continuação e o desenvolvimento do modo pragmático da comunicação humana.

e) Aparece em vários gêneros discursivos, embora seja na conversação como uso mais autêntico da linguagem, em que também mais autenticamente se manifesta esta modalidade lingüística, e, portanto, o lugar mais adequado para começar seu estudo.

f) Além de ser oral, pode manifestar-se no texto escrito.

Se caracterizarmos o registro coloquial em seu contexto de uso, será:

CAMPO: $\quad$ cotidianidade

MODO: oral espontâneo

TEOR: interativo 
TOM: informal

Vejamos agora o quadro apresentado por Briz (2001, p. 41)

\begin{tabular}{|l|l|}
\hline \multicolumn{1}{|c|}{ TRAÇOS PRIMÁRIOS } & \multicolumn{1}{c|}{ TRAÇOS SECUNDÁRIOS } \\
\hline - Ausência de planificação & - Relação de igualdade entre os \\
- Finalidade: interpessoal (a & interlocutores (seja social ou funcional) \\
comunicação pela comunicação) & - Conhecimento mútuo, saber e experiência \\
- Tom informal & compartilhada. \\
& - Marco discursivo familiar \\
& - Temática não especializada: cotidianidade \\
\hline
\end{tabular}

Pode-se dizer que coloquial é um nível de fala e que popular é um nível de língua; assim, podemos utilizar o registro coloquial ou registro formal tanto no nível de língua médio quanto no nível de língua popular.

Seus usos se baseiam no contexto situacional. A título de ilustração, poderíamos mencionar:

a) Coloquial oral: se define a partir dos parâmetros situacionais, maior relação de proximidade, e saber compartilhado, cotidianidade, menor grau de planificação e maior finalidade interpessoal. Por exemplo, uma conversa entre amigos sobre futebol.

b) Formal oral: menor relação de proximidade, menor saber compartilhado, menor cotidianidade, maior grau de planificação, menor finalidade interpessoal e hierarquia.

É importante ressaltar que o vulgarismo considerado por Briz difere um pouco do conceito de vulgarismo comumente adotado. ${ }^{10} \mathrm{O}$ autor considera vulgarismo o uso incorreto ou à margem das normas standard, ou regionais, devido ao descuido ou desconhecimento.

O aparecimento de vulgarismos ou palavras pertencentes ao léxico mais popular ocorre em função das características dos usuários, ou seja, o nível de língua que ele possui.

Em nossa análise, no capítulo "Un cumpleaño feliz", elucidaremos tal aparecimento exemplificando, com o próprio corpus, o registro coloquial.

Podemos identificar o uso do popular formal quando um falante de nível de língua baixo (popular) tenta adequar seu discurso para um nível de língua médio por exigência da situação.

Pelo fato de esse falante tentar utilizar um nível de língua não dominado por ele, poderá cometer erros como as hipercorreções: "galfo" por "garfo", "malmita" por "marmita", "afundar um museu", por "fundar um museu", entre outras.

\footnotetext{
${ }^{10}$ Vulgarismo: "término o giro empleado por gente poco educada".
} 
Briz (op. cit., p. 25) coloca que: "Es evidente que el dominio y empleo adecuado de estas modalidades linguísticas, de estos registros, es proporcional al nivel de lengua de los usuarios: mayor nivel, mayor dominio de registros"

Desse modo, não devemos confundir os conceitos apresentados acima, principalmente não considerar coloquial como igual a vulgar ou popular.

\subsubsection{Língua, sociedade e interação social pela linguagem}

Percebemos em nosso corpus traços de oralidade/coloquialidade, porém, como se trata de um texto escrito, existe a necessidade de se manter um certo padrão da língua escrita, pois esse "padrão" facilita a compreensão do leitor, uma vez que seria quase incompreensível um texto escrito exatamente como falamos. A existência das duas modalidades em um único texto, como já mencionamos anteriormente, confirma a reciprocidade existente entre fala e escrita.

A tentativa de representação da fala na escrita literária permite que percebamos que existe proximidade entre algumas formas de escrita e algumas formas de língua falada, como se percebe em Marcuschi (2001), que defende a idéia de que a escrita não é uma representação da fala, porque na escrita nós temos algo a mais e algo a menos; nem tudo que se tem na fala se pode repor na escrita, já que são sistemas paralelos e complementares, como acrescenta o mesmo autor:

A entonação só existe na fala; mas só se pode usar tamanhos diferentes e cores de letras diferentes na escrita, e a língua escrita é mais do que uma simples tecnologia.

De acordo com o autor acreditamos que pode existir uma aproximação entre as duas. Existem modalidades da linguagem que estão mais ou menos próximas da escrita ou da fala. Vemos, por exemplo, a distância que há entre um texto escrito acadêmico e uma carta pessoal; maior ainda entre o mesmo texto acadêmico e uma "conversa" na Internet. Em concordância com Marcuschi, podemos afirmar que há não apenas uma relação de continuidade, mas até mesmo uma mescla entre fala e escrita, uma vez que uma não pode ser pensada sem a outra. Há, portanto, um campo contínuo entre oralidade e escrita.

Através da língua escrita, encontramos no nosso corpus a representação da fala. Para que ela parecesse mais natural, houve um planejamento prévio, embora saibamos que, na realidade, na língua oral o planejamento é simultâneo ao ato conversacional, ou seja, ocorre no momento da conversação. Houve, portanto, um planejamento estilístico por parte do autor, que teve a intenção de imitar a espontaneidade da língua oral.

Segundo Urbano (1998, p. 149), os planejamentos prévio/local e temático/verbal 
devem ser considerados dentro de um continuum, decorre da condição de o texto escrito ser considerado como produto acabado, isto é com tempo suficiente, durante sua produção para ser planejado e elaborado, e de o texto falado ser produzido enquanto se produz.

No caso do nosso corpus, temos um texto como um produto acabado, porém com um sentido de produção imediata que nos dá a ilusão da oralidade.

Ao fazer o planejamento estilístico verbal, o autor deve considerar fatores socioculturais, como região, sexo, idade, posição socioeconômica, grau de escolaridade, entre outros, a fim de decidir que variação lingüística utilizará.

De acordo com Preti (1974), o falante poderá utilizar o que chama "dialeto social", que pode ser culto ou popular. As variações também podem estar ligadas à situação; sofrerão influências do ambiente, do tema, do estado emocional do falante e do grau de intimidade dos mesmos. Dependendo da situação em que os falantes estejam, alterará seu nível de fala (ou registro), que pode variar entre formal e informal. Essa última variação possui um caráter de estilo, pois fica a critério do falante o registro que vai usar em uma conversação. Vale lembrar, entretanto, que a escolha do tipo de registro a ser empregado está intimamente ligada ao domínio dos registros.

Nosso intuito não é abordar de forma contundente as variações lingüísticas, mas sim identificar a oralidade produzida pelo uso dessas variações. Como nosso corpus reconstrói a oralidade/coloquialidade, tomaremos como base os estudos desenvolvidos por Briz (op. cit.), pelo fato de ele trabalhar especificamente com oralidade/coloquialidade, ao contrário de Preti, que trabalha com a oralidade/culta.

No caso de o nosso corpus, a autora recria, ainda que na ficção, uma linguagem mais próxima da língua oral/coloquial, dando permissão para que as personagens "falem", e, portanto, produzam a oralidade do texto, respeitando o contexto por ele produzido. O contexto criado por Lindo sugere um registro informal, na medida em que o narrador: a) não deixa de ser uma criança; b) domina apenas o nível de língua baixo; c) mora na periferia; d) se expressa como o seu grupo; e) relata situações cotidianas nas quais a coloquialidade é imprescindível. Na interação com o leitor, o resultado, portanto, não poderia ser diferente de uma aproximação ainda maior.

\subsection{Elementos que colaboram para a representação da oralidade no corpus}

Seguindo os conceitos elencados por Briz como marcas de oralidade, apresentaremos as marcas que julgamos mais significativas para a representação da oralidade/coloquialidade no corpus. Em seguida, analisaremos mais profundamente as que, de alguma maneira, colaboram para o efeito de sentido cômico. 


\subsubsection{Gíria}

Chama-se gíria um conjunto de expressões de tipo popular. É um fenômeno lingüístico nascido em determinados grupos, sobretudo de ladrões, malandros, vadios, enfim, a marginalidade em geral.

Era a língua secreta usada, notadamente, por grupo de malfeitores que não queriam ver desvendada a comunicação entre eles. Segundo Preti, para se conhecer a gíria é preciso penetrar no mundo da marginalidade, em grupos de excluídos, que a usam como forma de se protegerem e serem identificados como membros de determinado grupo.

Entretanto, aos poucos, muitas gírias foram deixando esse caráter secreto e marginal, incorporam-se à linguagem corrente e hoje se tornaram gírias comuns, habitualmente empregadas nas mais diversas situações informais e, praticamente, em todos os níveis socioculturais, deixando assim de perecerem a um grupo restrito para fazerem parte do cotidiano de quase todos os falantes.

Sobre esse aspecto, Preti (1984, p. 24) faz o seguinte comentário:

Podemos dizer que existem duas direções nessa interação entre gíria marginal e gíria comum: de um lado, um grande número de termos da vida normal que adentra o ambiente carcerário; de outro, um considerável número de vocábulos e expressões da vida marginal que se introduz na linguagem corrente. Por esses dois fluxos pode-se concluir que há de fato, pelo menos na sociedade urbana, uma tendência considerável para o nivelamento lingüístico, da qual o fenômeno gírio é um índice expressivo.

Embora apresentem um histórico de preconceito social, ao poucos as gírias vêm sendo cada vez mais empregada, tanto na fala quanto na escrita. Sabemos também que na maioria das vezes que um autor se utiliza desse recurso na escrita, ele tem a intenção de criar algum efeito de sentido; já na fala, ela pode ocorrer mais espontaneamente. No que concerne à relação entre gíria e escrita, Preti (2000, p. 241) ainda diz que:

A gíria constitui um vocabulário tipicamente oral. Sua presença na escrita reflete apenas um recurso lingüístico, com objetivos determinados, como, por exemplo, indicar a fidelidade de uma transcrição; criar uma interação mais eficiente do 
escritor com o seu leitor, como ocorre em algumas matérias jornalísticas; dar uma realidade maior ao diálogo literal ou teatral [...]

Do ponto de vista semântico, é interessante observar que as gírias variam muito, pois o que as caracteriza é a sua extensa expressividade e criatividade, pois geralmente são criadas a partir de palavras existentes que assumem nova significação, sobretudo por meio de metáforas e metonímias, por isso a característica principal da expressão gíria é subverter a linguagem comum, ou seja, usar o léxico comum com outro significado.

No texto literário, percebemos que o uso da gíria tem o poder de marcar lingüisticamente um grupo social. É o que se nota em nosso corpus, pois a representação da espontaneidade, a dinâmica e a naturalidade da na fala é marcada principalmente pelo emprego da gíria, que exerce a função de representar um grupo de baixo-nível sociocultural que se expressa através do registro coloquial, o qual, como sabemos, está repleto de expressões gírias.

Talvez a gíria juntamente com as expressões idiomáticas sejam os elementos que mais revelam a coloquialidade e a oralidade no texto escrito literário, pois ambas são quase exclusivas da fala coloquial.

\subsubsection{Expressões Fixas}

As expressões fixas formam grupos de palavras em que se podem incluir os clichês, as frases feitas e os provérbios, que são fenômenos lingüísticos populares empregados com maior freqüência na fala.

Rodrigues Lapa (1975) denomina essas expressões fixas como "grupos fraseológicos", ou seja, grupos cujos vocábulos só adquirem significado real quando estão ligados a outros vocábulos dentro do mesmo contexto, apresentando um significado conotativo. Complementa ainda o próprio autor: "Chamamos portanto grupos fraseológicos, idiotismos, ${ }^{11}$ frases feitas ou locuções estereotipadas a esses conjuntos de palavras, em que os elementos andam mais ou menos intimamente ligados, para exprimirem determinada idéia." (op. cit., p. 62).

Há entre as expressões fixas as que podemos nomear de clichê, ou chavão, que são expressões empregadas excessivamente e que, na definição de Mattoso Câmara Jr. (2000, p. 71), é "a palavra, ou construção, a que se recorre para maior expressividade, mas que já não tem esse efeito, em virtude do seu abuso."

Talvez a presença de expressões fixas na língua falada coloquial ocorra principalmente por conta da dinâmica dessa modalidade, pois tais expressões, embora não apresentem seu sentido literal, são facilmente decodificadas e, por isso, não necessitam ser explicadas, pois favorecem a co-elaboração dos sentidos e a imediatez é garantida.

\footnotetext{
${ }^{11}$ Idiotismo é toda construção que aparece como típica de uma língua, não havendo nenhum correspondente sintático em outra língua. In: Dicionário de Lingüística Jean Dubois.
} 
Assim, vemos que as expressões fixas dentro de um texto escrito literário que reconstrói a oralidade/coloquialidade é um elemento enriquecedor, na medida em que tão bem representa a modalidade falada sob um registro coloquial.

\subsubsection{Diminutivo/Aumentativo}

As formas de diminutivo e aumentativo, no dialeto popular e na linguagem literária, podem ser empregadas como recursos lingüísticos que enfatizam usos diferentes da noção de tamanho; quando associadas semanticamente a outras palavras, podem expressar sentimentos de valores positivos ou negativos.

Assim, se as formas diminutivas podem traduzir carinho ou desprezo, o mesmo pode ocorrer com o uso do aumentativo, que pode expressar tanto valor positivo quanto negativo.

Entretanto, se geralmente o aumentativo apresenta valor pejorativo, pois o tamanho excessivo pode ser visto como feio, disforme, o diminutivo, por sua vez, geralmente apresenta valor positivo, pois a pequenez denota idéia de fragilidade, ternura. No entanto essas formas apresentarão valores positivos ou negativos de acordo com o contexto ou de acordo com a palavra a que essas formas estiverem associadas.

No corpus analisado, podemos perceber que os valores aqui empregados estão mais relacionados a questões afetivas - ora como intensificadoras ora como atenuantes - do que necessariamente à noção de tamanho, dimensional.

No que diz respeito à língua espanhola, podemos afirmar que os diminutivos, assim como os aumentativos, são muito mais freqüentes na língua falada que na língua escrita, uma vez que seu uso denota maior intimidade entre os interlocutores, pois no registro coloquial vemos, inclusive, que o diminutivo é aplicado a verbos, como corriendito, a advérbios, como ahorita, e não somente a substantivos, como estabelece a norma padrão. $O$ uso desses recursos garante maior expressividade ao texto.

\subsubsection{Repetição}

A repetição, como observa Marcuschi (1989), é a produção de segmentos idênticos ou semelhantes apresentados duas ou mais vezes no mesmo âmbito comunicativo. A primeira vez que o segmento surge, torna-se modelo para outros segmentos formulados à sua semelhança.

Os níveis de repetição podem ser fonológicos, morfológicos, sintáticos, lexicais, semânticos ou pragmáticos.

As repetições ligeiramente modificadas marcam um recurso empregado pelo falante para não repetir completamente o segmento, o que causaria empobrecimento deste.

\subsubsection{Reguladores Conversacionais/ Marcadores Interacionais}


Os marcadores conversacionais, para Castilho (1987), são sintaticamente independentes do verbo, pois podem apresentar-se no início, meio ou fim dos segmentos, exercendo a função de monitoramento da fala, regulando o que será dito, ou chamando atenção do interlocutor. Por isso, podemos afirmar que, se do ponto de vista sintático são desnecessários, para a interação discursiva, porém, são imprescindíveis.

Para Marcuschi (1989, p. 282),

marcadores conversacionais são expressões mais ou menos fixas, características da fala, elementos que operam simultaneamente, como organizadores interativos, articuladores do texto e indicadores pontuais da fala.

Seu uso freqüente proporciona a coesão e a segmentação, ainda que na fala, podem ser lexicalizados ou não, como por exemplo: "hum", "ham, ham".

Analisá-los significa admitir que a conversação é um evento interacional e cooperativo, no qual os interlocutores negociam entre si. É importante ressaltar ainda que o marcador conversacional não deixa de ser um elemento da pragmática, e que, por esse mesmo motivo, conseqüentemente, apresenta-se anterior à sintaxe, daí estar presente nas falas de crianças que ainda não dominam a sintaxe, mas que têm seus objetivos definidos ao formularem seu discurso.

Entendemos que os marcadores conversacionais devem ser analisados a partir da função interacional que exercem dentro do enunciado, pois um mesmo marcador pode apresentar diferentes funções em diferentes enunciados.

Por serem conversacionais, os marcadores remetem o texto escrito a um possível texto oral prévio ou simultâneo. 


\subsection{Comicidade/ Humor}

"se ninguém me perguntar eu sei, se o quiser explicar a quem me fez a pergunta, já não sei”

Santo Agostinho

Nessa parte do nosso trabalho, falaremos um pouco de como surgiu a "necessidade" de abordar o tema comicidade. Dizemos "necessidade", porque em princípio nosso intuito não era fazer uma abordagem dos efeitos de sentidos cômicos, mas apenas apontar e analisar as marcas de oralidade/coloquialidade presentes no corpus.

Através de uma leitura mais atenta pudemos perceber que era praticamente impossível trabalhar o corpus sem ao menos tocar na questão da comicidade, visto que a mesma é inerente a ele, pois quando o lemos rimos o tempo todo.

O riso que a leitura proporcionava, em princípio, nos causava um grande prazer, porém, aos poucos, ele foi inquietando-nos e configurando um tipo particular de humor. Decidimos, então, buscar além dos efeitos de comicidade, propriamente ditos, produzidos no texto, os mecanismos responsáveis pela sua produção.

Empiricamente, sabíamos que ríamos por conta da forma como o narrador nos apresentava as situações e que tal apresentação estava diretamente ligada à linguagem, na qual já havíamos identificado traços de oralidade e coloquialidade. Diante dessa situação, nos propusemos a identificar a comicidade presente no corpus e verificar em que medida a oralidade/coloquialidade colabora para os efeitos de sentido cômicos.

Enfim, tentaremos identificar, ainda que sem a pretensão de fazer uma análise exaustiva, se, de fato, a comicidade está diretamente relacionada à linguagem empregada no corpus.

Gostaríamos de deixar claro também que não temos a intenção de colocar em um "molde" cada um dos elementos que estão diretamente ligados à comicidade, como o humor, o chiste, a sátira, o grotesco e a ironia, pois acreditamos que eles se mesclam; por isso, defini-los com exatidão é praticamente impossível. Sendo assim, trabalharemos com tudo o que consideramos risível e, vez por outra, poderemos empregar os termos comicidade e humor ${ }^{12}$ como sinônimos.

Para abordar a questão da comicidade, nos baseamos principalmente na teoria de Bergson (2001) sobre o riso, que, a nosso ver, é a que melhor abarca, do ponto de vista da linguagem, o tema, por isso é sempre retomada por aqueles que estudam o assunto.

\footnotetext{
${ }^{12}$ Embora saibamos que humor e comicidade não são a mesma coisa, tomamos a liberdade de aproximar esses termos, pois aqui serão vistos sob a perspectiva de algo risível, portanto não nos apegaremos às questões específicas, como suas diferenças/semelhanças, principalmente por sabermos que a delimitação de um ou outro não é tão clara.
} 
Tentaremos, então, identificar os mecanismos do riso, partindo de Bergson (op. cit.), que parte da premissa de que tudo que é risível está de alguma forma relacionada ao homem, já que, em hipótese alguma, poderíamos rir de uma paisagem se ela não nos remetesse de alguma forma ao ser humano.

Ainda de acordo com autor, outro elemento fundamental para que haja o riso é a mecanização de algo vivo. Diante disso, podemos considerar cômico um homem andando feito um robô, pois nesse caso ocorreu uma automatização de seu caminhar que era algo vivo e foi mecanizado.

Podemos dizer ainda que houve o enrijecimento do que era natural, e certamente esse enrijecimento nos surpreende, uma vez que esperamos ver um homem caminhar normalmente, ou seja, de acordo com o que o grupo estabeleceu como natural, assim, quando ocorre a ruptura com o estabelecido pelo grupo como natural, o riso acontece. Podemos dizer, portanto, que o riso está relacionado aos costumes e idéias de um grupo.

Dessa maneira, podemos afirmar que o riso possui uma significação social - sendo quase sempre um desvio negativo em relação ao que é natural - e que deve ser corrigido para que se restabeleça a ordem. O efeito cômico é resultado da desarmonia seja, por exemplo, ou da vida social ou do comportamento ou até mesmo do físico.

O riso é decorrência principalmente de algo que provoca no homem uma atitude, uma frase, uma forma, um gesto que representam um elemento mecânico que acaba se sobrepondo a um elemento natural.

A teoria de Bergson (op. cit.) divide a comicidade da seguinte maneira:

- Forma

- Gestos

- Situação

- Palavras

- Caráter

A comicidade das situações e das palavras pode ter como "disparador" do riso os mecanismos de repetição, inversão, interferência e transposição.

a) Repetição - Devemos considerar que a repetição de uma palavra, de per si, não é risível; logo, não podemos isolá-la daquilo que ela nos sugere, pois ela simboliza elementos morais transpostos em materiais, caracterizando-se, conseqüentemente, como um elemento mecânico sobreposto ao vivo (p.53). Percebemos que em nosso corpus, a repetição colaborou para a comicidade, ainda que não tenha sido a causa principal.

b) Inversão - Consiste basicamente na troca de papéis, ou seja, é tudo aquilo que podemos classificar como "mundo às avessas" (p.70). 
c) Interferência - A comicidade por interferência se dá quando temos um acontecimento, pertencente a duas séries independentes, o qual pode ser interpretado a partir de dois sentidos diferentes simultaneamente, gerando um mal-entendido (p.71).

d) Transposição - A transposição tem meios tão variados que a tornam rica em formas e tons. Podemos dizer que a comicidade da transposição consiste, grosso modo, em transpor uma situação solene para uma trivial, ou seja, é usar um molde "consagrado" e recheá-lo com algo corriqueiro; entretanto, sabemos que existem transposições em graus não tão opostos como esses (p.92).

Percebemos em nosso corpus que a comicidade é fruto de todos esses elementos, os quais quase sempre se apresentam juntos em uma única "cena".

Se percebemos que a causa comum do riso é o desvio da vida na direção da mecânica, só podemos concluir que é o mecânico calcado no vivo. O automatismo e a mecanização do corpo humano nos parecem cômicos, porque fazem surgir o contraponto entre o mecânico e a vida. Um mecanismo que funciona automaticamente já não é mais vida, mas o automatismo instalado na vida passa a ser a imitação dela, o que gera, inclusive, comicidade.

Bergson afirma que cômico é todo incidente que chame nossa atenção para o físico de uma pessoa estando em causa o moral. Rimos quando as necessidades do corpo se sobrepõem à alma, ao espírito; ou rimos quando consideramos algo ridículo, absurdo ou disforme. Não nos referimos tão somente a uma deformidade física, mas de uma deformidade moral, é como se fosse uma espécie de mal hábito, de algo congelado. $\mathrm{O}$ andar natural transformado em robótico revela um mal hábito, uma deformidade que se torna ridícula, que se torna cômica. Assim, vemos que se trata de um efeito bola-de-neve, em que uma coisa leva a outra e todas levam ao riso, uma vez que todas elas se mesclam para indicar uma fuga ao considerado padrão.

De acordo com Almeida (1999, p. 42), todo indivíduo possui um comportamento padrão relativo às atitudes em geral. $\mathrm{O}$ efeito cômico surgirá de um desvio de comportamento. $\mathrm{O}$ que gera a comicidade é, mais uma vez, o enrijecimento do indivíduo, a ruptura com o esperado.

Além desse desvio de comportamento, é necessário que haja um distanciamento por parte do observador em relação ao indivíduo cômico, para que ocorra o riso, que exercerá a função de corrigir ou punir o que foi desviado. Assim, quanto mais natural nos parecer a causa do riso, como por exemplo a distração, maior será o efeito cômico produzido por essa situação, pois o indivíduo não se vê como um transgressor da norma, somente os outros o vêem. Bergson (op. cit.) corrobora essa idéia afirmando que "o sujeito cômico é invisível para si e visível para os outros".

Sabemos que para o humor aparecer é necessário que o interlocutor perceba sua superioridade em relação ao personagem que desperta riso, no entanto a dosagem deve ser 
precisa, há que se ter uma cumplicidade entre os interlocutores para que se identifiquem os absurdos como elementos cômicos. Por essa razão é que o humor é compreendido pelos mesmos grupos sociais, que são capazes de captar signos às vezes imperceptíveis por membros de outros grupos. Em outros termos, há que se identificar com o sistema de valores defendido pelo autor do discurso humorístico para que haja o riso. Por outro lado, não podemos nos emocionar com a situação, pois o riso é inteligência pura e a comoção desperta piedade. "Não há maior inimigo do riso que a emoção" (Bergson, op.cit., p.3).

De acordo com Propp (1992 p.171),

A primeira condição para a comicidade e logo para o riso que ela suscita consistirá no fato de quem ri ter algumas concepções do que seria justo, moral, correto ou, antes, um certo instinto completamente inconsciente daquilo que, do ponto de vista das exigências morais ou mesmo simplesmente de uma natureza humana sadia, é considerado justo e conveniente.

Também colaboram para a comicidade alguns elementos, como a metáfora, algumas palavras com duplo sentido, pequenas alterações em palavras ou versos, palavras tomadas ao pé da letra, jogos sonoros, paralelismo em sua construção, desconstrução de valores préestabelecidos, carnavalização, repetição de recursos que garantam o tom engraçado da narrativa, neologismo, tentativa de condensação da língua, invenção, mecanização dos movimentos, inépcias, distração, imitação, ruptura de determinismo. ${ }^{13}$

É notório que se ri menos das palavras que das coisas. Elas, porém, podem se tornar engraçadas quando quebram a expectativa do outro, quando sugere significado diferente. A forma como elas estão dispostas pode torná-las cômicas devido ao mecanismo de humor empregado.

Consideramos impossível, nesse sentido, falar em comicidade sem pensarmos em dialogismo, polifonia, pois a alusão ao objeto risível não deixa de ser uma forma de dialogismo, por isso o riso também representa uma questão social, visto que também é uma forma de discurso. Ademais, já que, segundo Baktin (1999), é impossível conceber o indivíduo fora da sociedade, o discurso é sempre social, pois está relacionado à fala de outros.

Para que se compreenda o riso, é imprescindível que se entenda a alusão contida no objeto risível, principalmente no cômico de palavras e que, além dessa compreensão, é necessária a provação de quem o compreendeu. É fundamental, pois, que haja entre os interlocutores partilha de saberes, convergências, consenso, proximidade.

\footnotetext{
${ }^{13}$ Ruptura de determinismo consiste na intervenção inesperada de um acontecimento, idéia ou raciocínio que abalam nosso comportamento diante do texto.
} 
Para que ocorra a percepção do humor presente no texto, é necessário compreender que o funcionamento da língua exige fatores de ordem não apenas gramatical, cultural ou ideológica, mas todos eles inter-relacionados. Tais dados pressupõem interlocutores que dominem um conjunto complexo de regularidades gramaticais, conversacionais e textuais para que os efeitos desejados sejam captados.

Seria interessantíssimo poder abordar todos os elementos lingüísticos e culturais citados acima, o que certamente tornaria tal análise próxima do ideal, mas tivemos de fazer, em função dos propósitos desta pesquisa, um recorte e nos delimitar em aspectos da oralidade/coloquialidade e sua respectiva colaboração para a produção de efeitos cômicos.

O uso de recursos desencadeadores do riso não serve apenas para recriar situações inusitadas e absurdas que divertem o leitor, mas também serve para fazê-lo refletir sobre a realidade. Segundo Travaglia (1990, p. 59),

[...] o humor desempenha na sociedade um papel social e político através de certas funções, uma das quais é básica: o ataque ao estabelecido, à censura, fazendo do humor um lugar a se escapar à cultura (o que é social, mas também antropológico) de mostrar outros possíveis padrões escondidos.

Para Baktin (1996), o cômico é usado como instrumento de transgressão não só contra determinados valores ideológicos, mas também na luta contra a lógica da linguagem na qual aqueles mesmos valores se organizam e continuam se organizando.

Segundo Ziraldo Alves Pinto, "o humor é arte. A arte de descobrir a verdade, utilizando o homem a sua capacidade de inventar" (Vozes, 3. vol., LXIV, abril/1977, p. 194). O compromisso do riso está na descoberta inesperada da verdade "não que esta seja engraçada, mas sim a forma que se chega até ela".

Embora o texto humorístico possa parecer, para muitos, banal, há nele contido um árduo trabalho, por parte do enunciador, de observação e análise de si e dos outros e do mundo. O riso, inclusive o provocado por ele, propõe uma nova ordem do cotidiano e nos permite um olhar diferente daquele que nos impõe os valores dominantes.

Em "Un cumpleaños feliz", podemos identificar alguns dos mecanismos para a produção da comicidade, tais como a quebra de expectativa, o jogo sonoro, o paralelismo e a automação de algo natural. Neles podemos perceber ainda, de acordo com Bergson, a transposição, a inversão, a repetição, a automatização sobre aspectos naturais do cotidiano.

Em nosso corpus, a distração natural por parte de Manolito, muitas vezes, rompe com o que se espera, ou seja, rompe com os padrões, produzindo um efeito cômico. A ingenuidade do garoto revela o seu mundo de forma cômica, ainda que crítica, conforme veremos em seguida. 
Como se viu, é possível criticar de forma lúdica. O risco, entretanto, é que isso causa conflito e desestrutura padrões aceitos, que logo são reestruturados ao serem vistos sob a ótica do absurdo, processo esse que produz também o riso. 


\section{CAPÍTULO 3}

\section{Tabela e Análises}

Apresentaremos neste capítulo a tabela que apresenta os elementos que consideramos mais significativos na representação da oralidade. A ordem da disposição dos elementos foi aleatória.

A tabela possui três colunas, sendo que a primeira indica o tipo de marca de oralidade, a segunda indica o número da linha em que a marca se encontra e a terceira apresenta 0 fragmento que contém a marca de oralidade.

Conforme salientado já inúmeras vezes, analisaremos de forma mais contundente as marcas que, de alguma maneira, estão relacionados aos efeitos de comicidade. 
3.1 TABELA - MARCAS DE ORALIDADE

\begin{tabular}{|c|c|c|}
\hline $\begin{array}{c}\text { Tipo de } \\
\text { ocorrência }\end{array}$ & Linha & Fragmento \\
\hline Aumentativo & $\begin{array}{l}213 \\
253\end{array}$ & $\begin{array}{l}\text { Después del portazo de mi abuelo pensé que mi madre se iba } \\
\text { enfadar... } \\
\text { Nos llevamos un cortazo y un tortazo. } \\
\text { Que fue un exitazo }\end{array}$ \\
\hline Diminutivo & $\begin{array}{l}97 \\
204 \\
214\end{array}$ & $\begin{array}{l}\text { El que la que tiene se la hicieron un pelín grande } \\
\text { No se podía tocar ni un panchito porque estaban contados } \\
\text { Mi madre dijo que al que volviera a abalanzar sobre la comida le } \\
\text { daba un bocadillo para que se lo comiera solo y triste en el parque } \\
\text { de Ahorcado }\end{array}$ \\
\hline $\begin{array}{c}\text { Marcadores } \\
\text { Conversacionais }\end{array}$ & $\begin{array}{c}86 \\
129 \\
156 \\
158 \\
174\end{array}$ & $\begin{array}{l}\text { Pero, ochenta años no se cumple todos los días. } \\
\text { Además, ¿qué amigos tengo yo? } \\
\text { Y encima, como eres viejo, la gente sólo te regala bufandas } \\
\text { Pues dinos lo que quieres que te regalemos } \\
\text { Pues nada, sin amigo viejo } \\
\text { Y como me entere de que vuelves a tirar polvorones por la terraza, } \\
\text { vás tú detrás. } \\
\text { Bueno, había salido sano y salvo, sin cicatrices, no me podía } \\
\text { quejar. } \\
\text { "Pues bueno", y cerraba los ojos para dormirse } \\
\text { "Pues bueno, pues vamos" } \\
\text { La verdad es que daba el pego, } \\
\text { Bueno, al fin y al cabo } \\
\text { entonces el simpático doctor Morales, ese doctor de serie de } \\
\text { televisión, nos dijo que se no teníamos nada que hacer en nuestra } \\
\text { casa. } \\
\text { - ¿Y todos estos? } \\
\text { pues he pensado que voy a probar dos o tres años del siglo XXI. }\end{array}$ \\
\hline
\end{tabular}




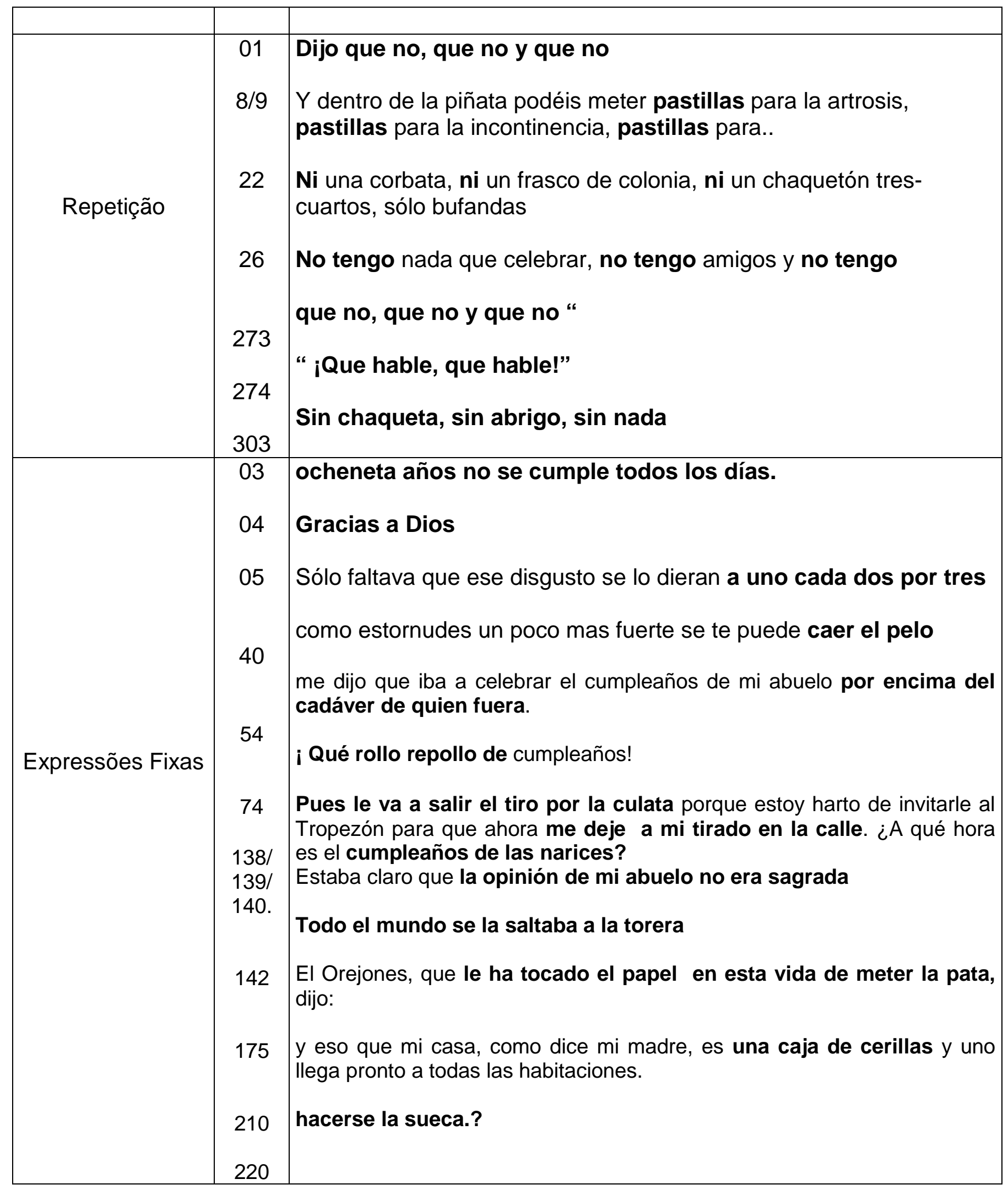




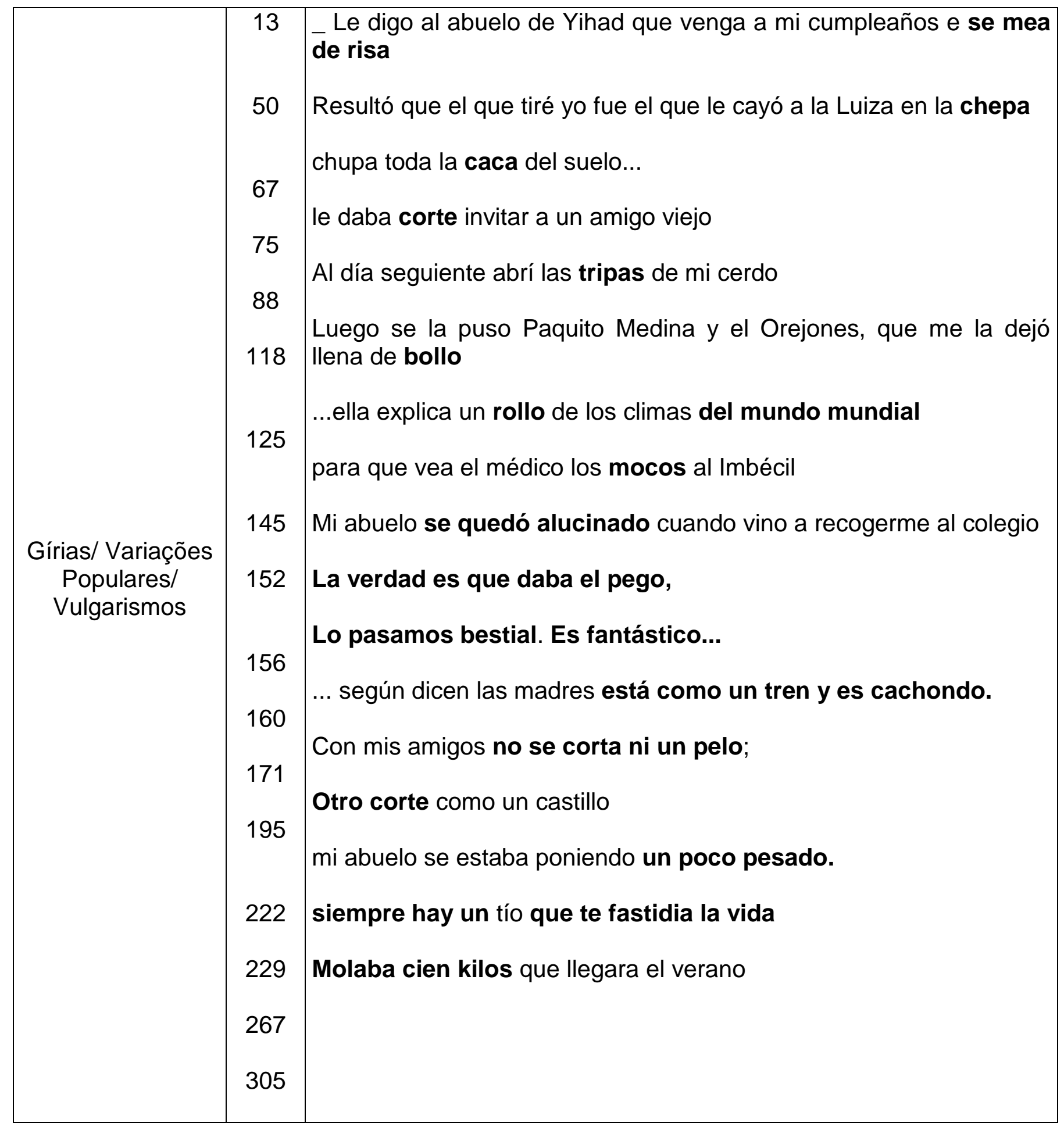

\subsection{Análise I - Marcas de oralidade}

Pelo fato de o corpus apresentar vários tipos de marcas de oralidade, acreditamos que seja necessário manter a mesma ordem dessas marcas dispostas na tabela, a fim de facilitar 0 acompanhamento da análise.

Vale lembrar que tomaremos para uma análise mais profunda aquelas marcas que julgamos estarem diretamente relacionadas à produção da comicidade, ou seja, marcas de 
oralidade presentes nos trechos cômicos selecionados para análise, ao passo que, quanto às marcas que não estão diretamente relacionadas à comicidade, faremos uma análise mais sucinta.

\subsubsection{Aumentativo/Diminutivo}

Como já falamos anteriormente, em geral, os sufixos que formam o aumentativo tendem a ser pejorativos, pois remetem à idéia de brutalidade, disformidade, porém, dependendo do contexto, tais sufixos também podem assumir um tom valorativo. Em ambos os casos, o contexto é imprescindível para que determinemos o valor empregado.

Quanto aos sufixos que formam o diminutivo, via de regra, a primeira idéia que se tem deles é a de que tendem a expressar certa amabilidade ou infantilidade, idéia contrária à de que normalmente se tem dos sufixos associados ao grau aumentativo, que expressam disformidade, exagero.

Por outro lado, dependendo do contexto, podemos usar o diminutivo quando queremos nos referir à falta de algum atributo, o que o tornará pejorativo; assim como, em determinados contextos, podemos usar o aumentativo para valorar algo. Desse modo vemos que tanto o diminutivo quanto o aumentativo podem ser atenuante ou intensificador.

Encontramos apenas três ocorrências de aumentativos, todas apresentando-se como intensificadores, sendo que os dois primeiros intensificam negativamente, ao passo que o terceiro intensifica de forma positiva.

Vejamos como essas marcas são expressas no texto:

Linha 37 Después del portazo de mi abuelo pensé que mi madre se iba enfadar...

\section{Linha 213 Nos llevamos un cortazo y un tortazo}

Nas frases acima, as palavras em negrito, empregadas no aumentativo, receberam tom pejorativo, pois a própria atitude do avô, ao bater a porta com força, é uma atitude negativa. $\mathrm{O}$ aumentativo, nesse caso, evidencia a negatividade do gesto que está relacionado ao mau humor do avô.

O emprego dessas palavras - tortazo e cortazo, que em português seria "cascudo", ou seja, um murro leve - se justifica pelo fato de que Manolito se faz de vítima, uma vez que, ao saber que contrariara sua mãe, intensifica o corretivo aplicado por ela, ao dizer que não havia recebido um simples tapa, mas um tapão. Subentende-se, então, que a "dor" de um tapão é maior, o que confirma que a punição foi aplicada, assim o garoto e sua mãe estão quites. 
Como a agressão física também é uma coisa negativa, a dimensão dela, por meio do emprego do aumentativo, torna-a ainda mais depreciativa.

Nas frases abaixo temos o uso do diminutivo, que, diferentemente do aumentativo empregado acima, recebe um valor positivo, ou simplesmente marca uma forma coloquial de se expressar.

\section{Linha 97 ¿El que la que tiene se la hicieron un pelín grande}

Pelín significa "pouquinho", é uma forma de diminutivo tipicamente oral, em vez de se dizer poquito (mais comum), opta por uma palavra que denota maior informalidade, portanto maior proximidade entre os interlocutores.

O tom manifestado aqui parece ser carinhoso, pois, apesar de afirmar que a dentadura de seu avô fora feita um pouco maior, apresentando, assim, um "defeito", ele o minimiza, pois se trata uma pessoa muita querida, seu avô Nicolas. Não há dúvidas de que, nesse caso, a função do diminutivo é a de atenuante. Com relação ao efeito cômico, o objeto em si dentadura -, que já tem uma conotação repulsiva, contribui para a produção do efeito de ridículo, principalmente se a imaginarmos se movendo folgada na boca de um idoso, como é o caso do avô de Manolito, por causa de tamanho errado. O poder imagético é altamente sugestivo nessa passagem.

Linha 204 ¿No se podía tocar ni un panchito porque estaban contados

O termo panchito também remete a situações bastante coloquiais. Como a situação apresentada no texto é familiar, ao optar por panchito, uma palavra da língua espanhola, no

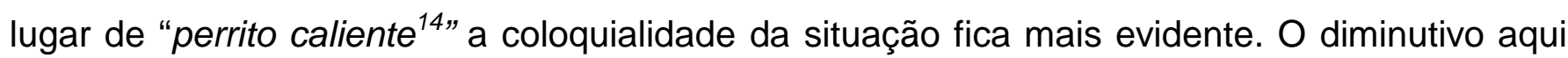
empregado tem a função de minimizar o fato de Manolito querer comer antes de todos. Minimizando a situação através do diminutivo, é como se ninguém percebesse sua atitude, afinal era apenas um "sanduichinho".

Ao não dar importância ao "sanduíchinho", também não se daria importância ao fato de novamente estar desobedecendo a sua mãe, por isso a atenuação sugerida pelo uso do diminutivo é em relação ao ato de desobedecer.

O efeito cômico aqui fica por conta de um fato que de per si não é cômico, a pouca comida; entretanto, em função de os sanduíches estarem contados, um passa a controlar o que os outros comem, e tal controle é hilário.

\footnotetext{
${ }^{14}$ Tradução do inglês hot dog.
} 
Linha 214 ¿Mi madre dijo que al que volviera a abalanzar sobre la comida de daba un bocadillo para que se lo comiera solo y triste en el parque de Ahorcado

Diferentemente do uso feito na frase acima, o diminutivo aqui não tem o valor de atenuante, e sim expressa maior coloquialidade, pois é comum que se diga bocadillo por bocata.

Desse modo, vemos que essas formas a) dão expressividade ao texto; b) enfatizam alguns usos que não necessariamente os que se referem a tamanho; c) apresentam várias nuances, atenuando, intensificando ou simplesmente inserindo uma forma coloquial de se expressar.

\subsubsection{Reguladores conversacionais / marcadores interacionais}

Os marcadores conversacionais, que podem ser chamados de marcadores interacionais ou, em espanhol, de reguladores conversacionais, colaboram como organizadores da interação e articuladores do texto.

É importante lembrar que os marcadores seguem regras de comunicação e não necessariamente sintáticas, por isso, muitas vezes, um determinado vocábulo perde seu sentido primeiro e funciona somente como um marcador da interação.

Eles podem ser verbais - quando se caracterizam como elementos de ligação entre as unidades comunicativas (partículas, palavras, sintagmas, expressões e orações de diversos tipos) - ou não-verbais, ou seja, de natureza puramente supra-segmental, mais comuns na fala face-a-face; na escrita, para tentar representá-los, é preciso usar recursos expressivos, como a pontuação e/ou o uso diferenciado dos grafemas.

Por se tratar de uma marca inerente à fala, esses marcadores são elementos cujo número de ocorrências é muito representativo, embora valha ressaltar que os marcadores, conforme já mencionado, não contribuem de forma direta para a produção da comicidade.

Operando como organizadores da "suposta" conversa entre os personagens, temos os seguintes marcadores:

Linha 03 - Pero, ochenta años no se cumple todos los días.

Ao iniciar a frase, a mãe de Manolito usa o termo pero para contrapor a idéia de seu pai, Nicolás, que não querer comemorar seus 80 anos. Há, portanto uma oposição de idéias em relação ao aniversário e adversidade é caracterizada pelo marcador.

Linha 11 - Además, ¿ qué amigos tengo yo? 
Para reafirmar a posição de não querer a comemoração de seu aniversário, o marcador además funciona como um argumento usado logo no início da frase; acrescentando a pergunta sobre seus amigos, esta sugere que ele não os tem.

Linha 21 - Y encima, como eres viejo, la gente sólo te regala bufandas

A conjunção aditiva é chamada, em espanhol, de copulativa. É típica nos inícios dos turnos e, muitas vezes, dá prosseguimento ao que vinha sendo dito. Na frase acima, a adição de um protesto é introduzida pelo $Y$, reforçada pelo termo encima ("ainda por cima"). A função dessa expressão é intensificar a frase e proporcionar um efeito cumulativo.

Linha 24 - Pues dinos lo que quieres que te regalemos

O emprego do pues não assume aqui a função de conjunção, mas sim de um marcador argumentativo, usado pela mãe com o intuito de dar um basta nas lamentações do avô, pois, de certa forma, além de intimá-lo a falar o quer ganhar de presente, ainda o faz parar de se lamentar.

Linha 76 - Pues nada, sin amigo viejo.

O pues nada, dito por Manolito, tem a função de concordar, já que aceita a opinião do avô, ainda que contrariado, pois não parece estar convencido. O nada, palavra que denota vazio, reforça que realmente não haverá velhos.

Linha $78-Y$ como me entere de que vuelves a tirar polvorones por la terraza, vas tú detrás.

O marcador tem a função de adicionar uma advertência, é uma estrutura condicional que traz um efeito de ameaça (si me entero de ...) por parte da mãe ao garoto, após ter combinado com ele como fariam a festa surpresa. Esse marcador rompe com o assunto que estava sendo desenvolvido, chamando atenção para a advertência.

Linha 80 - Bueno, había salido sano y salvo, sin cicatrices, no me podía quejar. 
Nessa frase, ao empregar o marcador, Manolito expressa uma sensação de alívio, afinal não havia sido castigado por sua mãe, apesar de sua travessura. Como se percebe, o sentido primeiro da palavra se aplica à situação que teve um bom desfecho.

Linha 86 - "Pues bueno", y cerraba los ojos para dormirse

O pues bueno, nessa frase, expressa total concordância com o que diz Manolito, pois já é tarde da noite e o avô sonolento não presta muita atenção no que diz o neto, serve também para finalizar a conversa.

\section{Linha 129 - "Pues bueno, pues vamos"}

$\mathrm{Na}$ fala dos amigos de Manolito, percebe-se um ar de desagrado, pois foram convidados para irem à festa de aniversário e não a um posto médico. $O$ aviso de que terão que ir ao médico antes da festa é como se fosse o preço do convite, sendo assim concordam com um "Pues Bueno, pues vamos", se temos que ir então vamos.

\section{linha 156 - La verdad es que daba el pego}

Para dizer que estavam enganando seu avô, Manolito introduz a frase com um marcador La verdad es que ("na realidade") que possui um a carga semântica contrária à informação que seguirá,há uma oposição entre o engano na ação e o modo de introduzí-la.

A oposição dos sentidos das palavras mostra certo cuidado na elaboração do texto.

\section{Linha 158 - Bueno, al fin y al cabo}

É um marcador típico de início de turno, que normalmente justifica um comentário feito anteriormente. A função do marcador é introduzir uma expressão finalizadora com aspecto positivo.

Linha 174 - ...entonces el simpático doctor Morales, ese doctor de serie de televisión, nos dijo que se no teníamos nada que hacer en nuestra casa.

O advérbio temporal dá progressão à narrativa na medida em que introduz e marca uma nova informação: introduz, no texto, a bronca dada pelo médico, além de marcar a simultaneidade dos fatos, ou seja, junto com a bronca do médico, a bagunça dos garotos. 
A esta altura, já está mais do que claro que os marcadores em si, efetivamente, não colaboram de fato para o efeito cômico no texto; às vezes, o que ocorre é que ele introduz uma situação cômica, reproduz, sobretudo, a tomada de "turnos" entre os interlocutores.

\section{Linha $194-i Y$ todos estos?}

A função desse marcador é adicionar uma desaprovação por parte da mãe, ao ver Manolito com seus amigos, já que não havia preparado uma festa para tanta gente.

Linha 278 - ...pues he pensado que voy a probar dos o tres años del siglo XXI.

O pues exerce a função de introdutor da conclusão a que chegou o avô após ter refletido sobre a vida, ou seja, a de viver um pouco mais.

\subsubsection{Repetição}

A repetição consiste na reprodução de um mesmo segmento discursivo, podendo ser fonológico, morfológico, sintático, lexical, semântico e pragmático. Esse recurso lingüístico é muito importante para a representação da oralidade na escrita, porque se trata de um fenômeno inerente à fala, e tem como função auxiliar na construção de um novo conteúdo e/ou retomada de um outro anteriormente citado, para dar seqüência ao segmento discursivo. A dinâmica da oralidade permite que se repita o mesmo segmento discursivo várias vezes de forma idêntica ou semelhante, sem que isso se torne cansativo, ao contrário da escrita, que, quando necessita retomar algo, tem de fazê-lo de forma mais elaborada para que o texto não empobreça, visto que a forma que está apresentado permite que se retome o segmento quantas vezes desejar.

A repetição, ligeiramente modificada, é um recurso utilizado para não se repetir completamente um segmento é como se fosse uma retomada da idéia para dar continuidade, assim como fazemos ao falarmos. Também podem funcionar como intensificadores dando maior ênfase à mensagem.

Assim como os marcadores conversacionais, as repetições nem sempre colaboram diretamente para a produção de um efeito cômico no texto, mesmo que possa haver passagens em que coincida a ocorrência da repetição com a cena humorística. O certo é que sabemos que ela não funcionou como um elemento "disparador" do riso, por isso analisar a repetição sob esse aspecto nos pareceu um tanto quanto "forçado". Apenas mencionaremos as suas ocorrências, até mesmo porque ela é uma marca de oralidade muito importante. 


\section{Linha 01 - Dijo que no, que no y que no}

Aqui temos exatamente o mesmo discurso classificado em dois tipos, Indireto e Indireto Livre. Ademais, achamos que a representação da palavra não pode ser considerada construção fiel nem como sendo considerada incorporada à fala do narrador. Trata-se de um caso em que temos a sensação da ambigüidade polifônica, uma vez que Manolito reproduz a fala do avô, que insiste em não querer comemorar seu aniversário,

Linhas 8/9 -Y dentro de la piñata podéis poner pastilla para la artrosis, pastilla para la incontinencia, pastilla para la tensión... - Si invito a unos amigos esto puede parecer un asilo. No me gusta, todo lleno de viejos, Ileno de dentaduras postizas, de juanetes, no quiero. Además ¿qué amigos yo tengo?

No primeiro caso, temos repetição lexical da palavra pastillas ("comprimidos"), que serve para enfatizar a argumentação do avô sobre o ridículo que seria fazer uma festa de aniversário aos oitenta anos. Para isso, repete que dentro dos balões em vez de haver balas e doces, haveria comprimidos medicinais para doenças senis. A mesma intenção se teve ao utilizar o adjetivo lleno ("cheio"), que nos dá a sensação de uma cena feia, pois os vocábulos aqui empregados têm uma carga semântica que nos remete a essa idéia, pois não está cheio de flores, ou algo bonito, e sim cheio de velhos, dentaduras e joanetes, o que provoca um efeito hilariante, pois banaliza os males da velhice.

Linha 22 - ...ni una corbata, ni un frasco de colonia, ni un chaquetón tres-cuartos, sólo bufandas...

O avô repete a palavra $\mathrm{Ni}$ ("Nem") para reclamar o fato de ganhar somente cachecóis, o que aos olhos dele é um presente que se dá aos velhos. Segundo o avô, nessa idade não te presenteiam com jaquetas nem com colônias nem gravata, presentes que parecem dar ao homem certa virilidade, pois são "acessórios" que o podem torná-lo mais atraente. Ele até poderia usar o tampoco para representar as diversas negativas, mas não causaria o mesmo efeito de desabafo. Fica patente o cuidado da autora ao usar tal estratégia, que tão bem representou a oralidade/ coloquialidade.

Linha 26 - ¡Nada! No tengo nada que celebrar, no tengo amigos y no tengo ganas de cumplir ochenta años; lo único que tengo son bufandas de los cumpleãnos anteriores 
Temos outra negativa que vai ao encontro do estado de espírito do avô naquele momento. Trata-se da palavra nada, que é reforçada pelo no tengo, que, por se apresentar repetidas várias vezes, reforça o intuito de dimensionar a angústia do avô, angústia por estar cumprindo oitenta anos e não ter nada. Ocorre também a repetição do assunto cachecol, reforçando a idéia de que ele possui apenas coisas próprias de velho.

Linha 273 - Mi abuelo decía que no, que no, y que no.

Aqui ocorre a mesma ambigüidade anterior, porém o tempo Pretérito imperfeito nos dá a sensação de maior distanciamento. Nessa passagem do texto, ainda que o avô intensifique sua fala repetindo que não irá discursar, a situação é bastante diferente da situação apresentada na frase anterior, pois na primeira o clima era dominado pela tensão, ao passo que na segunda o clima é de descontração e alegria. Dessa forma, vemos que a negativa apresentada pelo avô, em realidade, não é porque não queira discursar, e sim porque está com vergonha de fazê-lo.

\section{Linha 274 - "iQue hable, que hable!”}

A repetição na frase acima caracteriza o pedido de discurso como uma insistência dos convidados, que normalmente fazem essa brincadeira para que o aniversariante fique ainda mais constrangido.

\section{Linha 303 - sin chaqueta, sin abrigo, sin nada}

Temos, nesse caso, a repetição da estrutura, propiciada pela repetição da palavra sin, que reforça "o não possuir", ou não ser presenteado pelas vestimentas citadas. Com o intuito de dimensionar o "não possuir", ele conclui com a palavra nada, que resume tão bem a ausência de algo. A repetição produz um efeito de "somatória de males".

\subsubsection{Expressões Fixas}

Podemos considerar expressões fixas os clichês, as frases feitas, os provérbios e as gírias.

As palavras empregadas nessas frases só adquirem significado quando estão juntas com outras no mesmo contexto, como por exemplo: sorriso -amarelo. Se empregadas separadamente, a palavra "sorriso", que significa expressão de satisfação, alegria, e a palavra 
"amarelo", que nomeia uma cor, percebemos que em nada lembram a expressão sorriso amarelo, que significa um sorriso sem graça, forçado.

Portanto, é o contexto e a junção das palavras que produzem o efeito de sentido desejado.

Dentro das expressões fixas, temos ainda os provérbios, que, entre todas, é a forma mais fixa, pois não admite modificações e, geralmente, transmitem um ensinamento moral; porém para que sejam compreendidos devem ser comum a um grupo social.

Tais expressões facilitam a comunicação, pois, pelo fato de já estarem prontas, não há esforço para sua produção, tampouco para sua decodificação.

Devido à difícil tipificação das expressões idiomáticas, não temos a pretensão de classificá-las, pois acreditamos que muitas delas transitam entre uma e outra classe.

Pelo fato de que essas frases apresentam em si mesmas seu significado, faremos apenas uma simples explicação, baseando-nos no contexto em que elas se encontram.

Por se apresentar muito mais na fala que na escrita, percebemos o grande número de ocorrências dessa marca, pois ela revela a coloquialidade da fala. Consideramos curioso o fato de que a maioria das expressões utilizadas são ditas pelos adultos - das doze ocorrências encontradas, apenas três foram ditas por Manolito, já as demais, são expressas através de citações da fala de outros personagens adultos.

Linha 03 - ...ochenta años no se cumple todos los días.

A mãe de Manolito, com o intuito de convencer D. Nicolás, faz uso da frase acima para ressaltar a importância de comemorar o aniversário dele.

Linhas 04/05 - Gracias a Dios. Sólo faltaba que ese disgusto se lo dieran a uno cada dos por tres

As expressões acima expressam um alívio por parte do avô, que agradece a Deus pelo fato de "sofrer tal desgosto" apenas uma vez, e não a cada dos por tres, pois seria demasiado se tal fato ocorresse com freqüência.

Através do agradecimento, também podemos perceber que a religiosidade está presente na cultura espanhola, ainda que não signifique que as pessoas que façam uso de tais expressões sejam necessariamente religiosas.

Linha 74 - i Qué rollo repollo de cumpleaños! 
Temos aqui uma expressão típica das crianças, portanto uma gíria infantil, que se torna divertida pelo jogo sonoro que produz a rima. Semanticamente, representa algo chato ou difícil.

Linhas 138/139/140 - Pues le va a salir el tiro por la culata porque estoy harto de invitarle al Tropezón para que ahora me deje a mi tirado en la calle. ¿ $A$ qué hora es el cumpleaños de las narices?

Nesse caso, temos uma seqüência de "expressões" que tão bem mostram o descontentamento do avô de Yihad pelo fato de não haver sido convidado para o aniversário de seu amigo Nicolás. Ele revida dizendo que o amigo terá seu troco, ou seja, que as coisas sairão justamente contrárias ao planejado pelo avô de Manolito. Realmente cumpre com o que disse, pois, além de ir à festa sem ser convidado, ainda leva consigo mais outros amigos igualmente idosos. Além do mais, mesmo estando interessado no aniversário, faz questão de desdenhar a festa, o que fica explícito com a seguinte pergunta ¿A qué hora es el cumpleaños de las narices?

Talvez pelo fato de ser um livro infanto-juvenil, a expressão "de las narices" tenha sido empregada como forma de atuar a expressão mais comumente usada com efeito depreciativo "de merda". Embora as duas expressões contenham uma carga semântica negativa, "de las narices" pode ser considerada uma espécie de eufemismo, ao passo que "de merda" poderia parecer um tanto quanto agressivo em um contexto infantil, mesmo sabendo que é uma expressão usada com freqüência na linguagem oral informal.

No Brasil também usamos o mesmo órgão, nariz, para atenuarmos algumas expressões mais grosseiras. Temos, por exemplo, a expressão "vai tomar no nariz", como atenuadora de "vai tomar no c...", ou "fez tal coisa como o nariz" para dizer que algo foi mal feito.

Linha 142 - Estaba claro que la opinión de mi abuelo no era sagrada Todo el mundo se la saltaba a la torera

Temos aqui um modo de intensificar o fato de que todos fazem o que querem com o avô, pois sua palavra não tinha valor, ou seja, não era respeitada. Para reforçar essa afirmação, ele utiliza a expressão Todo el mundo se la saltaba a la torera, pois não eram apenas algumas pessoas, mas todo mundo, ou seja, o exagero intensifica o fato de que as pessoas não respeitam suas opiniões.

Linha 175 - El Orejones, que le ha tocado el papel en esta vida de meter la pata, dijo:

Aqui Manolito afirma que seu amigo é um expert em equivocar-se, melhor dizendo, sempre "dá um fora". 
Linha 210 y eso que mi casa, como dice mi madre, es una caja de cerillas y uno llega pronto a todas las habitaciones.

Ao dizer que sua casa é uma caja de cerilla (caixa de fósforos), ganha-se maior expressividade do que se usasse um diminutivo para explicar a pequenez da casa.

\section{Linha $220-\ldots$ hacerse la sueca}

A expressão nos remete à idéia de que a mãe primeiro observa, mas faz de conta que não está vendo, para não perder a compostura naquele momento, pois, se tratava de uma festa, e a mãe não gostaria de ter de chamar a atenção de um convidado. Entretanto, logo vemos que isso é inevitável, pois os garotos extrapolam.

\subsubsection{Gírias/ Variações populares/ Vulgarismos}

Consideramos que as gírias também fazem parte das expressões idiomáticas, não obstante, por apresentarem um caráter algumas vezes mais fugaz e pertencerem a grupos restritos, ou estarem relacionadas a faixas etárias, resolvemos analisá-las juntamente com variações populares e vulgarismos.

Gostaríamos de deixar claro que existem diferenças entre os termos gíria, vulgarismos e variantes populares, porém resolvemos agrupá-los juntos pelo fato de que muitas vezes um pode estar atrelado a outro, ou seja, um vocábulo gírio (comum) pertence a uma variação popular e às vezes também poder ser considerado um vulgarismo, visto que grande parte das gírias apresenta alguma 'deformidade' de palavras já existentes.

Não temos a preocupação de "desvendar" o significado das gírias, apenas procuraremos compreendê-las através do contexto, pois o nosso intuito é mostrar que ela foi utilizada no texto para representar a oralidade/ coloquialidade, assim nosso objetivo é mostrar que ela está presente, sem a pretensão de fazer grandes análises.

Linha 13 - Le digo al abuelo de Yihad que venga a mi cumpleaños e se mea de risa.

Com o verbo mear (mijar) "él se mea de risa", temos aqui uma variante popular, que indica intensidade, como se percebe no exagero que é dizer que alguém "se mija de rir". O uso dessa variante popular coloquial provocou um efeito de sentido, pois não causaria o mesmo efeito dizer "él se orina de tanto reir". A graciosidade da cena seria tolhida pelo discurso. 


\section{Linha 50 - el que le cayó a la Luiza en la chepa}

O uso da variante popular e chepa ("corcunda"), em vez de joroba, indica familiaridade, e, como a Luisa, segundo Manolito, é quase da família, o uso de chepa evidencia a proximidade existente entre os vizinhos, pois o garoto não parece ter a preocupação de usar um termo mais formal para indicar uma deformidade física da vizinha, sente-se à vontade para usar um termo familiar.

A cena é graciosa não por apresentar a deformidade física de Luisa, mas pelo fato de ela ser atingida por um biscoito "voador" justamente nessa parte do corpo.

Linha 67 - ...chupa toda la caca del suelo...

O termo caca é bastante genérico tanto em espanhol quanto em português. Na sentença em questão, ele é usado para designar a sujeira de todos os tipos que é encontrada no chão. Por ser um termo genérico, cujo significado é determinado pelo contexto, é também conhecido como termo econômico, elemento presente predominantemente na conversação e responsável pelo dinamismo dessa modalidade de comunicação. Seu uso ratifica mais uma vez o cuidado na escolha vocabular para a representação da oralidade/coloquialidade no texto.

\section{Linha 75 - ...le daba corte invitar a un amigo viejo}

A expressão gíria corte se refere a um não gostar ou não querer. percebemos então que dito isso de maneira um pouco mais formal como "meu avô não queria velhos em sua festa", não causaria o mesmo efeito de oralidade/coloquialidade que causou a expressão gíria, afinal ela é um fenômeno bastante presente na oralidade/coloquial, porém não exclusivo dessa modalidade.

Linha 88 - al día seguiente abrí las tripas de mi cerdo

O uso da variante popular tripas por barriga parece com mais precisão o ato de abrir 0 porquinho ("cofrinho"), ou seja, soa como se o porquinho tivesse sido perfurado mais profundamente, de modo que chegasse até as tripas, permitindo, assim a retirada de todas as moedas, ao passo que o uso do termo "barriga" poderia nos dar a idéia de abertura mais superficial, ou seja, não tão profunda, o que dificultaria a retirada de tais moedas. 
Linha 118 - Luego se la puso Paquito Medina y el Orejones, que me la dejó llena de bollo

A palavra bollo, que em espanhol é uma espécie de pão ou bolo, nessa sentença assume um sentido conotativo, é algo como saliva, porém com um aspecto muito mais repulsivo. O uso dessa variante popular cria esse efeito de coloquialidade e de proximidade, pois é comum o emprego pelas crianças dessa variante.

\section{Linha 125 - ...ella explica un rollo de los climas del mundo mundial}

A palavra gíria rollo resume a idéia de um assunto desinteressante, é uma forma mais objetiva de mostrar a insatisfação com relação ao conteúdo que está sendo explicado pela professora, é uma gíria usada particularmente pelos jovens. Encontramos também como marca de oralidade o jogo sonoro mundo mundial, que nos remete à idéia de algo pueril. A dimensão dada à palavra mundo é reforçada pelo adjetivo mundial, o qual nos remete a idéia de aumento, é como se apenas a palavra mundo, sem o adjetivo mundial, não desse conta de explicitar a grandiosidade física que o garoto queria destacar. Vemos que em uma mesma oração encontramos dois tipos de marcas de oralidade/coloquialidade: a gíria comum rollo dizemos comum por não pertencer apenas a um grupo e não possuir um caráter criptológico e mundo mundial, um jogo sonoro usado principalmente por crianças devido ao efeito de graciosidade que pode produzir.

Linha 145 - Para que el médico veo los mocos al Imbécil

A palavra moco é por nós considerada uma variante popular para secreção nasal, embora possua um aspecto repulsivo por se tratar de algo escatológico; é comumente empregada em situações informais, e certamente a única variante que conhece o nosso personagem.

\section{Linha 152 - Mi abuelo se quedó alucinado cuando vino a recogerme al colegio}

A palavra alucinado pode ser caracterizada como gíria, pelo fato de assumir um significado diferente daquele "que sofre de alucinação". Nesse caso, a idéia transmitida é de "susto ou surpresa" por parte do avô, que não esperava ter de levar consigo todos aqueles garotos, que certamente dariam algum trabalho. 


\section{Linha 156 - La verdad es que daba el pego}

A gíria dar pego significa que algo "falso" poderia assumir o papel de verdadeiro devido a semelhança. No texto, levando em conta que os velhos não possuíam uma visão privilegiada por conta da idade, a barata espetada em um palitinho e com uma cor parecida com a de uma azeitona preta poderia se passar por um petisco. No entanto, o fato de a barata mexer as perninhas fez com que os avôs suspeitassem e não caíssem na traquinagem dos garotos. Interessante observar que a gíria explica de uma maneira bastante sucinta, ou seja, dela fazem parte basicamente expressões "explicativas".

\section{Linha 160 - Lo pasamos bestial. Es fantástico...}

A palavra gíria bestial, diferentemente de um sentido negativo como brutal, assume aqui a idéia de algo bastante positivo, ou seja, o passeio foi extraordinário, possui o mesmo significado que a gíria "animal" em português (do Brasil), que, igualmente, assume um valor positivo. Para dimensionar esse aspecto positivo, Manolito acrescenta outro adjetivo fantástico - também empregado com o sentido conotativo, pois aqui fantástico não está relacionado diretamente a fantasioso, mas se refere a algo magnífico, porém real.

\section{Linha 171 - según dicen las madres está como un tren y es cachondo}

$\mathrm{Na}$ mesma oração encontramos duas marcas de oralidade/coloquialidade, que podem ser consideradas gírias, são elas tren e cachondo. As duas se referem ao aspecto físico do médico, haja vista a primeira (tren) significar que o médico está muito bem, com vigor, e a segunda (cachondo) reforçar essa mesma idéia, porém de maneira um pouco mais vulgar, pois se refere ao aspecto sexual, seria o mesmo que dizer que o médico é um "tesão", ou, de maneira atenuadora, dizer que ele é "gostoso".

\section{Linha 195 - Con mis amigos no se corta ni un pelo}

A expressão gíria nessa sentença significa que, na visão de Manolito, sua mãe não gosta muito de seus amigos, apenas os suporta, certamente por serem muito traquinas. Essa gíria nos apresenta a idéia de que a mãe possa não gostar de seus amigos, porém de uma maneira sutil a qual permite ao leitor graduar esse "não gostar", pois tal gíria sugere isso, mas não o explicita. 
A palavra corte pode ser considerada gíria pelo fato de aqui não assumir um significado próximo de divisão, separação (de algo concreto), mas sim de assumir um significado de ruptura, quebra de expectativa, com relação à chegada do avô.

Vemos que os verbos quebrar e dividir, embora pertençam ao mesmo campo semântico, não podem ser tomadas, dentro de determinados contextos, como sinônimos.

Linha 229 - mi abuelo se estaba poniendo un poco pesado.

A gíria pesado significa "desagradável", que, nesse caso, se refere à situação de espera, demora e quebra de expectativa à medida que cada convidado vai entrando e todos se preparam para cantar o "Cumpleãnos feliz". O uso da gíria para expressar o descontentamento deixa subentendidos todos esses aspectos negativos.

Linha 267 - siempre hay un tío que te fastidia la vida

A palavra tío nada tem a ver com grau de parentesco, e sim é usada para referir-se a uma pessoa qualquer, é como dizer um "cara" em português (do Brasil) que, da mesma forma, nada tem que ver com parte do corpo. Normalmente usamos essa denominação para referirnos a alguém que não conhecemos. Embora Yihad seja bastante conhecido, Manolito opta por referir-se a ele como um tio mostrando de certa forma seu desprezo pelo "colega", que sempre o trapaceia, até mesmo em sua própria casa.

\section{Linha 305 - Molaba cien kilos que llegara el verano}

A gíria molar (molaba) significa "gostar muito", cuja intensificação é marcada pela presença do advérbio "muito". Portanto, não se trata apenas do "gostar", mas do "gostar muito", ou seja, do molar.

Embora molar signifique "gostar muito", Manolito o reforça ainda com o uso da expressão gíria cien kilos. É interessante notar que essa relação estabelecida entre grandiosidade/intensidade e algo concreto está presente ao longo de todo o corpus. Acreditamos que o garoto tenha necessidade de usar algo concreto para deixar claro para seu leitor a real a dimensão do que está sendo dito.

Esse efeito de realidade, produzido predominantemente pelo emprego de variantes mais populares, dá maior expressividade ao texto, ou seja, torna-o mais objetivo, real, pois é comum que em uma conversação informal se empreguem tais variantes. 
Sabemos que a escolha lexical está também relacionada ao domínio dos interlocutores, de modo que não devemos nos esquecer de que o livro Manolito Gafotas se destina a um público infanto-juvenil e que, certamente, utiliza um vocabulário menos formal e mais popular.

Percebemos que em nosso corpus se apresenta tanto o registro standard quanto o coloquial; este último exercendo a função de representar a fala e de dar mais dinamismo ao texto. 


\subsection{Análise II - Comicidade}

Nessa parte do nosso trabalho, analisaremos trinta trechos que consideramos mais significativos, por apresentarem "alto grau" de comicidade; tais trechos encontram-se em negrito.

Nosso intuito aqui é identificar, em cada um dos trechos, qual o principal mecanismo desencadeador da comicidade. Dizemos principal pelo fato de encontrarmos, em um mesmo trecho, vários mecanismos que colaboram para a comicidade. Outro propósito de nossa análise é verificar se a oralidade/ coloquialidade está presente nesses trechos e, caso esteja, em que medida é responsável para a produção dos efeitos cômicos no corpus.

Por se tratar de um texto escrito, conforme já mencionado, nos apoiamos basicamente na teoria de Bergson (op. cit.), no tocante ao cômico das palavras, as quais são fundamentais na construção do discurso, pois, de acordo com as palavras selecionadas, pode-se obter esse ou aquele efeito. Por esse motivo, tomamos "emprestado" algumas das denominações empregadas pelo autor para agrupar os elementos desencadeadores da comicidade, tais como transposição e inversão.

Observamos que, juntas, elas desencadeiam vinte das trinta ocorrências de comicidade mais significativas, ou seja, transposição e inversão representam a maior parte das ocorrências cômicas no corpus.

Além da transposição e da inversão, reconhecemos que o corpus também apresenta outros dois elementos que consideramos relevantes para a produção da comicidade. São eles: a organização do discurso e a quebra de expectativa do leitor, que pode ser por meio de um ato, uma palavra, um gesto, entre outros. Sabemos que esses dois últimos elementos permeiam todo o corpus apresentando uma função "coadjuvante" na produção de efeito de sentido cômico. Não obstante, somente em algumas passagens por nós selecionadas eles assumem o papel principal na produção de humor.

O agrupamento dos elementos desencadeadores se dará da seguinte forma:

a) Transposição;

b) Inversão;

c) Quebra de expectativa;

d) Linguagem.

Para cada um dos mecanismos desencadeadores do riso anteriormente citados, agruparemos trechos numerados correspondentes. Para facilitar a leitura, seguiremos a mesma a ordem em que estão dispostos no corpus.

Embora muitas vezes a comicidade possa ocorrer devido ao emprego de apenas "uma ou outra palavra", consideramos importante colocar o trecho todo para melhor compreensão, 
assim o leitor poderá contar ainda com o corpus numerado de acordo com os trechos cômicos em negrito que se encontra anexado ao final do trabalho.

Lembramos ainda que o agrupamento não tem o propósito de estabelecer com exatidão o elemento disparador da comicidade, mas o de apenas sugerir qual possa ser esse elemento, pois, como já havíamos mencionado, a comicidade é produzida por um encontro de fatores e não apenas um único. Em nosso corpus especificamente, podemos dizer que na maioria das vezes há um elemento que pode ser apontado como desencadeador da comicidade, o que não significa a inexistência de outros que complementam esse desencadear do humor.

\subsubsection{Transposição}

Com já mencionamos na parte teórica do nosso trabalho, a transposição consiste em um deslocamento de uma situação produzida em um determinado "lugar" para outro distinto, mesmo que empregando as mesmas atitudes da situação "original", causando, assim, um despropósito nas atitudes e provocando um desvio de comportamento.

Analisemos agora cada um dos trechos que seguem:

Trecho 1- Mi abuelo no quería celebrar su cumpleaños. Dijo que no, que no y que no. Mi madre decía:

- Pero papá, ochenta años no se cumple todos los días.

Gracias a Dios - dijo mi abuelo. Sólo faltaba que ese disgusto se lo dieran a uno cada dos por tres.

Nesse trecho percebemos um desvio de comportamento por parte do avô, que consiste em o avô recusar-se a comemorar algo tão especial, como fazer oitenta anos.

O desvio é reforçado quando é o avô que diz "Gracias a Dios", como resposta ao comentário persuasivo da mãe de Manolito. Tal resposta parece absurda, pois o natural seria que se agradecesse a Deus por chegar a essa idade e não praguejar esse acontecimento; temos, portanto, uma transposição em relação ao agradecimento.

O emprego de frases feitas, entre outras marcas de um texto oral/coloquial, colaboram para a comicidade. Para que esse efeito de sentido seja compreendido, o leitor deve estar atento não somente às questões lingüísticas, mas também a dados culturais que determinam certos padrões, como a comemoração de um aniversário. 
Trecho 2- - i Sí abuelo! Nosotros te lo preparamos, invitas a tus amigos, compramos una piñata... - ya me lo estaba imaginando.

- Y dentro de la piñata podéis meter pastillas para la artrosis, pastillas para la incontinencia, pastillas para la tensión... - mi abuelo estaba por verlo todo negro.

A transposição de situação é aqui o principal elemento causador do riso, pois o avô passa a se referir à festa de aniversário como algo muito ruim e propõe, ironicamente, servir remédios para doenças senis em vez de docinhos de aniversário.

Há também uma proposta ingênua por parte de Manolito, que é transformar uma festa de 80 anos em uma de oito, pois sabemos que não é usual piñatas em festa de idosos, e sim em festa de crianças. Assim, em termos cronológicos, a construção imaginária da festa vai de um extremo a outro.

O paralelismo empregado pelo personagem do avô, para enfatizar a face negativa de uma festa de 80 anos, acaba transformando a piñata em uma farmácia. Ademais, o paralelismo repetido também pode ser visto como uma mecanização, além de ser uma marca de oralidade/coloquialidade.

A repetição também pode reforçar na caracterização de Don Nicolás como um velho "resmungão".

Trecho 3- - Le digo al abuelo de Yihad que venga a mi cumpleaños e se mea de risa. Los viejos no celebran el cumpleaños, eso no se ha visto nunca. ¿ Queréis también que apague ochenta velitas?

- i Sí! - dijimos el imbécil y yo, que a veces estamos de acuerdo.

- Yo apago ochenta velas y me enterráis después de cumpleaños feliz.

Mais uma vez, temos a transposição como geradora da comicidade. Em um primeiro momento, a transposição ocorre devido à pressuposição de Don Nicolás a respeito do comportamento de um amigo velho, que, segundo ele, ao invés de agradecer-lhe o convite, achará muita graça na situação. Portanto, esse amigo apresentaria um comportamento descabido para a situação. Em um segundo momento, a transposição ocorre em função do drama feito pelo avô ao dizer que após apagar as velas morrerá. Tal afirmação proporciona um contraponto, afinal em uma festa de aniversário, devido a sua natureza - comemoração do nascimento -, parte-se do pressuposto de que o tema morte dificilmente aparecerá.

A ironia está presente na fala do avô quando ele pergunta se querem que ele apague oitenta velinhas. Nesse caso, ela se dá devido ao emprego do diminutivo que aqui sugere algo 
frágil ou infantil. Portanto, um velho soprando velinha poderia parecer infantil, embora apagar velas seja algo típico de qualquer aniversário, independente da faixa etária.

O uso de um vocabulário mais vulgar também contribui para a comicidade, pois certamente não teríamos um efeito cômico se o avô dissesse que seu amigo urinaria nas calças ao receber o convite. Essa proposta evoca uma cena ridícula, pois os adultos parte-se do princípio de que os adultos controlem sua urina, caso contrário, grosso modo, temos uma pessoa adulta com comportamento inadequado à sua idade.

Trecho 10- Al día siguiente le abrí las tripas a mi cerdo. Mi cerdo es una hucha de barro. Generalmente la gente rompe el cerdo cuando tiene la hucha llena; pero como yo nunca espero a tenerla llena y siempre quiero abrirla cuando sueno dos o tres monedas porque más no aguanto, mi padre le hizo una ranura secreta en la barriga y todos tan contentos: ni yo tengo que romper la hucha ni ellos tienen que comprarme una cada domingo.

Tenia ciento cincuenta pesetas. No era mucho. La verdad es que sólo llevaba ahorrando un fin de semana; eso no daba ni para comprar las bufandas esas a las que mi abuelo tenía tanto asco. Si hubiera tenido dinero me hubiera gustado comprarle una dentadura postiza. El que la que tiene se la hicieron un pelín grande y como se ponga a comer algo duro es un desastre mundial: acaba por quitarse la dentadura con el trozo de carne clavado en sus dientes postizos.

A transposição está na atitude deslocada do avô, que, segundo Manolito, por ter uma dentadura com defeito, quando come é um desastre, pois diz, de maneira exagerada, que o avô chega ao ponto de deixar a dentadura presa no alimento que estava sendo comido. Percebe-se, portanto, que o desvio de comportamento foge às regras de etiquetas quando se está à mesa, a descrição nos permite imaginar uma cena ridícula.

Outro fato que podemos considerar fora de contexto é o ato de presentear alguém em seu aniversário com uma dentadura. Essa atitude poderia soar de mau gosto, mas, perante sua ingenuidade ao não ver nenhum mal nesse tipo de presente, apenas nos leva ao riso.

A forma como esse trecho foi construído também colabora para a comicidade, uma vez que podemos perceber isso quando Manolito nos conta como seus pais encontraram uma maneira para não Ihe comprar um cofre a cada semana. Outro elemento risível na construção é o fato de ele dizer que o dinheiro que possuía não era muito. Como, em realidade, sabemos que não era quase nada, percebemos aí uma forma atenuadora que o personagem usou para dizer que não tinha dinheiro. 
O humor apresentado aqui é direto, porque não se faz necessário o leitor decodificá-lo. Talvez por ser um humor destinado ao público infantil tenha esse tom "pastelão", pois o emprego de um humor mais elaborado exigiria um grau maior de abstração.

Trecho 15- Mi abuelo se quedó alucinado cuando vino a recogerme al colegio con el Imbécil y se encontró con que todos nos íbamos al médico con él, pero se calló. Está acostumbrado a que le hagamos cosas peores, como aquel día que el Orejones y yo cambiamos una aceituna negra por una cucaracha en el Tropezón. La atravesamos con un palillo de dientes y todo; la verdad es que daba el pego, pero mi abuelo sospechó que no se trataba de una aceituna como las demás cuando vio que a la aceituna se le movían las patas. Bueno, al fin y al cabo las cucarachas son tan típicas en el Tropezón como las aceitunas.

A travessura à qual Manolito se remete é um típico desvio da ordem. A comicidade está presente pelo fato de haver um elemento mecânico sobreposto a algo natural, ou seja, há uma deformidade na situação, que é a colocação da barata em um lugar que não é exatamente o seu. Dizemos exatamente porque, assim como as azeitonas, as baratas também são encontradas naquele bar.

O desvio consiste na troca de uma azeitona preta por uma barata espetada no palito. A semelhança entre ambas, associada ao possível equívoco por conta da distração, soaria bastante natural; e é esse equívoco natural que provocava o riso.

Embora a avô tenha se dado conta da travessura, rimos em função da possibilidade do equívoco.

Trecho 16- Luego pasamos todos juntos a la consulta del doctor Morales, que es el médico de todos mis amigos y cura prácticamente todas las enfermedades y además, según dicen las madres, está como un tren y es cachondo. El doctor Morales es un médico de serie de televisión, en eso está de acuerdo todo el Carabanchel. Nos subimos todos a la camilla con el Imbécil; todo paracía ir muy bien hasta que Yihad empezó a tirarnos camilla abajo; entonces el simpático doctor Morales, ese doctor de serie de televisión, nos dijo que si no teníamos nada que hacer en nuestra casa. El Orejones, que le ha tocado el papel en esta vida de meter la pata, dijo:

- Sí, tenemos que celebrar el cumpleaños de...

No pudo terminar su frase asesina porque se encontró con que cuatro codos se le habían metido en la boca. Eran los nuestros. 
A transposição sugerida é a de comportamento, pois se supõe que em um consultório médico as pessoas que ali se encontram estejam debilitadas por alguma enfermidade, assim como as que acompanham se compadeçam de seus estados, porém o comportamento dos garotos é o de quem está em um parque de diversões, tal é a bagunça que fazem.

O médico, que parece ser considerado um semideus, visto que Manolito diz que o Dr. Morales cura tudo, logo é descaracterizado pela apreciação de seu porte físico, por parte das mães. O fato de os elogios irem de um plano a outro colabora para um efeito cômico.

Outro fato que colabora para a comicidade é a distração do amigo Orejones, que não entende o sentido da bronca em forma de pergunta e quase deixa escapar sobre a festa surpresa. Nessa passagem, temos um elemento mecânico sobreposto ao natural, uma vez que já haviam combinado o natural, não precisando mais tocar no assunto, principalmente na presença do avô, e há um desvio do comportamento esperado por parte do personagem Orejones.

O uso de variante popular, a frase feita e as gírias colaboraram para a comicidade do trecho, pois essa situação, dita de maneira formal, certamente não causaria um efeito cômico.

Trecho17- El caso es que el diagnóstico del médico nos tranquilizó mucho: los mocos de Imbécil no eran graves, eran asquerosos. De repente mi di cuenta de que ya eran las seis y cuarto,cogimos todos a mi abuelo tirándole del chaquetón y lo llevamos casi corriendo hasta mi casa. De vez en cuando nos daba la risa nerviosa, porque la emoción de llevar a un abuelo a un cumpleaños sorpresa sólo se puede comparar a las cataratas del Niágara o al cañon del colorado; lo demás en la vida no es tan emocionante.

A transposição nesse trecho se refere aos sentimentos experimentados pelo garoto, que compara a emoção de levar o avô a uma festa surpresa com à sensação de ver as Cataratas do Gran Cânion. A hilaridade se dá principalmente pelo fato de que seja muito pouco provável que ele tenha visto tal paisagem.

Aqui também se nota que sempre que o garoto deseja enfatizar algo, ele exagera fazendo uso de alguma imagem. Talvez pelo fato de ser um livro infanto-juvenil, os leitores possam compreender melhor o uso enfático por meio de dimensões concretas, o que evidencia a desproporção das comparações.

Trecho 20- Oímos la llave y nos pusimos a cantar como locos y a comer al mismo tiempo. Antes de que Ilegara al salón, Yihad había acabado con las patatas y su vaso de coca cola; y eso que mi casa, como dice mi madre, es una caja de cerillas y uno llega 
pronto a todas las habitaciones. Pero el que entró no era mi abuelo, era el marido de la Luisa que venía con más víveres; tres botellas de vino para los abuelos. Nos llevamos un cortazo y un tortazo. Mi madre dijo que al que volviera a abalanzar sobre la comida le daba un bocadillo para que se lo comiera solo y triste en el parque de Ahorcado. Es una madre sin compasión.

A transposição nesse trecho se dá em relação ao comportamento de um dos convidados, que, ao invés de portar-se bem, por ser uma ocasião supostamente solene, portase de modo raro: a gula de Yihad não permite que ele tenha bons modos, e assim ele segue comendo ferozmente.

A mãe, diante da situação, se irrita com os maus modos das crianças e lhes aplica corretivos na frente dos outros convidados, além de os ameaçar caso não se portem melhor.

Outro fator que desequilibra o ambiente é a comida contada, pois normalmente em uma festa o elemento principal é a comida, a qual, via de regra, é abundante. A graciosidade maior é causada quando relembramos a fala de Manolito, ao se referir à "fastuosa merienda colosal", que, ironicamente, são os sanduíchinhos contados.

Trecho 21- El marido de la Luisa tomó posiciones en el corro que formamos alrededor de la mesa. Volvió a sonar la llave en la puerta y repetimos nuestro Cumpleaños Feliz con la misma energía poderosa de antes. Yihad se siguió metiendo comida en la boca creyendo que mi madre no se daba cuenta, lo que pasa es que a veces decide hacerse la sueca. Si yo fuera Dios la contrataría: ella es capaz de tener sus ojos en todas las partes. Es del tipo de madre camaleónica.

A postura do colega Yihad continua sendo desarmônica em relação ao comportamento esperado em uma festa. A comicidade está no fato de Yihad enganar-se ao pensar que ninguém se dá conta de sua atitude. A mãe, contudo, que, segundo o próprio Manolito, parece possuir superpoderes, entre eles o de adivinhar tudo, percebe a postura de Yihad.

É senso comum achar que as mães sempre "adivinham" o óbvio, como o garoto que não quer tomar banho ou que comeu doces antes das refeições, por exemplo, do ponto de vista infantil, no entanto, não há nada de óbvio nessas "adivinhações”, e isso é hilariante.

Trecho 23- No quedó nada. Se acabó el vino, la casera, las cocacolas. Bajaron a por más, se siguió acabando. Los viejos hacían cola todo el rato para mear; cuando le tocaba al último de la fila, ya tenía ganas otra vez el primero. 
Nesse trecho é apontado um desvio de conduta em relação a uma necessidade física, que é o fato dos avós fazerem fila o tempo todo para usarem o banheiro, numa clara referência à incontinência urinária, comum aos idosos. A graciosidade parece estar no movimento sugerido, ou seja, sair do banheiro e já entrar na fila, como um movimento mecânico.

Dessa forma, não aproveitam a festa, pois quando não estão no banheiro, estão na fila.

Trecho 24- Mi madre sacó la tarta, pero la tarta no se veía: quedaba oculta por ochenta velas. Mi madre bajó las persianas para que el salón quedara iluminado sólo con la luz de las velas. El imbécil se puso a llorar porque decía que le daban miedo la cara de los viejos al rededor de la tarta. A mi abuelo le sobresalían los colmillos a los dos lados de la boca. Estaba realmente espectral, sólo le faltaban unas gotas de sangre por la barbilla.

A transposição se encontra no fato de que os velhos causam medo no pequeno Imbécil, justamente numa situação que, pela sua natureza festiva - portanto, lúdica - prima pela diversão, não pelo medo. A descrição exagerada de Manolito é imaginária e bastante fantasiosa que nos sugere uma feiúra digna de riso.

Trecho 25- Mi madre nos dijo que apagáramos los niños las velas. Gritaron: i Una, dos y tres!, pero Yihad se nos adelantó y las apagó él casi todas. Hasta en las fiestas de tu abuelo siempre hay un tío que te fastidia la vida. Mi madre dijo que en los cumpleaños no hay que pelearse, así que tuve que aguantarme, como siempre. Ahora que lo pienso paso de soplar velas, qué idiotez. Mientras partían la tarta cantamos Es un muchacho excelente, y a mi abuelo se le cayeron dos o tres lágrimas, como siempre que se brinda, que el reloj de la Puerta del Sol toca para las uvas o que sale gente en la televisión muriéndose en la guerra. El abuelo de Yihad dijo que mi abuelo tenía que decir unas palabras.

A transposição mais uma vez se refere ao desvio de comportamento. O colega Yihad, como sempre, é mal educado até nas festas alheias. Apesar de a mãe de Manolito ter combinado que todas as crianças da festa apagariam juntas as velinhas, Yihad se antecipa e as apaga à frente de todos, chamando a atenção para si.

A comicidade da cena é produzida em função da construção da oração que nos possibilita mais de uma leitura. Quando Manolito afirma que sua mãe diz que em festas não se pode brigar, podemos entender que a mãe determina que o garoto tenha um comportamento pacífico somente em festas, e que, em outros lugares, revidar seria permitido; é como se a mãe 
mascarasse seu real desejo o qual, certamente, o mesmo compartilhado pelos leitores, que é colocar o "insuportável" Yihad no seu devido lugar, aplicando-Ihe um corretivo.

Se considerarmos a segunda leitura da oração, em relação à possível postura da mãe, teríamos um desvio de comportamento de sua parte, pois temos uma pré-concepção de que as mães, em qualquer situação, devem impedir que seus filhos briguem.

Trecho 26- Mi abuelo decía que no, que no y que no, pero se hizo otro coro del Papa para gritar: “QQue hable, que hable!” Entonces mi abuelo dio la noticia, la mejor noticia de la temporada teniendo en cuenta que el real Madrid como siga así no va a ganar la Liga. Mi abuelo anunció:

- Siempre he dicho que pensaba morirme en 1999, unos días antes de que acabara el siglo $X X$, bueno, pues he pensado que voy a probar dos o tres años del siglo $X X I$.

A transposição de valores é aqui sugerida quando Manolito diz que a melhor notícia da temporada foi o seu avô dizer que não iria morrer tão logo, porém essa notícia só é considerada a melhor pelo fato de Manolito saber que não receberá a notícia de que seu time fora campeão. A valorização do futebol pode ser percebida. O garoto usa o termo temporada por últimos tempos, ou seja, emprega um vocábulo que normalmente serve para denominar um período de disputas esportivas.

Trecho 27- El suelo estaba lleno de patatas y de cocacola. Seguro que por la noche estaría otra vez brillante como un espejo, porque mi madre es como esas madres de los anuncios, pero con la casa mucho más pequeña.

A transposição parece sair de um plano irreal para o real, ou seja, a postura da mãe é igual à das donas-de-casa, que aparecem nas propagandas, mas com algumas diferenças: as casas dos anúncios são enormes, ao passo que a casa de Manolito é muito menor, outra diferença está na pessoa que faz a limpeza da casa. Certamente alguém que possui uma casa como aquelas exibidas nos anúncios paga uma pessoa para fazer o serviço de limpeza, pois nos parece óbvio que aquela mulher linda e bem cuidada não execute tal serviço. Entretanto, na casa do garoto, é sua mãe quem faz a limpeza, inclusive, segundo ele, ela deixa tudo brilhando. Por certo, ela o faça porque, além de não ter condições para contratar uma empregada, sequer possui uma casa tão grande e bonita como as que aparecem nas propagandas.

A comicidade da situação está no fato de que somente as coisas ruins da comparação feita por Manolito é que são verdadeiras. 
A referência feita ao anúncio revela um dado cultural relevante, que é a forte presença da TV na vida dos espanhóis, outras passagens no corpus também evidenciam isso.

trecho 29- El que se había dormido era el Imbécil, tenía la cabeza apoyada en mi abuelo y los pies en mí. Siempre me toca soportar lo peor de las personas. El Imbécil es muy pequeño, pero ya le huelen los pies; en eso ha salido a mi padre. Yo también he salido a mi padre: en las gafas y en el nombre.

A transposição está no fato de uma criança apresentar mal odor nos pés, pois consideramos ser mais comum esse odor em homens adultos.

Manolito diz que, em relação a isso, Imbécil puxou a seu pai e que ele também possui uma semelhança com seu pai, aliás, duas: a necessidade de óculos e o fato de os dois possuírem o mesmo nome. Percebemos, então, que a semelhança que ambos têm com o pai se referem a aspectos negativos.

Quando Manolito diz que sempre tem de suportar o pior das pessoas, pensamos automaticamente em algo relacionado ao caráter das pessoas e não ao mal cheiro de seus pés. A comicidade se dá pelo fato de o garoto considerar isso como uma das piores coisas em uma pessoa, quando na realidade sabemos que há coisas muito piores.

Trecho 30- Todo estaba tan quieto como en una película que echaron en la tele en la que un abuelo y un niño se quedaban los últimos en el cementerio después del entierro de uno que era negro. Pero esto era mucho mejor porque en la película de mi vida no habría ningún muerto de momento, me lo había prometido mi abuelo.

A comparação entre as cenas é absurda, pois Manolito se recorda de uma morte, ou seja, algo ruim para referir-se a uma sensação boa que está vivenciando. Essa gafe, entre outras presentes no corpus, revela a ingenuidade do personagem. Ao perceber o despropósito de sua comparação, trata de justificá-la com o fato de que a sua vida era muito melhor, pois ninguém havia morrido. Ao invés de parar por aí com suas justificativas, acrescenta um de momento, que significa "ao menos por enquanto", ou seja, cada vez o garoto faz um comentário pior que o outro, quando a intenção é dizer algo bom.

\subsubsection{Inversão}

Com já mencionamos anteriormente, a inversão é basicamente a troca de papéis.

Encontramos em nosso corpus seis trechos nos quais há ocorrência de inversão, todas elas diretamente relacionadas ao comportamento. 
Trecho 7- Hay veces en la vida que me precipito a la hora de pedir disculpas, $y$ ésta había sido una. Por primera vez en la historia no me llamaba para echarme una bronca terrorífica; me dijo que iba a celebrar el cumpleaños de mi abuelo por encima del cadáver de quien fuera.

- Pero si él no quiere...

- Lo que él quiera o no quiera a nosostros no nos importa.

A ingenuidade de Manolito pode ser uma das causas do riso, pois tal ingenuidade não permitiu que ele ouvisse a sua mãe.

Como o garoto já esperava uma bronca, foi logo se desculpando, porém, dessa vez, a mãe o chamara por outro motivo. Diante disso, o ato de pedir desculpas, considerado um ato positivo, assume um aspecto negativo, pois tal atitude evidencia que Manolito havia feito uma travessura.

Outro fato risível é a suposta inversão de valores por parte da mãe, em relação ao seu desejo de fazer a festa. Tal inversão ocorre devido à contradição do texto, considerando que a mãe queria fazer uma homenagem ao avô, não se importando com a vontade do aniversariante. Como o objetivo da mãe é agradar o avô, a oração parece ser contraditória, daí o trecho se caracterizar como cômico.

Trecho 12- Pensé que a lo mejor no les apetecía venir a un cumpleaños de un abuelo... ; Sí, todos dijeron que sí! Mis amigos son capaces de ir al cumpleaños de Fredy Crouger con tal de tomar tarta y coca cola. Les dije que entonces se tendrían que venir todos antes a la seguridad social al llevar al imbécil al médico. "Pues bueno, pues vamos", dijeron.

Nesse trecho, a inversão de valores ocorre em função dos interesses particulares dos garotos, pois se a expectativa é de que quem vai a festas de pessoas queridas vai para compartilhar momentos importantes, aqui, no etanto, os garotos vão para se beneficiarem, comer bolo e tomar coca-cola. Os glutões amigos de Manolito iriam até mesmo à festa do monstruoso Freddy Crouger - o exagero empregado aqui permite ao leitor imaginar a cena absurda de um monstro comemorando um aniversário e isso certamente é bastante cômico.

Trecho 13- - Mi abuelo quiere saber por qué tu abuelo no le ha invitado a su cumpleaños

- Es que piensa que lo de invitarse a los cumpleaños no es de viejos. 
- Pues le va a salir el tiro por la culata poque estoy harto de invitarle al Tropezón para que ahora me deje a mí tirado en la calle. ¿ A qué hora es el cumpleaños de las narices?

São várias as inversões nesse trecho. Todas, de alguma forma, produzem comicidade. A primeira está no fato de $\mathrm{D}$. Nicolás não convidar seus amigos velhos por considerar isso ridículo, porém, para compensar a ausência de amigos velhos, Manolito resolve convidar os seus próprios amigos, que são crianças. Com isso, a cena da festa fugiria dos padrões esperados, visto que, em linhas gerais, espera-se que em festa de velhos predominem velhos e que em festa de crianças predominem crianças.

Outra inversão está no fato de o melhor amigo de D. Nicolás não ter sido convidado e ele próprio se convidar. Porém, não bastando essa atitude, ao invés de agradecer o fato de poder ir à festa, passa a desdenhá-la.

Essas contradições rompem com nossas expectativas, produzindo, por conseguinte, efeitos humorísticos.

Trecho 19- Era verdad. Al abuelo de Yihad se le había ocurrido traerse a cuatro abuelos más de los que van a jugar al chinchón al Club del Jubilado. También estaba la Luisa, pero eso no es ninguna novedad; la Luisa siempre está en mi casa, menos a la hora de dormir, que se baja con su marido por si a Bernebé se le disloca el peluquín mientras ronca. Mi madre nos colocó al rededor de la mesa. No se podía tocar ni un panchito porque estaban contados y mi madre se pone nerviosas cuando hay mucha gente y poca comida. Todo estaba preparado para cantar el Cumpleaños Feliz cuando el abuelo asomara por la puerta.

Inversão aqui se refere a algo concreto, e não comportamental como nos casos anteriores, pois há muita gente e pouca comida, o que acaba constrangendo a anfitriã, provocando novamente o riso.

Outro elemento muito engraçado é a referência de Manolito à peruca de Bernabé. Com base em sua descrição, podemos imaginar a cena de alguém roncando exageradamente a ponto de fazer com que sua peruca se desloque da cabeça. É um humor meio grotesco, mas leva à hipótese de que tais cenas, por serem repetidamente apresentadas em desenhos animados, são incorporadas pelas crianças, as quais certamente percebem o intertexto existente na descrição.

\subsubsection{Quebra de expectativa}


Tomamos aqui um elemento que consideramos quase que inerente à comicidade, que é a quebra de expectativa, ou seja, quando outrem nos apresenta algo totalmente diverso do que esperávamos. Vale ressaltar que nem todas as surpresas, por outro lado, são cômicas, mas somente aquelas que se apresentam na justa medida.

A quebra da expectativa quase sempre está associada a outros mecanismos disparadores do riso. Às vezes, essa quebra se mostra coadjuvante, às vezes, é protagonista do processo desencadeador do efeito cômico.

Nos trechos que seguem, consideramos a quebra de expectativa como o principal elemento causador do riso.

Trecho 4- - Pues dinos lo que quieres que te regalemos - mi madre no se da por vencida tan facilmente.

- i Nada! No tengo nada que celebrar, no tengo amigos y no tengo ganas de cumplir ochenta años; lo único que tengo son bufandas de los cumpleaños anteriores.

Dicho eso mi abuelo se metió en el cuarto de baño para ponerse los dientes postizos, porque se iba a tomar el sol con el abuelo de Yihad. Mi abuelo no es de los que les gusta tomar el sol sin los dientes. Cogió la puerta y se fue. El imbécil e yo nos quedamos con el cumpleaños en la boca.

Nesse trecho se espera que o avô possa fazer qualquer coisa no banheiro, ou até mesmo não fazer nada, ficando apenas trancado fazendo birra como uma criança mimada, porém nunca imaginaríamos que, depois de uma discussão, ele entraria no banheiro e apenas colocaria a dentadura para dar um passeio. A atitude do avô é inesperada e quebra a expectativa do leitor.

Ao revelar o que o avô fora fazer no banheiro, houve um relaxamento em uma situação aparentemente tensa.levando o leitor ao riso

Trecho 9- Antes de salir de la habitación mi madre dijo:

- Y como me entere de que vuelves a tirar polvorones por la terraza, vas tú detrás.

Ya sabía que era imposible entrar en la habitación de mi madre y que no te la cargaras por algo. Bueno, había salido sano y salvo, sin cicatrices, no me podía quejar.

Como a mãe já havia dito que não chamava Manolito para dar-lhe uma bronca, tanto o garoto quanto o leitor crêem que a bronca não será aplicada, visto que a mãe explicita que não o chamou para isso. 
Podemos dizer que a atitude da mãe nos surpreende duplamente, primeiro por não dar a bronca em Manolito, quando ele confessa sua travessura, segundo por voltar atrás e aplicarIhe a bronca quando pensávamos que ela já havia se esquecido da confissão do garoto. Há um vai-e-vem de quebra de expectativa, pois ora se espera a bronca e ela não ocorre ora, quando não se espera mais, ela acontece, causando o efeito cômico no trecho.

Trecho 11- ¿ A que no sabes lo que vi de repente, sin previo aviso? Una dentadura de Drácula. No tenía dinero para una dentadura de dentista, pero si para comprarle a mi abuelo una de Drácula. Me gastaría el dinero a mi abuelo. En ese momento fui la mejor persona que he conocido en mi vida, sin exagerar. Fui como ese niño del cuento que es capaz de morir por salvar a su abuelo. Menos mal que yo no me veía en la obligación de morir, porque, la verdad, eso me lo hubiera pensado dos veces.

Nessa passagem, temos a sensação de que o garoto tenta fazer com que o leitor se surpreenda, assim como ele se surpreendeu, com o presente que poderia comprar a seu avô. Por esse motivo, incita que o leitor adivinhe o que certamente comprará de presente para seu avô.

O fato de o garoto querer presentear o avô com uma dentadura nos surpreende, pois não é usual que se presenteie alguém como uma dentadura, a menos que seja uma brincadeira. No entanto, o garoto refere-se à dentadura como se fosse um presente comum. Essa naturalidade empregada por Manolito ao considerar tal presente algo comum é hilariante, tornando-se mais ainda quando o leitor se dá conta de que o absurdo relativo ao presente não pára por aí. Não se trata apenas de uma dentadura, mas de uma dentadura de brinquedo, mais especificamente de uma dentadura de vampiro. Vemos que a sucessão de surpresas em relação ao presente vai causando um humor cada vez mais intenso.

Outro fator cômico presente é a contradição nos valores de Manolito. Em um primeiro momento, ele se considera a melhor pessoa do mundo por abrir mão de comprar algo para si em função de presentear o avô; refere-se a uma passagem de um filme, mas, não obstante, logo trata de deixar claro que pensaria duas vezes antes de morrer para salvar seu avô. Nesse trecho temos a sensação de que sua máscara cai e o "nobre" Manolito volta a ser o garoto comum.

Trecho14- El abuelo de Yihad estaría a las seis con los dientes puestos en mi casa. Allí se encontraría con mis padres, la Luisa y su marido. Mi madre se preguntaría a sí misma: “ ¿ Y a éste quien le ha invitado?"Pero se lo callaría porque delante de las personas de fuera siempre es muy educada, como Lady Di. 


\section{La fastuosa merienda colosal estaría esperándonos en la mesa.}

O garoto inicia o trecho falando da postura dos convidados e logo passa a falar da comida. Manolito passa de um assunto a outro sem se dar conta de que está tratando de coisas diferentes, não há uma pausa para começar a tratar do segundo item (comida). Temos a sensação de que, para o garoto, convidados e comida pertencem ao mesmo campo semântico, simplesmente pelo fato de todos estarem na festa.

A construção desse trecho não permite ao leitor imaginar que haveria essa brusca mudança de temas, até mesmo porque, até então, Manolito vinha enumerando as várias pessoas que estariam na festa, inclusive descreve, durante a expectativa, como se comportariam; de repente, muda o discurso para falar da comida, que, diante da forma como é caracterizada, parece pertencer a um grau superior.

A imaginação do garoto, com relação à postura de sua mãe, diante da situação de descrevê-la, inclusive o que ela pensaria, comparando-a com a princesa Diana, como forma de elogio, revela seu carinho por ela, embora também colabore para a comicidade.

Trecho 18- Subí con mis amigos a casa. Mi madre abrió la puerta y se quedó mirando:

- ¿ Y todos estos?

Con mis amigos no se corta ni un pelo; los trata igual de mal como si fuera sus hijos.

- Como el abuelo no quería un cumpleaños lleno de viejos le he traído a mis amigos.

- No importa - esto lo decía mi madre con tono sospechoso - tenemos niños, viejos... Es un cumpleaños para todos los públicos.

O trecho é cheio de surpresas. Como já mencionamos, é a mãe que se surpreende ao ver tantas crianças, as quais ela certamente não contava com a presença. Logo, é o leitor que se surpreende com o fato de Manolito dizer que sua mãe trata seus amigos da mesma que trata seus filhos. $O$ garoto quebra a expectativa do leitor ao acrescentar nessa mesma oração um fator negativo, pois diz que a mãe trata tão mal os amigos dos filhos quanto os filhos. $O$ modelo de frase consagrado que o leitor tem em mente é "tão quanto". Entretanto, o modelo sofre uma variação negativa e esta nos é transmitida por Manolito, como se não tivesse sofrido nenhuma mudança. 
A naturalidade com que o personagem transmite o "modelo alterado" nos dá a impressão de que o "modelo é autêntico". A mudança ocasionada na oração rompe com a expectativa do leitor e produz um efeito cômico.

Trecho 28- Mi abuelo se había bajado todas sus bufandas en una bolsa para mirarlas de vez en cuando. Yo hago lo mismo con mis regalos de Reyes: me los bajo todos al parque del Ahorcado para que no se separen de mí todo el día. Estábamos sentados en el único banco del parque del Ahorcado que no está roto; es el banco donde se echan la siesta por la mañana todos nuestros abuelos.

A atitude do avô é duplamente inesperada, primeiro porque assume uma postura de criança, ao olhar seus presentes no parque, e a segunda é apreciar a bufandas (cachecóis), que ele havia desdenhado tanto. A situação contraria tudo o que o avô havia dito a respeito dos indesejáveis cachecóis; é a forma como essa contradição nos é apresentada que nos causa graça.

\subsubsection{Linguagem}

Nessa parte do nosso trabalho, tomamos para análise quatro trechos em que a comicidade está presente, ainda que ela tenha sido desencadeada, não por nenhum dos elementos anteriormente mencionados, mas apenas pela forma como esses trechos estão escritos, ou seja, a comicidade presente nos trechos que seguem foi produzida pela linguagem. Indiscutivelmente, se tivessem sido escritos de outra maneira, as situações apresentadas certamente não produziriam o mesmo efeito.

Como se sabe, em todo o corpus a linguagem é um elemento fundamental para a produção de efeitos de sentidos cômicos. Nesses trechos, porém, consideramos que a linguagem é que exerce um papel determinante, daí ser vista como principal produtora da comicidade.

Trecho 5- Yo Hasta ese momento no había conocido a nadie que no quisiera celebrar su cumpleaños. Incluso mi madre, que desde hace muchos años sólo quiere cumplir 37, lo quiere celebrar, y lo avisa muchos días antes para que mi padre se acuerde y le compre un brillante, un visón o una batidora con unas cuchillas mortales, que es lo que al final acaba comprando siempre.

A comicidade nesse trecho é causada pelo fato de Manolito revelar que sua mãe, assim como "todas" as mulheres, não quer envelhecer; por isso, mentem a idade. Lembramos que para haver compreensão da comicidade nesse trecho é necessário entender um fator cultural, 
que parece pertencer ao universo feminino em boa parte das culturas, que é o fato de as mulheres quererem se manter sempre jovem.

Podemos dizer que há um paradoxo na postura da mãe, porque quer fazer aniversário, inclusive avisa para que todos se lembrem, mas não quer envelhecer.

Os vocábulos incluso (inclusive) e sólo (somente) marcam o texto de maneira que seria compreensível alguém, como a mãe de Manolito, não querer comemorar o aniversário, porém até mesmo ela 0 quer. Desse modo, os vocábulos, funcionam como operadores argumentavivos, marcanado a raridade que é o fato de alguém não querer celebrar seu aniversário.

O fato de a mãe ter de fazer com que seu marido se lembre de comprar-lhe um presente revela um desvio de comportamento de ambos, já que ele, por não se lembrar; ela, por ter de fazê-lo se lembrar. Apesar de a mãe sempre dar pistas sobre o presente dos seus sonhos, sempre acaba ganhando, para sua decepção, uma batedeira. Os vários desvios e a forma como estão descritos produzem o humor no texto.

Trecho 6- La madre imprevisible no volvió a nombrar el cumpleaños de mi abuelo, y el famoso día A ( A de Abuelo) se acercaba peligrosamente. La víspera de aquel miércoles misterioso, mi madre le llamó a su cuarto y cerró la puerta. Yo me eché a temblar inmediatamente y le dije...

A estrutura empregada para narrar o plano da festa surpresa ganha um toque de mistério, deixando no ar um clima de suspense, garantido principalmente pelo advérbio peligrosamente ("perigosamente") e pelo adjetivo misterioso. A referência ao clichê dia D, para denominar um acontecimento importante, é substituído por famoso dia $A$, o qual, para que não haja nenhuma dúvida em relação ao intertexto, segundo o próprio Manolito, em tom conversacional, tem a inicial de abuelo.

Para que se capte a comicidade nesse trecho, é necessário que o leitor compreenda a alusão contida em dia $\mathrm{A}$, pois somente a explicação de Manolito não garante o riso.

Trecho 8- Mientras nosotros estábamos en el médico, mi madre iría al súper a comprar provisiones para la fastuosa merienda colosal.

Nesse trecho, a graciosidade está basicamente na escolha dos adjetivos exagerados que supervalorizam o lanche da tarde. Temos a impressão de que, na cabeça de Manolito, se não houver exagero não ficará claro para o leitor que se trata de um especial lanche da tarde, 
tão importante para ele, que encontramos no corpus outras duas citações exageradas em que o garoto também denomina o lanche como fastuosa merienda colosal.

Trecho 22- Nos volvimos a colocar en nuestras posiciones, comíamos el queso sin hacer ruido para que al entrar mi abuelo no se percatara que su casa estaba invadida por miles de personas. Pasó un rato..., y al tercer rato los abuelos empezaron a pedir sillas porque, la verdad, mi abuelo se estaba poniendo un poco pesado.

A comicidade na construção do trecho se dá principalmente pelo fato de o garoto enumerar os momentos que esperavam seu avô para Ihe fazer a surpresa.

As reticências empregadas, nesse caso, nos indicam que o tempo foi maior que um momento. Outro indício disso é o fato de Manolito enumerar os momentos. O garoto menciona o primeiro e, mesmo não mencionando o segundo momento, diz que no terceiro momento já estavam cansados de esperar. Por outras palavras, a enumeração indica de forma "quase concreta" que o tempo de espera foi longo.

É comum dizermos que se passou um momento, mas não dois ou três momentos, como se refere Manolito. Acreditamos que sua intenção é a de dizer que seu avô estava demorando, mas se simplesmente declarasse isso, a graça se perderia.

Analisado todo o corpus, podemos perceber que a comicidade em cada um dos trechos selecionados, embora tenha sido desencadeada por um elemento principal, vários outros elementos também colaboraram para a sua produção. Além disso, em todos os trechos selecionados, são evidentes as marcas de oralidade/coloquialidade, de modo que podemos afirmar que essas marcas também colaboraram para o efeito de sentido cômico no corpus. 
Por meio da análise feita, pudemos perceber que é possível reconstruir um discurso oral/coloquial através de um texto literário infanto-juvenil escrito.

Para que essa reconstrução ocorresse, em nosso corpus, houve necessidade de um alto nível de elaboração, pois reconstruir um texto oral não se trata apenas de empregar expressões ou vocábulos normalmente utilizados na fala, mas sim de um cuidadoso planejamento em que vários elementos da língua oral/informal atuam juntamente com uma estruturação própria desse tipo de modalidade lingüística, além do cuidado de não desrespeitar os padrões da modalidade escrita.

\subsection{Sobre a coloquialidade}

Empiricamente, antes de analisarmos o corpus, já havíamos percebido a presença da oralidade no texto, pois, ao lê-lo, tínhamos a impressão de que alguém nos contava uma história. Diante disso, buscamos quais eram as marcas que caracterizavam um texto oral, e, então, tratamos de reconhecer tais elementos.

Acreditamos que Elvira Lindo, autora do texto, observando cuidadosamente situações reais de fala, reconstruiu um universo no qual o emprego de determinadas expressões e o uso do registro coloquial colaboraram para a verossimilhança no corpus.

Observamos que a forma empregada para reconstruir um texto oral contou com vários elementos lingüísticos e culturais inter-relacionados, a fim de que a "imitação" parecesse natural.

Nas tabelas em que dispusemos as marcas de oralidade presentes no corpus, foi possível constatar a presença de gírias, expressões fixas, variantes populares, marcadores conversacionais, repetição, diminutivo e aumentativo e qual a recorrência de cada uma delas.

Percebemos que tais elementos não marcavam o texto apenas oralmente, mas também de forma coloquial e que, quando empregado, cada um deles exercia uma função específica dentro do texto.

Com relação aos elementos lingüísticos, mais especificamente as marcas de oralidade/coloquialidade, percebemos que as gírias/variações populares, expressões fixas e marcadores conversacionais foram as marcas mais recorrentes no corpus, nossa pesquisa não tratou apenas de quantificá-los, mas demonstrar que seus usos estão diretamente relacionados ao efeito de oralidade/coloquialidade que se deseja produzir, visto que essas marcas são quase que exclusivas do discurso oral/coloquial. 
Sabendo que esses elementos são tipicamente orais, concluímos que, quando empregados na escrita, eles têm a função de marcar lingüisticamente um grupo social, uma época, um país.

Como nosso corpus se trata de um texto infanto-juvenil, encontramos marcas lingüísticas que representam esse universo infantil dentro de um universo sociocultural maior. São elas:

- Estrutura simples da narrativa, uso de gírias tipicamente infantil, além dos jogos de palavras que exploram a sonoridade de forma lúdica.

- O uso de diminutivos que marcam o texto afetivamente e produzem efeitos atenuadores e de aproximação entre os interlocutores.

- O aumentativo, por sua vez, exerceu a função de intensificador em determinadas passagens do texto.

- As expressões fixas empregadas no corpus também revelaram um aspecto da língua oral/coloquial que colabora pra a dinâmica dessa modalidade, pois tais expressões são de fácil decodificação, o que torna a compreensão rápida.

- Os marcadores interacionais deram o tom conversacional ao texto, o que tornou possível a aproximação dos interlocutores.

- A repetição, além de garantir a comicidade em algumas passagens, também revela um traço da língua oral, pois ela é um recurso comumente empregado na fala, seja para enfatizar, seja para retomar e dar prosseguimento ao discurso.

- O emprego de variantes mais populares evidenciou o universo sociocultural representado, pois o uso dessas variantes, além de aproximar os interlocutores devido ao tom informal, também revelaram que esse é o único registro dominado pelo narrador e, por conseguinte, por todo o grupo de marginalizados que ele representa.

Também não deixamos de observar que, embora o universo representado no corpus seja o de uma classe social economicamente desfavorecida, a autora emprega o registro coloquial, porém sem intervenções na língua empregando erroneamente palavras ou estruturas, denominadas por Briz (op. cit.) como vulgarismos. Acreditamos que isso ocorra principalmente por se tratar de um livro destinado ao público infanto-juvenil, ou seja, um público em formação a quem tais intervenções poderiam influenciar negativamente.

O corpus apresenta uma forma narrativa que permite ao leitor, além de imaginar cada cena, ainda "interagir", de certa forma, com o narrador, uma vez que este, através da linguagem, se mostra muito próximo.

\subsection{Sobre a comicidade}


Ao analisarmos os aspectos discursivos produtores de efeitos de sentido cômicos, observamos que:

- As situações que apresentam o cômico se baseiam em aspectos negativos, tais como: mau comportamento, pobreza, doença, velhice, morte; que, de certa forma, todos eles fogem de um padrão desejado.

- A maior parte das cenas risíveis está associada a atitudes que podemos considerar grotescas, indesejadas, desproporcionais ou escatológicas.

- Percebemos que o riso presente no texto se universaliza ao transpassar os limites do contexto e se intensifica quando as "regras" sociais são burladas ou subvertidas.

- Em relação à organização dos elementos lingüísticos, eles colaboraram para o efeito cômico no corpus, podendo-se dizer que o corpus apresenta uma comicidade oral, pois a forma de descrição das situações nos remete a uma língua sonora, juntamente com uma cena "visual" cômica.

- Percebemos que não é possível delimitar com exatidão a função de cada um dos elementos humorísticos, pois todos eles parecem estar divididos apenas por uma linha tênue, por isso interagem.

Consideramos que o texto não apresenta uma única via humorística, mas várias, que se apóiam na linguagem.

Assim, as atitudes que registram o riso transcendem o universo infantil, pois a percepção do personagem Manolito é a de um adulto que vê com certa tristeza esse universo infantil, sem sonhos e sem fantasias, pois não é possível imaginar para esse grupo representado por Manolito um mundo além da pobreza, da mediocridade e da ingênua concepção do que possa ser felicidade (comida e futebol, por exemplo).

A leitura da obra de Elvira Lindo possibilita uma leitura ingênua, infantil que se resulta hilariante, mas deixa naqueles não tão "infantis" um olhar melancólico produzido por essas crianças-adultas que, desde muito cedo, percorrem o caminho das margens.

Pelo fato de todos os trechos considerados cômicos apresentarem marcas de oralidade/coloquialidade, podemos afirmar que ela está inerente à comicidade, visto que "esse mesmo texto" escrito de maneira formal certamente não produziria os efeitos cômicos aqui produzidos.

Por fim, embora os temas escolhidos para nossa pesquisa tenham sido considerados "temas menores", acreditamos que, na atualidade, tanto a coloquialidade quanto o humor contam com vários estudos que os valorizam.

Diante disso, esperamos que nossa pesquisa possa futuramente contribuir com esses estudos. 


\section{BIBLIOGRAFIA}

\section{Bibliografia Geral}

Alcoba, S. (org.) La oralización, Barcelona: Editorial Ariel, 1999.

Almeida, F.A. Linguagem e humor: comicidade em Lês Frustres de Claire Bretécher. EDUFF. Rio de Janeiro, 1999.

Arlt, Roberto. Obra Completa, Buenos Aires: Ed. Carlos Lohlé, 1981. , Aguafuertes porteñas. Buenos Aires, vida cotidiana. Buenos Aires: Alianza, 1993. Aguafuertes porteñas: cultura y política. Buenos Aires: Losada, 1992. El crimen casi perfecto, Buenos Aires: Clarín, 1994.

Authier, Jacqueline. Hétéfogénéité montrée et hétérogénéité constitutive: éléments pour une approche de l'autre dans le discuours, DRLAV (26), 91-151, 1982.

Bakhtin, Mijail, La cultura popular en la Edad Media y el Renacimiento. Barcelona: Barral Editores, 1971.

Marxismo e Filosofia da Linguagem. Trad. de Michel Lahud e Yara F. Vieira. São Paulo: Ed. Hucitec, 1999.

A cultura popular na Idade Média; o contexto de François de Rebelais. Trad. Yara Frateschi. São Paulo: Hucitec Brasília Editora UNB, 1996.

Problemas da poética de Dostoievski. Rio de Janeiro: Ed. Forense Universitária, 1981.

Questões de Literatura e de Estética. A teoria do Romance. São Paulo: Unesp/Hucitec, 1988.

Baron Carvais, A. La historieta. México:Fondo de cultura económica,1989.

Barros, D.L.P. Enunciação e língua falada. In: Dino Preti e seus temas - Oralidade - literatura mídia - ensino. São Paulo: Cortez, 2001.

Barros, Diana Luz Passos de. Dialogismo, Polifonia e Enunciação: In Barros, Diana L.P. e FIORIN, José Luiz (orgs.) Dialogismo Polifonia e Intertextualidade. São Paulo: EDUSP, 1994.

Barthes, R. et alii. Lingüística e Literatura. Lisboa: Edições 70, 1980. O prazer do texto. São Paulo: Perspectiva, 1987. . O rumor da língua. São Paulo: Brasiliense, 1984.

Benveniste, E. Problemas de lingüística geral, São Paulo: Comp. Ed. Nacional/Edusp, 1966.

Berg, W. B \& Schäffauer, M. Oralidad y Argentinidad - Estudios sobre la función del lenguaje hablado en la literatura Argentina. Tübingen, Gunter Narr Verlag Tübingen, 1997.

Bergson, H. O riso - Ensaio sobre a significação do riso 2. ed. Rio de Janeiro: Zahar, 2000. Blanchot, M. O espaço literário, Rio de Janeiro: Rocco, 1987. 
Blühdorn, Hardarik. The relacion between pragmatics, semantics and grammar and the notion of linguistic coherence. In: S. European Journal for Semiotic Studies 10/1-2, 25-71. Coerência no discurso e na cognição. Manuscrito. São Paulo: USP, 1999.

. Codificação de informação espacial no alemão e no português do Brasil: As posições e Advérbios como meios para especificar relações estáticas. São Paulo: Humanitas,2000.

Zur Semantik der conjuktion als. Paradigmatische und Syntagmatische Aspekt. In: Hetschel, Elke (org.). Particulae collectae. Festschrift für Haral Weydt zum 65. Geburtstag. Linguistik online 13, 11-53, 2003.

Borges, J.L. El idioma de los argentinos. Buenos Aires: Peña Del Giudice, 1942.

Bordieu, P. La distinción, el critério y bases sociales del gusto. Madrid: Taurus, 1988. . O poder simbólico, Lisboa: Difel, 1989. Sociologia y cultura. México DF: Grijalbo, 1984.

Brait, B. As vozes bakhtinianas e o diálogo inconcluso. In: Dialogismo, polifonia, intertextualidade. São Paulo: Edusp, 1994. Ironia em perspectiva polifônica. Campinas: Editora da UNICAMP, 1996.

Braw, G. e YULE, G. Discousi analysis. Cambridge: University Press, 1983.

Brandão, Helena H. N. Introdução à análise do discurso. Campinas: Editora da UNICAMP, 1993.

Breal, M. Ensaio de Semântica. Trad. Eduardo Guimarães. São Paulo: EUDC/Pontes, 1992.

Briz, A. El español coloquial: Situación y uso. Madrid: Arco/Libros, 1998. . El español coloquial en la conversación. Barcelona: Editorial Ariel, 2001.

Candido, A. Mundo Desfeito e Refeito. Cadernos de Estudos lingüísticos, № 22, Universidad de Campinas, IEL, Campinas, Jan./Jun.1992, pp.41-45.

Carricaburo, Norma: El voseo en la literatura Argentina. Madrid: Arco Libros, 1999.

Casullo, F. Diccionario de vocês lunfardas y vulgares. Buenos Aires: Plus Ultra, 1988.

Castilho. A.T. de. A língua falada culta na cidade de São Paulo: Materiais para seu estudo.São Paulo :Humanitas, 1987.

Cervoni, J. A. Enunciação. São Paulo: Ática,1989.

Coelho, Nelly Novaes. Panorama histórico da literatura infantil/juvenil. $3^{\mathrm{a}}$. ed. São Paulo: Quirón, 1985.

Cortázar, J. Prólogo a la Obra Completa de Roberto Arlt. Buenos Aires, Carlos Lohlé, 1981.

Coseriu, E. El hombre y su lenguaje - Estudio de teoría y metodologías lingüísticas, Madrid, Gredos, 1977. 
Culler, J. La poética estructuralista. El estructuralismo, la lingüística y el estudio de la literatura, Barcelona, Anagrama, 1978.

Dascal, M. (org.) Fundamentos Metodológicos da Lingüística. volume 3 - semântica. Campinas: Ed. do autor, 1982.

Ducrot, O. O dizer e o dito, Campinas, Pontes Editores, 1987. O Dizer-não dizer, princípios da semântica lingüística. São Paulo: Cultrix, 1977.

Eco, U. Conceito de Texto, São Paulo, Edusp, 1984.

Fiorin, J.L. As Astúcias da enunciação. As categorias de pessoa, espaço e tempo, São Paulo, Ática, 1996.

Fontanela de Weinberg, M. B. El espãnol bonaerense - Cuatro siglos de Evolución lingüística (1580-1980). Buenos Aires: Hachette, 1987

Frawley, W. Linguitic Semantics. Hillsdale: Erlbaun, 1992.

Freud.S. Os chistes e sua relação com o inconsciente. RJ: Imago, 1969.

Gadet, F.; Pechêux,M., La lengua de nunca acabar. México: Fondo de Cultura Económica, 1984.

García Canclini, N. Culturas Híbridas. Estrategias para entrar y salir de la modernidad. México: Grijalbo, 1990. Imaginarios urbanos. Buenos Aires: Eudeba, 1997.

Guimarães, E.R.J. (org). História e sentido na linguagem. Campinas: Pontes, 1989.

Guimarães, E. Texto e argumentação: um estudo das conjunções do português. Campinas: Pontes, 1987.

Gutiérrez, A. Pierre Boudieu: las prácticas sociales. Buenos Aires: Centro Editor de América Latina, 1994.

Hallyday, M. A K. e HASAN, R. Cohesion in english. London: Longman, 1976.

Ilari, R. e Geraldi, J.W. Semântica.São Paulo: Ática, 1985. (Série Princípios)

Isenberg, H. Cuestiones fundamentales de tipología textual, In: Lingüística del Texto. Madrid: Arco Libros, 1987.

Jitrik, N. Historia Crítica de la Literatura Argentina. La narración gana la partida. Buenos Aires: Emecé Editores, 2000.

Kempson, R. Teoria Semântica. Rio de Janeiro: Zahar, 1980.

Kerbrat-Orecchioni, K. La connotación. Buenos Aires: Hachette, 1983.

Koch, I. Argumentação e Linguagem. São Paulo: Cortez, 1984.

Referenciação: construção discursiva. Manuscrito. Campinas: UNICAMP, 1999.

Kulikowski, M.Z. Lo grotesco en el teatro de Roberto Arlt. dissertação de mestrado, Universidade de São Paulo, São Paulo, 1991. 
. Seria cômico se não fosse trágico: o discurso grotesco na narrativa de Roberto Arlt, (tese de doutorado), Universidade de São Paulo, São Paulo, 1997

Lavandera, B. Variación y significado. Buenos Aires: Hachette, 1984.

Lázaro Carreter, F. La literatura como fenómeno comunicativo. In Pragmática de la comunicación literaria. Madrid, Arco Libros, 1999.

Levinson, S. Pragmatics. Cambridge: University Press, 1983.

Lyons, J. Semantics. 2 vols. Cambridge: University Press, 1977.

Linguagem e lingüística: uma introdução. Rio de Janeiro: Guanabara, 1987.

Semântica I. Lisboa: Editorial presença/ Martins Fontes, 1980.

Maingueneau, D. Pragmática para o discurso literário. São Paulo: Martins Fontes, 1996.

Novas tendências em Análise do Discurso. Campinas, Pontes, 2ª ed, 1993.

Elementos de lingüística para o texto literário. São Paulo: Martins Fontes, 1996.

, O contexto da obra literária - Enunciação, escritor, sociedade. São Paulo: Martins

Fontes, 2001.

Manzano, M.G. El realismo expresión de inserción social. In: El protagonista niño en la literatura del siglo XX.Madrid: Narcea, 1987.

Marcuschi, L. Quando a referência é uma inferência. Manuscrito. Recife: UFPE, 2000. Análise da conversação. São Paulo: Ática, 1989.

Da fala para a escrita: atividades de retextualização. 2 ed. São Paulo, Cortez, 2001.

Marques, M.H.D. Iniciação à Semântica. Rio de Janeiro: Zahar, 1990.

Marny, J. Sociologia das histórias em quadrinhos. Porto: Civilizações, 1970.

Martins, E.J. Enunciação e diálogo. Campinas: Editora da Unicamp, 1990.

Martins, Antonio. Arthur Azevedo: A palavra e o riso. São Paulo: Perspectiva, 1988.

Martinez Bonati, F. La estructura de la obra literária. Barcelona: Seix Barral, 1972.

. El arte de escribir ficciones, Dispositio III, 7-8, pp.137-144, 1978.

. El sistema del discurso y la evolución de las formas narrativas. Dispositio V-VI, 15-16,

pp. 1-18, 1980/81.

Masiello, F. Lenguaje e ideologia. Las escuelas argentinas de vanguardia. Buenos Aires: Hachette, 1986.

Mennucci, Sud. Humor. São Paulo: Editora Piratininga,1934.

Moeschler,J. Argumentation et conversation. Éléments pour une analyse pragmatique du discourse. Paris: Hatier-Credif, 1985.

Moura, H.M.M. Significação e contexto: uma introdução às questões de semântica e pragmática. Florianópolis: Editora insular, pós-graduação em lingüística UFSC,1999.

Nomura, Masa. Linguagem funcional e literatura - Presença do cotidiano no texto literário, São Paulo: Annalume, 1993. 
Oliveira, R.P. Semântica formal. Uma breve introdução. São Paulo: Mercado de letras, 2001. Orlandi, E.P.(org), Política lingüística na América Latina, Campinas, Pontes, 1988.

A linguagem e seu funcionamento. As formas do discurso. $2^{\text {a }}$ ed. Campinas, Pontes, 1987.

. Discurso e leitura. Campinas: Editora da Unicamp, 1988.

(org), Discurso fundador - A formação do país e a construção da identidade nacional.

Campinas: Pontes, 1993.

Osakabe, H. Argumentação e discurso político. São Paulo: Kairos, 1979.

Oson, D.R.; Torrance, N. (orgs), Cultura escrita e oralidade. São Paulo: Ática, 1995.

Ong, W. (org), Oralidad y escritura. Tecnologias de la palabra. México: Fondo de Cultura Econômica, 1996.

As formas do silêncio - No movimento dos sentidos. Campinas: Editora da Unicamp, 1997.

Palmer, F.R. A Semântica. Lisboa: Edições 70, 1978.

Parret, H. Tempo, espaço e atores: A pragmática de desenvolvimento. Cadernos de Estudos Lingüísticos: IEL-UNICAMP, n 10, 1986.

. Enunciação e pragmática. Campinas: Editora da UNICAMP, 1988.

Pêcheux, M. Semântica e discurso. Campinas: Editora da UNICAMP, 1988.

M. L'analyse automatique du discours, Paris, Dunot, 1969. Trad. Bras. Pêcheux,

M. Gadet e Hak. Por uma análise automática do discurso. Campinas: Ed. Unicamp, 1990. . La lengua de nunca acabar, México DF: Fondo de Cultura Econômica, 1984.

Semântica e discurso. Uma crítica à afirmação do óbvio. Campinas: Ed. da Unicamp, 1988.

Piglia, R. Homenaje a Roberto Arlt. In: Nombre falso. Buenos Aires, Siglo XXI, 1986.

.Sobre falsificações e outras histórias. Entrevista de Ricardo Piglia a Héctor Alimonda.

Revista Novos Estudos CEBRAP, n²3, São Paulo, março de 1989.

, Respiración artificial. Buenos Aires: Pomaire, 1980.

Possenti, S. Discurso, estilo e subjetividade. São Paulo: Martins Fontes, 1988.

. Pelo humor na lingüística. D.E.L.T.A. 7, 2: 491-519.

.Os humores da língua: análises lingüísticas de piadas.Campinas: Marcado das letras, 1998.

Pretti, D. A gíria na língua falada e na escrita: uma longa história de preconceito social. In: Fala e Escrita em Questão, PRETI, D. (org), São Paulo: Humanitas, 2000. . Sociolingüística - os níveis da fala. São Paulo: Edusp, 1974. 
Mas, como devem falar as personagens literárias? Revista da ANPOLL №3, São Paulo: Humanitas, p.43-61, 1997.

A gíria e outros temas. São Paulo: T. A. Queiroz/EDUSP, 1984. (org.) Análise de textos orais. 3.ed. São Paulo: Humanitas, FFLCH, USP, 1997. O discurso oral culto. São Paulo: Humanitas, FFLCH/USP, 1997.

Língua falada: variações e confrontos. São Paulo, Humanitas, FFLCH/USP, 1998.

Puig, M. Boquitas pintadas. Buenos Aires: Edit. Sudamericana, 1969.

Propp,V. Comicidade e riso.São Paulo: Ática,1992

Récanati, F. La transparecia y la enunciación. Introducción a la Pragmática. Buenos Aires: Hachette, 1981.

Reyes, G. La pragmática lingüística. Barcelona: Montessinos, 1990.

. Polifonía Textual. La citación en el relato literario. Madrid: Gredos, 1984, . Los procedimientos de cita: estilo directo y estilo indirecto. Madrid: Arco Libros, 1995.

Los Procedimientos de cita: estilo directo y estilo indirecto. Cuadernos de lengua española. 2. ed. Madrid, Arco/Libros, S.L., 1995.

Los Procedimientos de cita: citas encubiertas y ecos. Cuadernos de lengua española.

2. ed. Madrid, Arco/Libros, S.L., 1994.

Rodrigues Lapa,M. Estilística da língua portuguesa.Rio de Janeiro: Livraria acadêmica,1975.

Rosemblat, A. Estudios sobre el Español de América. Caracas: Monte Avila Editores, 1984. . Estudios dedicados a la Argentina. Caracas: Monte Avila Editores, 1984.

Saítta, S. Prólogo de Aguafuertes Porteñas, Buenos Aires, vida cotidiana. Buenos Aires: Alianza, 1993.

Prólogo de Aguafuertes Porteñas: cultura y política, Buenos Aires: Losada, 1994.

El escritor en el bosque de ladrillos - uma biografía de Roberto Arlt. Buenos Aires:

Sudamericana, 2000.

Sarlo, B. e Altamirano, C. Literatura/Sociedad. Buenos Aires: Hachette, 1983.

Sarlo, B. El imperio de los sentimientos. Narraciones de circulación periódica en la Argentina (1917-1927). Buenos Aires: Catálogo, 1985.

. Una modernidad periférica: Buenos Aires 1920 y 1930. Buenos Aires: Nueva Visión, 1988.

Sausurre, F. Curso de Lingüística General. 6 ed. Buenos Aires: Losada, 1967.

Seale, J. Os atos de fala: um ensaio de filosofia da linguagem. Coimbra: Almedina, 1989.

Sebreli, J.J. De Buenos Aires y su gente. Buenos Aires: Centro Editor de América Latina, 1992.

Silva, T.T. Identidade e diferença - a perspectiva dos Estudos Culturais. São Paulo: Vozes, 2000.

Todorov,T. Les genres du discours. Paris: Seuil, 1978. 
Travaglia, L.C. Uma introdução ao estudo do humor na lingüística. D.E.L.T.A. 6, 1: 55-82, 1990.

Ullman, S. Semântica. Lisboa: Fundação Calouste Gubeokian, 1964.

Urbano, H. Oralidade na literatura (o caso Rubem Fonseca). São Paulo: Cortez, 2000.

Veron, E. A produção de sentido, São Paulo: Cultrix/Edusp, 1980.

Vidal, M.V.E. Introducçión a la pragmática. Barcelona: Anthropos, 1993.

Viñas, D.(director) Historia Social de la Literatura Argentina. Yrigoyen, entre Borges y Arlt (tomo VII) Directora del tomo: Graciela Montaldo, Buenos Aires, Contrapunto, 1989.

Armando Discépolo: grotesco, inmigración y fracaso. In Discépolo, Armando. Obras escogidas. Buenos Aires: Jorge Alvarez, 1969.

Zubieta, A.M., El discurso narrativo arltiano: intertextualidad, grotesco y utopía. Buenos Aires: Hachette, 1987.

\section{Bibliografia on line:}

http://www..elpais.com.es/cultura. Acesso em 10 out. 2002.

http://www.escritoras.com.es/elviralindo. Acesso em 10 mai. 2004.

\section{Bibliografia da Autora}

Lindo, Elvira. Manolito Gafotas. Madrid: Alfaguara, 1994. Novela.

Cómo molo!: (otra de Manolito Gafotas). Madrid: Alfaguara, 1995. Novela. Manolito Gafotas. Madrid: Alfaguara, 1995. Audio. Pobre Manolito. Madrid: Alfaguara, 1996. Novela. La ley de la selva. Madrid: Visor Distribuciones, S.A., 1996. Teatro. Olivia y la corte de los Reyes Magos. Madrid: SM, 1996. Cuento. Pobre Manolito. Madrid: Alfaguara, 1996. Audio. La abuela de Olivia se ha perdido. Madrid: SM, 1997. Cuento. Olivia no quiere bañarse. Madrid: SM, 1997. Cuento. Olivia no quiere ir al colegio. Madrid: SM, 1997. Cuento. Olivia no sabe perder. Madrid: SM, 1997. Cuento. Olivia y el fantasma. Madrid: SM, 1997. Cuento. Manolito Gafotas en la radio. Madrid: Alfaguara, 1997. Audio. Olivia tiene cosas que hacer. Madrid: Alfaguara, 1997. Cuento. Los trapos sucios de Manolito Gafotas. Madrid: Alfaguara, 1997. Novela. El otro barrio. Madrid: Ollero y Ramos Editores, 1998. Novela. Manolito on the road. Madrid: Alfaguara, 1998. Novela. Manolito Gafotas, 1998. Guión de cine. La primera noche de mi vida, 1998. Guión de cine. 
Yo y el imbécil. Madrid: Alfaguara, 1999. Novela.

Charanga y pandereta. Cuento. In: Cuentos solidarios. Madrid: ONCE, 1999, pp. 53-

58. Cuentos.

Bolinga. Granada: Proyecto Sur de Ediciones, 2000. Cuento.

Ataque verbal, 2000. Guión de cine.

Ser compañera. Ensayo. En: Ser mujer. Freixas, Laura (ed.) . Madrid:

Temas de Hoy, 2000, pp. 17-37. Ensayos.

Amigos del alma. Madrid: Alfaguara, 2000. Cuento.

Plenilunio.2000. Guión de cine.

El cielo abierto, 2001. Guión de cine.

Tinto de verano. Madrid: Aguilar S.A.Ediciones, 2001. Artículos.

Manolito tiene un secreto. Madrid: Alfaguara, 2002. Novela.

Algo más inesperado que la muerte. Madrid: Alfaguara, 2002. Novela.

Tinto de verano 3. Madrid: Aguilar S.A. Ediciones, 2003. Artículos.

La sorpresa del roscón, 2004. Teatro.

Una palabra tuya. Barcelona: Seix Barral, 2005. Novela. 
6 ANEXOS 


\section{Manolito Gafotas -Un cumpleñaos Feliz}

Linha 1 Mi abuelo no quería celebrar su cumpleaños.Dijo que no, que no y que no. Mi madre decía:

_ Pero papá, ocehenta años no se cumple todos los días.

Gracias a Dios - dijo mi abuelo. Sólo faltava que ese disgusto se lo dieran a uno Linha $5 \quad$ cada dos por tres.

_ i Sí abuelo! Nosotros te lo preparamos, invitas a tus amigos, compramos una piñata..._ya me lo estaba imaginando.

_ Y dentro de la piñata podéis meter pastillas para la artrosis, pastillas para la incontinencia, pastilllas para la tensión..._ mi abuelo estaba por verlo todo negro. _ Si

Linha 10 invito a mis amigos esto puede parecer un asilo. No me gusta, todo lleno de viejos, de dentaduras postizas, de juanetes, no quiero. Además, ¿ qué amigos tengo yo?

__ El abuelo de Yihad - le dije yo.

_ Le digo al abuelo de Yihad que venga a mi cumpleaños e se mea de risa. Los viejos no celebran el cumpleaños, eso no se ha visto nunca. ¿ Queréis también que apague Linha $15 \quad$ ochenta velitas?

_ ¡ Sí! - dijimos el Imbécil y yo, que a veces estamos de acuerdo.

_ Yo apago ochenta velas y me enterráis después de cumpleaños feliz.

El Imbécil y yo empezamos a cantar el cumpleaños feliz. Ese tipo de canciones siempre las cantamos a dúo y dando patadas en las patas de la mesa. Es nuestro Linha 20 estilo: la canción melódica. Mi abuelo seguía a la suyo:

_Y encima, como eres viejo, la gente sólo te regala bufandas, te llenan el armario de bufandas. Ni una corbata, ni un frasco de colonia, ni un chaquetón tres-cuartos, sólo bufandas.

_ Pues dinos lo que quieres que te regalemos - mi madre no se dá por vencida tan Linha 25 facilmente. 
_ ¡ Nada! No tengo nada que celebrar, no tengo amigos y no tengo ganas de cumplir ochenta años; lo único que tengo son bufandas de los cumpleaños anteriores.

Dicho eso mi abuelo se metió en el cuarto de baño para ponerse los dientes postizos, porque se iba a tomar el sol con el abuelo de Yihad. Mi abuelo no es de los que les Linha 30 gusta tomar el sol sin los dientes. Cogió la puerta y se fue. El Imbécil y yo nos quedamos con el cumpleaños en la boca

Yo Hasta ese momento no había conocido a nadie que no quisiera celebrar su cumpleaños. Incluso mi madre, que desde hace muchos años sólo quiere cumplir 37, lo quiere celebrar, y lo avisa muchos días antes para que mi

Linha 35 padre se acuerde y le compre un brillante, un visón o una batidora con unas cuchillas mortales, que es lo que al final acaba comprando siempre.

Después del portazo de mi abuelo pensé que mi madre se iba enfadar, porque si hay algo que a ella no le gusta en la vida es que la lleven la contraria. Así que el Imbécil y yo quedamos muy callados porque en esos momentos es muy fácil que te la cargues Linha 40 por lo que sea; como estornudes un poco fuerte se te puede caer el pelo, y no precisamente por el estornudo. Pero no, mi madre no se enfadó, seguió quitando la mesa como si tal cosa. Ya lo dijo mi padre un día del año pasado: "Ella es imprevisible".

La madre imprevisible no volvió a nombrar e cumpleaños de mi abuelo, y el famoso Linha 45 día A ( A de Abuelo) se acercaba peligrosamente. La víspera de aquél miércoles misterioso, mi madre le llamó a su cuarto y cerro la puerta. Yo me eché a temblar inmediatamente y le dije:

_ Yo no lo hice con mala intención, fue el Imbécil que saco los polvorones del mueble-bar y quería ver cómo se espanzurraban si los tirábamos por el balcón.

Linha $50 \quad$ Resultó que el que tiré yo fue el que le cayó a la Luisa en la chepa.

_ No te llamaba por eso, Manolito. 
Hay veces en la vida que me precipito a la hora de pedir disculpas, y ésta había sido una. Por primera vez en la historia no me llamaba para echarme una bronca terrorífica; me dijo que iba a celebrar el cumpleaños de mi abuelo por encima del Linha $55 \quad$ cadáver de quien fuera.

_ Pero si él no quiere...

_ Lo que él quiera o no quiera a nosostros no nos importa.

Así es mi madre, ni el Papa es capaz de hacerla cambiar los planes. Me gustaría a mi que veniera el Papa a decirle a mi madre si tiene que celebrar o no un cumpleaños.

Linha 60 Mi madre es la máxima autoridad del planeta, eso lo saben hasta los extraterreste como Paquito Medina.

Mi madre trazó un plan, un plan perfecto, el plan más perfecto que una madre ha trazado desde que existe el globo terráqueo. El plan consiste en lo seguiente:

Me iría con mi abuelo a llevar el Imbécil al médico. ¿ Qué por qué llevabos al Linha 65 Imbécil al médico? Porque tenía mocos, pero daba igual, si no hubiera sido por los mocos hubiera sido por otra cosa, porque el Imbécil no sale del médico; es el típico niño que lo coge todo. ¿ Por qué? Porque chupa toda la caca del suelo. Pero vamos a dejar esa historia. Si te contara las guarrerías que hace el Imbécil no podrías volver a comer en tu vida.

Linha 70 Mientras nosotros estabamos en el médico, mi madre iría el súper a comprar provisiones para la fastuosa merienda colosal.

A las seis de la tarde, en casa. Los invitados seríamos: mi padre, mi madre, la Luisa, el marido de la Luisa, yo y el Imbécil.

¿ Qué rollo repollo de cumpleaños! Le pregunté a mi madre si lo decía al abuelo de

Linha 75 Yihad, pero mi madre se acordó de que mi abuelo había dicho que le daba corte invitar a un amigo viejo. Pues nada, sin amigo viejo.

Antes de salir de la habitación mi madre dijo:

_ Y como me entere de que vuelves a tirar polvorones por la terraza, vas tú detrás. 
Ya sabía que era imposible entrar en la habitación de mi madre y que no te la

Linha 80 cargaras por algo. Bueno, había salido sano y salvo, sin cicatrices, no me podía quejar.

Tener un secreto tan gordo dentro de mi cerebro me ponía nervioso. Había momentos en que me parecía que no me cabía el secreto en la cabeza. Por la noche le dijo dos o tres veces a mi abuelo cuando nos acostábamos:

Linha 85 _ Abuelo, mañana es tu cumpleaños, pero jamais lo celebraremos.

Mi abuelo decía: "Pues bueno", y cerraba los ojos para dormirse. Hay veces que parece un terrible hombre impasible.

Al día siguiente le abrí las tripas a mi cerdo. Mi cerdo es una hucha de barro. Generalmente la gente rompe el cerdo cuando tiene la hucha llena; pero como yo Linha 90 nunca espero a tenerla llena y siempre quiero abrirla cuando suena dos o tres monedas porque más no aguanto, mi padre le hizo una ranura secreta en la barriga y todos tan contentos: ni yo tengo que romper la hucha ni ellos tienen que comprarme una cada domingo.

Tenía ciento cincuenta pesetas. No era mucho. La verdad es que sólo llevaba ahorrando

Linha 95 un fin de semana; eso no daba ni para comprar las bufandas esas a las que mi abuelo tenía tanto asco. Si hubiera tenido dinero me hubiera gustado comprarle una dentadura postiza. El que la que tiene se la hicieron un pelín grande y como se ponga a comer algo duro es un desastre mundial: acaba por quitarse la dentadura con el trozo de carne clavado en sus dientes postizos.

Linha 100 Me llevé las ciento cincuenta pesetas al colegio. Estaba a punto de gastarmelass en el Puesto Azul. - el Puesto Azul es el puesto de señor Mariano, que tiene todas las chucherías conocidas en uno y otro confín -, en una bolsa de canicas rojas que le han traído al señor Mariano desde China; pero me eché para atrás porque desde que el Imbécil estuvo a punto de ahogarse con mis canicas, mi madre las tiene bastante Linha 105 prohibidas. Nada de canica. Luego vi unos sobres que tiene de indios, pero es que los 
indios del señor Mariano no se tienen de pie, y a mi me gusta que se tengan de pie para hacer una montaña con el cojín y poner a los indios asomando sus plumas por detrás, como en las películas. Nada de indios. Luego vi una peonza, pero ya tenía. Un yoyó, ya tenía... \& A que no sabes lo que vi de repente, sin previo aviso?

Linha 110 Una dentadura de Drácula. No tenía dinero para una dentadura de dentista, pero si para comprarle a mi abuelo una de Drácula. Me gastaría el dinero a mi abuelo. En ese momento fui la mejor persona que he conocido en mi vida, sin exagerar. Fui como ese niño del cuento que es capaz de morir por salvar a su abuelo. Menos mal que yo no me veía en la brigación de morir, porque, la verdad, eso me lo hubiera Linha 115 pensado dos veces.

Yihad me dijo en el recreo que si la dejaba mi dentadura. Se la dejé un rato, pero le pedí que no me la chupara mucho porque se la iba a regalar a mi abuelo. Luego se la puso Paquito Medina y el Orejones, que me la dejó llena de bollo. La limpié en sus pantalones y se quedó tan blanca como antes, porque era una dentadura de primera Linha $120 \quad$ calidad.

Cuando estábamos en clase me acordé de que mi abuelo había dicho que no quería un cumpleaños con viejos, así que pensé que sería una gran idea invitar a mis amigos. Mis amigos pueden tener muchos defectos (los tienen todos), pero no son viejos. Les pasé un papel a escondidas. A mi sita no le gusta que te pongas a invitar la gente a un

Linha 125 cumpleaños mientras ella explica un rollo de los climas del mundo mundial. Pensé que a lo mejor no les apetecía venir a un cumpleaños de un abuelo... ¡ Sí, todos dijeran que sí! Mis amigos son capaces de ir al cumpleaños de Fredy Crouger con tal de tomar tarta y coca cola. Les dije que entonces se tendrían que venir todos antes a la seguridad social al llevar al Imbécil al médico. "Pues bueno, pues vamos”, dijeron.

Linha 130 
A la hora de comer felicitamos a mi abuelo y nos pusimos a ver la televisión como si no nos importara nada más en este mundo. Hay veces que lo que más nos importa en este mundo es la televisión, pero en esta ocasión estabamos disimulando.

Linha 135 Cuando llegué al colegio después de comer, Yihad estaba con su abuelo en la puerta. Yihad dijo:

_ Mi abuelo quiere saber por qué tu abuelo no le ha invitado a su cumpleaños _ Es que piensa que lo de inviterse a los cumpleaños no es de viejos.

_ Pues le va a salir el tiro por la culata porque estoy harto de invitarle al Tropezón

Linha 140 para que ahora me deje a mi tirado en la calle. $i$ A qué hora es el cumpleaños de las narices?

_ A las seis.

Estaba claro que la opinión de mi abuelo no era sagrada, todo el mundo se la saltaba a la torera. El plan perfecto trazado por mi madre quedaba así:

Linha 145 a) Mi abuelo, Yihad, yo, el Orejones, Paquito Medina y la Susana iríamos a la Seguridad Social para que el médico le viera los mocos al Imbécil. Un espetáculo sólo comparab;e a "Los Cazafantasmas".

b) El abuelo de Yihad estaría a las seis con los dientes puestos en mi casa. Allí se encontraría con mis padres, la Luisa y su marido. Mi madre se preguntaría a sí Linha 150 misma: “ ¿ Y a éste quien le ha invitado?’Pero se lo callaría porque delante de las personas de fuera siempre es muy educada, como Lady Di.

c) La fastuosa merienda colosal estaría esperándonos en la mesa.

Mi abuelo se quedó alucinado cuando vino a recogerme al colegio con el Imbécil y se encontró con que todos nos íbamos al médico con él, pero se calló. Está Linha 155 acostumbrado a que le hagamos cosas peores, como aquel día que el Orejones y yo cambiamos una aceituna negra por una cucaracha en el Tropezón. La atravesamos con su palillo de dientes y todo; la verdad es que daba el pego, pero mi abuelo sospechó que no se trataba de una aceituna como las demás cuando vio que a la 
aceituna de le movían las patas. Bueno, al fin y al cabo las cucarachas son tan típicas en el Tropezón como las aceitunas.

Linha 160 En la sala de espera de la Seguridade Social lo pasamos bestial. Es fantástico ir al médico cuando es a otro al que tienen que mirar. Patinábamos por los pasillos, bailábamos la peonza, jugábamos al churro media manga y cuando queríamos reírnos como animales le preguntábamos al Imbécil:

_ ¿ Cómo le vas a decir al médico que te suenas los mocos?

Linha 165 Y el Imbécil entraba en estado de concentración y luego se los metía para adentro. Mis amigos se partían el pecho de ver el Imbécil hacer su tontería mayor y el Imbécil se emicionó de ser el centro de la reunión, y de tanto echarse los mocos para dentro se puso rojo rojísimo que por poco se queda en el sitio por payaso. Luego pasamos todos juntos a la consulta del doctor Morales, que es el médico de todos mis amigos y Linha $170 \quad$ cura prácticamente todas las enfermedades y además, según dicen las madres, está como un tren y es cachondo. El doctor Morales es un médico de serie de televisión, en eso está de acuerdo todo el Carabanchel. Nos subimos todos a la camilla con el Imbécil; todo paracía ir muy bien hasta que Yihad empezó a tirarnos camilla abajo; entonces el simpático doctor Morales, ese doctor de serie de televisión, nos dijo que Linha 175 se no teníamos nada que hacer en nuestra casa. El Orejones, que le ha tocado el papel en esta vida de meter la pata, dijo:

_Sí, tenemos que celebrar el cumpleaños de...

No pudo terminar su frase asesina porque se encontró con que cuatro codos se le habían metido en la boca. Eran los nuestros.

Linha 180 El caso es que el diagnóstico del médico nos tranquilizó mucho: los mocos de Imbécil no eran graves, eran asquerosos. De repente mi di cuenta de que ya eran las seis y cuarto, cogimos todos a mi abuelo tirándole del chaquetón y lo llevamos casi corriendo hasta mi casa. De vez en cuando nos daba la risa nerviosa, porque la emoción de llevar a un abuelo a un cumpleaños sorpresa sólo se puede comparar a las 
Linha 185 cataratas del Niágara o al cañon del colorado; lo demás en la vida no es tan emocionante.

Cuando llamamos al telefonillo de mi casa salió la voz de mi madre diciendo:

_ Manolito, dile al abuelo que se acerque al Tropezón a traer una botella de casera para la cena.

Linha 190 Mi abuelo, que lo estaba oyendo se dio media vuelta para ir al Tropezón; a él le encanta que mi madre le mande al bar a por alguna cosa que se le ha olvidado. Lo que ocurre es que luego a él se le olvida despegarse de la barra para volver a casa.

Subí con mis amigos a casa. Mi madre abrió la puerta y se quedó mirando: $-i \mathrm{Y}$ todos estos?

Linha 195 Con mis amigos no se corta ni un pelo; los trata igual de mal como si fuera sus hijos.

_ Como el abuelo no quería un cumpleaños lleno de viejos le he traído a mis amigos. _ No importa - esto lo decía mi madre con tono sospechoso-; tenemos niños, viejos... Es un cumpleaños para todos los públicos.

Linha 200 Era verdad. Al abuelo de Yihad se le había ocurrido traerse a cuatro abuelos más de los que van a jugar al chinchón al Club del Jubilado. También estaba la Luisa, pero eso no es ninguna novedad; la Luisa siempre está en mi casa, menos a la hora de dormir, que se baja con su marido por si a Bernebé se le desloca el peluquín mientras ronca. Mi madre nos colocó al rededor de la mesa. No se podía tocar ni un panchito

Linha 205 porque estaban contados y mi madre se pone nerviosas cuando hay mucha gente y poca comida. Todo estaba preparado para cantar el Cumpleaños Feliz cuando el abuelo asomara por la puerta.

Oímos la llave y nos pusimos a cantar como locos y a comer al mismo tiempo. Antes de que llegara al salón, Yihad había acabado con las patatas y su vaso de coca cola; y Linha 210 eso que mi casa, como dice mi madre, es una caja de cerillas y uno llega pronto a todas las habitaciones. Pero el que entró no era mi abuelo, era el marido de la Luisa 
que venía con más víveres; tres botellas de vino para los abuelos. Nos llevamos un cortazo y un tortazo. Mi madre dijo que al que volviera a abalanzar sobre la comida le daba un bocadillo para que se lo comiera solo y triste en el parque de Ahorcado. Es Linha $215 \quad$ una madre sin compasión.

El marido de la Luisa tomó posiciones en el corro que formábamos alrededor de la mesa. Volvió a sonar la llave en la puerta y repetimos nuestro Cumpleaños Feliz con la misma energía poderosa de antes. Yihad se seguió metiendo comida en la boca creyendo que mi madre no se daba cuenta, lo que pasa es que a veces decide hacerse

Linha 220 la sueca. Si yo fuera Dios la contrataría: ella es capaz de tener sus ojos en todas las partes. Es del tipo de madre camaleónica.

Otro corte como un castillo: era mi padre que venía con un queso manchego que había comprado en un bar de la carretera que pillaba de camino. Mi madre cortó unos tacos de queso y los repartió para que matáramos el hambre mientras llegaba el Linha 225 protagonista de nuestra historia verídica.

Nos volvimos a colocar en nuestras posiciones, comíamos el queso sin hacer ruido para que al entrar mi abuelo no se percatara que su casa estaba invadida por miles de personas. Pasó un rato..., y al tercer rato los abuelos empezaron a pedir sillas porque, la verdad, mi abuelo se estaba poniendo un poco pesado.

Linha 230 Mi madre decidió llamar al Tropezón, ella tiene el teléfono del bar porque tiene que rescatar muchas veces a mi padre y a mi abuelo de las garras de algún pulpo que hay en la vitrina.

Se puso el dueño, el señor Ezequiel, y le dijo a mi madre:

_ Pues sí, aquí está don Nicolás, dice que nadie le ha regalado ni una mísera bufanda.

Linha $235 \quad$ Mi madre contestó:

_ Dígale a mi padre que suba inmediatamente.

Y mi abuelo subió inmediatamente porque cuando mi madre dice inmediatamente no hay terrícola que se atreva a subir dentro de un rato. 
La puerta del salón se abrió y empezamos a cantar nuestro Compleaños Feliz. Lo

Linha 240 haciamos mejor que los niños cantores del Papa; si el Papa nos conociera nos contrataría “ipso facto”. Tenías que haber visto la cara que puso mi abuelo cuando vio que Españo entera estaba en el salón de mi casa. Detrás de él entró don Ezequiel con una fuente de gambas y otra de berberechos, y todo el mundo lo recibió con un gran aplauso. Creo que las fuentes no duraran ni un cincuenta milésimas de segundo. Los abuelos se comían las Linha 245 gambaas con cáscara y los berberechos a puñados. La gente empezó a sacar los regalos. El regalo del abuelo de Yihad fue una bufanda a cuadros que a mi abuelo le encantó; los otros abuelos le regalaron dos bufandas, una negra y otra verde que a mi abuelo les parecieron preciosas, la Luisa le había comprado un a bufanda "made in Italia"que a todos nos pareció muy elegante, mi madre le regaló un foulard, que es como una

Linha 250 bufanda, pero de tela, "para que parezcas más joven” y todo el mundo estuvo de acuerdo en que parecía diez años más joven; mis amigos le prometieron su bufanda para el cumpleaños que viene; y el Imbécil y yo le dimos la dentadura de Drácula, que fue un exitazo. Mis abuelo se quitó los dientes postizos de siempre y se puso la del señor Mariano. Le estaba perfecta. Mi abuelo dijo que sería la dentadura de los domingos.

Linha 255 Molaba mi abuelo de vampiro: el famoso vampiro del Carabanchel, ése es mi abuelo. No quedó nada. Se acabó el vino, la casera, las cocacolas. Bajaron a por más, se siguió acabando. Los viejos hacían cola todo el rato para mear; cuando le tocaba al último de la fila, ya tenía ganas otra vez el primero.

Mi madre sacó la tarta, pero la tarta no se veía: quedaba oculta por ochenta velas. Mi Linha 260 madre bajó las persianas para que el salón quedara iluminado sólo con la luz de las velas. El Imbécil se puso a llorar porque decía que le daban miedo la cara de los viejos alrededor de la tarta. A mi abuelo le sobresalían lo colmillos a los dos lados de la boca. Estaba realmente espectral, sólo le faltaban unas gotas de sangre por la barbilla. Mi madre nos dijo que apagáramos los niños las velas. Gritaron: ; Una, dos 
y tres!, pero Yihad se nos adelantó y las apagó él casi todas. Hasta en las fiestas de tu abuelo siempre hay un tío que te fastidia la vida. Mi madre dijo que en los cumpleaños no hay que pelearse, así que tuve que aguantarme, como siempre. Ahora Linha 270 que lo pienso paso de soplar velas, qué idiotez. Mientras partían la tarta cantamos Es un muchacho excelente, y a mi abuelo se le cayeron dos o tres lágrimas, como siempre que se brinda, que el reloj de la Puerta del Sol toca para las uvas o que sale gente en la televisión muriéndose en la guerra. El abuelo de Yihad dijo que mi abuelo tenía que decir unas palavras. Mi abuelo decía que no, que no y que no, pero se hizo

Linha 275 otro coro del Papa para gritar: “ ¿Que hable, que hable!” Entonces mi abuelo dio la noticia, la mejor noticia de la temporada teniendo en cuenta que el real Madrid como siga así no va a ganar la Liga. Mi abuelo anunció:

_ Siempre he dicho que pensaba morirme en 1999, unos días antes de que acabara el siglo XX, bueno, pues he pensado que voy a probar dos o tres años del siglo XXI.

Linha 280 El público aplaudió. Mi madre le pedió a los abuelos que bajaran con nosotros al parque del ahorcado mientras ella recogía.

El suelo estaba lleno de patatas y de cocacola. Seguro que por la noche estaría otra vez brillante como un espejo, porque mi madre es como esas madres de lo anuncios, pero con la casa mucho más pequeña.

Linha 285 Bajamos al parque del Ahorcado. Al rato empezaron a venir las madres para recoger a mis amigos. El Imbécil, mi abuelo y yo nos quedamos los últimos. Ya no teníamos que llevar la odiosa trenca y los días eran mucho más largos. Ese cambio meteorológico ocurre todos los años en Carabanchel el 14 de abril, el día del cumpleaños de mi abuelo. No me preguntes por qué. Científicos de todo el mundo Linha 290 han intentado encontrar una explicación a este fenómeno y no la han encontrado, pero han tenido que admitir que el verano en Carabanchel empieza el día en que Nicolás cumple años. 
Mi abuelo se había bajado todas sus bufandas en una bolsa para mirarlas de vez en cuando. Yo hago lo mismo con mis regalos de Reyes: me los bajo todos al parque del Ahorcado para que no se separen de mí todo el día. Estabamos sentados en el único

Linha 295 banco del parque del Ahorcado que no está roto; es el banco donde se echan la siesta por la mañana todos nuestros abuelos. El que se había dormido era el Imbécil, tenía la cabeza apoyada en mi abuelo y los pies en mí. Siempre me toca soportar lo peor de las personas. El Imbécil es muy pequeño, pero ya le huelen los pies; en eso ha salido a mi padre. Yo también he salido a mi padre: en las gafas y en el nombre.

Linha $300 \quad$ Yo estaba muy contento porque ya quedaba mucho menos para que se acabara la escuela y la despiadada sita Asunción desaparecería por unos meses. Llegarían los meses de verano y mi abuelo, el Imbécil y yo nos bajaríamos al parque hasta que se hiciera de noche, sin chaqueta, sin abrigo, sin nada. Las madres nos llamarían por las terrazas cuando las salchichas estuvieran hechas y todo el mundo en mi barrio se Linha 305 acostaría mucho más tarde. Molaba cien kilos que llegara el verano.

Mi abuelo me señaló el sol tan rojo a punto de desaparecer detrás del árbol del Ahorcado. Mi abuelo dice que el suelo del Carabanchel es horroroso, pero que el cielo es de los más bonitos del mundo, tan bonito como las pirámides del Egipto o el rascacielos de King Kong. Es la octava maravilla del mundo mundial.

Linha 310 Todo estaba tan quieto como en una película que echaron en la tele en la que un abuelo y un niño se quedaban los últimos en el cementerio después del entierro de uno que era negro. Pero esto era mucho mejor porque en la película de mi vida no habría ningún muerto de momento, me lo había prometido mi abuelo.

No te lo vas a creer, pero creo que fue la tarde más feliz de mi existencia en el planeta Linha 315 Tierra. 


\section{Entrevista: Elvira Lindo por Luiz García}

Elvira Lindo. Cádiz 1962. Vive en Madrid desde los doce años. En 1987, empezó a trabajar en la radio como locutora y acabó especializándose en guiones. Fue entonces cuando nació Manolito Gafotas, el protagonista de sus libros. Elvira Lindo ha escrito también guiones para la televisión, para el cine, y ha estrenado en teatro Ley de la selva 1994, una comedia de costumbres. Manolito Gafotas ha sido llevado al cine en dos ocasiones con desigual aceptación. Títulos de la autora: Pobre Manolito 1995, Olivia y las carta a los Reyes Magos 1996, Manolito Catrollos 1996, Manolito Gafotas en la radio (grabación sonora) 1997, Los trapos sucios de Manolito Gafotas 1997., Manolito On the Road 1998, Como Molo: otra de Manolito Gafotas 1998, Todo Manolito 2000, Amigos del Alma 2000, , Yo y el Imbecil 2000, Manolito Gafotas 2000, ¿Quién Mato a Harry? 2000 (Juan Bonilla, Felipe Benítez Reyes, Elvira Lindo), El otro barrio 2000, Tinto de verano 2001.

Introducción.- ¿Es Elvira Lindo la mujer de Antonio Muñoz Molina o Antonio Muñoz Molina el marido de Elvira Lindo. Es posible que la terna resulte un tanto pueril para muchos. Para otros no es mas que un reflejo de las nuevas parejas literarias que han nacido en nuestro país, de las que las más famosas y menos populares son Elvira Lindo \& Muñoz Molina y Almudena Grandes y Luis García Montero. Pero si las comparaciones son odiosas, conviene recordar que Elvira Lindo fue monaguillo antes que monje, o lo que es lo mismo, se curtió primero en el competitivo campo de la radio. Allí nació Manolito Gafotas, uno de los más entrañables personajes de ficción de los últimos años. Allí lo vio crecer y allí, finalmente, se le independizó y cobró vida literaria. Se puede decir que a partir de entonces Elvira Lindo perdió el control de su creación. Ya nunca más podría dominarlo a su antojo. Aunque por otra parte, nosotros, los lectores, habríamos de ganar a la que pasa por marcar las pautas de la literatura juvenil de los últimos años.

Luis García.- $\quad$ Elvira Lindo \& Manolito gafotas. ¿Qué fue primero, el huevo o la gallina?.

Elvira Lindo.- Primero fui yo. En realidad, Manolito era uno de los muchos personajes que yo hacía en la radio, el caso es que lo repetí más veces porque gustaba más y porque yo siempre me divertí mucho haciéndolo, 
pero mi vida en la radio es mucho más intensa. No sólo he interpretado a Manolito, he presentado también programas en Radio 3, en Radio Cadena, y he trabajado en todos los ámbitos posibles, desde la información sin más hasta la presentación de programas musicales o culturales. Trabajé en la radio muchos años, así que hubiera sido absurdo que sólo me hubiera dedicado a hacer un personaje, en realidad, Manolito era una de las muchas cosas que hacía. Lo que ocurrió es que cuando dejé Radio Nacional, me llamaron de la cadena SER para hacer solamente Manolito los fines de semana, y a mucha gente que no me conocía de mi trabajo anterior debió parecerle que mi única relación con la radio era hacer un personaje.

L.G.- ¿Cómo nació el personaje?. ¿Se inspiró en alguien en particular?.

E.L.- $\quad$ Ya digo, yo presentaba programas, hacía entrevistas, pero siempre me gustó escribir guiones, cuentos para la radio. A veces los interpretaba yo y otras buscaba a locutores para que me pusieran las voces. En el caso de Manolito, fue muy simple: un día debí escribir el monólogo de un niño, y no debí encontrar a nadie que me prestara la voz y la puse yo. A todo el mundo le hizo gracia y lo repetí al día siguiente. Manolito nació por la repetición.

L.G.- $\quad$ No abundan los casos en los que un personaje de Radio, que nació más para ser escuchado que leído, haya dado el salto a la literatura. ¿Sintió vértigo en sus comienzos?.

E.L.- $\quad$ No sentí vértigo en el sentido de que cuando empecé a escribir el libro Manolito era ya un personaje muy sólido en mi cabeza, es como si estuviera escribiendo un libro sobre un niño que conocía a la perfección puesto que llevaba interpretándolo y escribiendo guiones para "él" muchos años. Pero sí que sentí miedo por el hecho de estar casada con un escritor muy conocido y que eso se pudiera interpretar como algo poco serio. Debo decir que la gente cercana, fundamentalmente mi marido, me animaron a desarrollar 
una vocación literaria que yo tenía de siempre y que sólo había podido ejercer como guionista.

L.G.-

Tengo un amigo que siempre la escuchaba, pero que nunca la ha leído, lo que demuestra que tiene muchos más seguidores en la sombra esperando quizás su retorno a las ondas. ¿Será posible algún día?. ¿Volveremos a oír la voz de Manolito Gafotas?.

E.L.-

A mí me gustaría que esos oyentes que me escuchaban en la radio dieran el paso a los libros porque aunque Manolito naciera en la radio, para mí, la idea de Manolito siempre fue una idea escrita, nunca me ha gustado interpretarlo improvisando, he seguido todos estos años un guión y lo he seguido con bastante rigor, aunque a la gente le pareciera que todo era muy natural. No era en absoluto natural: yo me ponía el día anterior a escribir un guión que me costaba bastante trabajo y al día siguiente lo interpretaba con mis cinco sentidos para que conseguir toda la gracia, la naturalidad posibles. En cuanto a mi vuelta..., no sé, en realidad lo dejé porque estaba cansada, casi físicamente, no por ninguna otra cosa. Llevaba trabajando todos los fines de semana durante cinco años y eso agota. Pero también me da pena pensar que nunca lo volveré a interpretar. Tengo serias dudas con todo esto.

L.G.-

¿Se los imaginaba a él y a sus amigos El Imbécil, Susanita bragas sucias, etc, como al final fueron en la película?. ¿Le gustó la versión de Manolito Gafotas?.

E.L.- $\quad$ Era difícil de imaginar para mí, pero apoyé la primera película, la que hizo Miguel Albaladejo porque él se metió en el proyecto con muchísimo cariño y respeto por el personaje, y creo que la película es el resultado de mis textos y también de la visión propia de Miguel, es una película muy tierna. En cuanto a la segunda, no me identifico en absoluto, no he pasado de los diez minutos y me pareció espantosa. Parece que hay gente que cuando hace cine para 
que lo puedan ver niños baja el nivel o pierde el respeto hacia el espectador.

L.G.-

¿Le molesta que la comparen con J.K. Rowling?.

E.L.- $\quad$ No, pero creo que en la comparación hay cierto desconocimiento porque en realidad en lo único que nos parecemos es en que hemos escrito libros para niños y en que, al menos en España, las dos hemos sido un best seller. No hay más, porque mi forma de escribir no tiene mucho que ver con la suya, pero cuando se habla de literatura infantil todo se simplifica. Imagínate que a dos autores de adultos los compararan continuamente por el simple hecho de que los dos vendieran muchos libros, realmente la comparación es escasamente literaria, es puramente económica, y me parece lamentable que sólo se hagan comparación económicas en la literatura para niños porque se desconoce el resto o porque no se tienen más elementos de juicio. Mis libros para niños se parece mucho más a los de Roahl Dahl, que por cierto, es un clásico, que es lo que deseamos ser todos. Yo preferiría saber que mis libros se siguen vendiendo dentro de diez años al hecho de vender ahora muchísimos y que luego el fuego se apague.

L.G.-

Soy de la opinión de que si bien nosotros nos criamos y crecimos bajo la sombra de Mafalda y Snoopy, e incluso de El Pequeño Nicolás, nuestros hijos lo hacen bajo la de Harry Potter y Manolito Gafotas. ¿Tiene usted esa sensación?.

E.L.- $\quad$ Es posible. Ojalá. Y es una buena mezcla porque la señora Rowling se dedica al mundo de la fantasía y yo el mundo de la realidad, son dos buenos contrapuntos para una imaginación infantil. Puedo decir ya que hay chicos estudiando su carrera universitaria que tienen como recuerdos de sus lecturas infantiles a Manolito Gafotas. Eso me hace muy feliz. 
L.G.-

Se han hecho muchas lecturas, muchas interpretaciones de su personaje. Pero sin duda una de las que más me ha llamado la atención, ha sido la importancia que desde algunos círculos se le dio a la figura del abuelo en sus libros. ¿Qué hay de cierto en ello?.

E.L.-

Bueno, la figura del abuelo es muy importante en el libro, porque en este libro para niños son muy importantes los adultos, algo que a veces se me ha criticado por la idea de que en los libros para niños deben aparecer ante todo niños. En realidad el abuelo es un poco la mezcla de todas las personas mayores que convivieron conmigo durante la infancia, tíos, tías mucho mayores que mis padres. Yo los adoraba, sobre todo a mi tía Concha, en realidad, a veces el abuelo, ahora que lo pienso, es mi tía Concha.

L.G.- $\quad$ Porque tengo entendido que incluso le llegaron a dar un premio en Francia por el tratamiento que sobre dicho personaje y su relación con su entorno familiar hace en sus libros.

E.L.- $\quad$ No he llegado a ganarlo, he estado propuesta varias veces para ese premio.

L.G.- $\quad$ Pero el abuelo no deja de ser una abuelito convencional, con sus manías y sus rarezas, pero al fin y al cabo como lo son todos aquellos que ya han sobrepasado un cierto umbral.

E.L.- $\quad$ Bueno, no estoy de acuerdo, hay abuelos que pueden tener muy mala leche, además este es un abuelo que vive con ellos, un abuelo del pueblo que se ha venido a la ciudad, eso cada vez es menos común. No digo que sea un personaje muy original, pero yo no pretendo que mis personajes sean originales, sino que sean creíbles, que sean sólidos y que a mí me gusten. No tengo porque hacer un abuelo que pilote coches de fórmula 1.

L.G.- $\quad$ Pasa usted por ser una observadora un tanto cáustica de la vida diaria. Los artículos de sus Tinto de verano en El País así lo atestiguan. ¿Ha recibido muchas amenazas por ellos?. 
Amenazas, no. He recibido muchas felicitaciones y también el escándalo de gente que no los ha entendido. A mí me choca que la gente piense que hay algo"moralmente" reprochable en ellos, porque son, ante todo, artículos irónicos, pero creo que resulta extravagante que sea la mujer la que haga humor sobre la vida diaria, sobre el marido y los hijos. De verdad que pienso que ese ha sido el punto que más ha molestado a determinada gente que, por otra parte, no tiene mucho sentido del humor. En España sabemos abundan los chistosos de barra de bar pero hay poco humor escrito y el lector no está muy acostumbrado a eso. Pero debo decir que quitando ese tipo de lector, en el fondo muy puritano, tengo muchos seguidores. No me puedo quejar. Y a mí me gusta ser extravagante, lo soy en mi forma de ser, en mi vida diaria, y eso es lo que se trasluce en los artículos.

L.G.- ¿Qué le dice "su santo" cuando la lee?. ¿Le reprocha ese sarcasmo que utiliza en los artículos?. Esa frivolización de la intelectualidad.

E.L.- $\quad$ No, a mi marido le encanta los artículos, él es el primero que los lee, por supuesto, y le hacen muy feliz, se ríe. Tengo mucha suerte porque para mí su juicio es importantísimo, y el que a él le gusten me da mucha seguridad. Tiene mucho sentido del humor, y le encanta que yo sea descarada.

L.G.- $\quad$ ¿Se ha acostumbrado a ser la mujer de Muñoz Molina, o comienza él a ser él el marido de Elvira Lindo?.

E.L.- $\quad$ En nuestra vida normal de todos los días no pensamos muchos en quiénes somos públicamente, de verdad, no es algo que esté en nuestras conversaciones. No hay competencia entre nosotros. Nuestros apellidos desaparecen. $Y$ con respecto a ser Señora-de, bueno, estoy casada, claro, y con un escritor muy conocido, pero siempre quise tener mi sitio en el mundo porque he trabajado desde los dieciocho años, ¿cómo voy a conformarme con ser la sombra de alguien? Me gusta trabajar, estar en el mundo, que se me tenga en 
cuenta, y no me refiero a un nivel público sino a todos los niveles. No soy el prototipo de señora de artista.

L.G.-

¿Cómo es la vida diaria con Antonio?. Quiero decir... en lo literario, por supuesto.

E.L.- Compartimos muchas cosas de nuestro trabajo: opiniones, correcciones, dudas...Nos contamos los proyectos. Tenemos bastante camaradería en lo profesional porque hay mucha confianza en la opinión del otro.

L.G.- $\quad$ ¿Y en lo personal?. ¿Surgen las inevitables rencillas, los celos... profesionales?.

E.L.-

Ya le digo: no hay competencia. Pero cuando las personas se entienden y se llevan bien, ya lo saben los periodistas, no hay noticia. De acuerdo, somos una pareja que no se dedica a algo convencional y que tienen cierta proyección pública; desde fuera, eso puede resultar chocante pero nosotros no pensamos nada en ello, nos dedicamos a intentar disfrutar de la vida. Eso sí que puedo confesarlo: intentamos disfrutar de la vida al máximo.

L.G.- $\quad$ ¿Se corrigen mutuamente los textos?

E.L.- $\quad$ Por supuesto.

L.G.- ¿ ¿Por qué se han ido a vivir a Nueva York?

E.L.- $\quad$ Porque nos gusta pasar un tiempo fuera todos los años, lo que ocurre es que este año se ha enterado todo el mundo por lo que ha sucedido pero es algo que solemos hacer. Nos gusta salir de vez en cuando de este mundo a veces fácil y a veces asfixiante de las figuras públicas para convertirnos en anónimos. Es algo que enseña mucho, y mirar a tu país desde fuera también enseña. 
L.G.- $\quad$ Una pregunta fuera del guión. ¿Cómo vivieron el atentado de las Torres Gemelas?. Porque si había unos enviados de excepción en la gran manzana eran ustedes.

E.L.- Lo vivimos con angustia, como todo el mundo allí. Se vivió con angustia en todo el mundo, pero claro, allí la angustia se multiplicaba porque no se sabía si la cosa iba a continuar. Y siendo una ciudad a la que tenemos especial cariño y en la que hemos estado tantas veces lo vivimos con pena, con tristeza porque es un palo muy grande para una ciudad el perder cinco mil almas. Hemos disfrutado mucho de nuestra estancia allí pero no cabe duda que todo se ha visto empañado por estos momentos tan difíciles que está viviendo el mundo.

L.G.- ¿Qué está preparando en estos momentos Elvira Lindo? ¿Para cuando una nueva entrega de las correrías de Manolito Gafotas?.

E.L.- $\quad$ Estoy escribiendo una novela, así que ahora no pienso en Manolito. No puedo tener la cabeza en tantos sitios a la vez, procuro concentrarme sólo en mi novela. Poner toda mi energía en que me salga como yo he soñado. 